\title{
Cold sintering of ceramics and glasses: A review
}

\author{
Cekdar Vakifahmetoglu*, Levent Karacasulu \\ Department of Materials Science and Engineering, Izmir Institute of Technology, 35430 Urla, Izmir, Turkey
}

\section{A R T I C L E I N F O}

\section{Keywords:}

Sintering

Low temperature densification

Cold sintering

Hydrothermal sintering

Reactive hydrothermal liquid-phase

densification

\begin{abstract}
A B S T R A C T
Traditionally ceramic artifacts are processed at high temperatures $\left(>1000{ }^{\circ} \mathrm{C}\right.$ ) by classical sintering techniques such as solid state, liquid phase and pressure-assisted sintering. Recently, inspired from the geology, novel sintering approaches that allow the densification of ceramic components at relatively low temperatures $\leq 400{ }^{\circ} \mathrm{C}$ have been proposed. While initial efforts for such low temperature densification concept were developed in the mid-70s, the topic has become increasingly prominent in the last decade. Currently, these low temperature methods can be classified into four main groups: (i) hydrothermal reaction sintering (HRS), (ii) hydrothermal hot pressing (HHP), (iii) pressure-assisted densification techniques: room-temperature densification (RTD), cold sintering (CS), warm press (WP), and finally no-pressure assisted method called (iv) reactive hydrothermal liquid phase densification (rHLPD). Above named techniques are commonly assisted by an aqueous solution used as either reactant or transient liquid phase to assist densification. Starting from the background in traditional sintering processes, this review aims to explore in depth the existing literature about low temperature densification approaches along with their advantages \& disadvantages, and probable application areas.
\end{abstract}

\section{Sintering overview}

The term sintering basically defines a process of bonding, densification and/or recrystallization of powder compacts, i.e. a treatment in which a green-body is converted to a stronger monolith [1-4]. While ceramic artifacts found in archaeological sites indicate sintering practice even in the upper Paleolithic era, i.e. specifically Gravettian around 26,000 years ago [5], the first steps towards establishing sintering theory and practice were only developed starting from early 1900 s $[2,6]$. One of the first scientific works was published by Ferguson J. B. in $1918[7,8]$. In the late 1940s, the main qualitative analysis on sintering were postulated by Rhines [9] for solid state and Lenel [10] for liquid phase sintering. Then, the quantitative models for sintering were built by Frenkel [11] in 1945 and Kuczynski [12] in 1949. Lenel [10], Kingery and Berg [13] and later on Coble, contributed to the sintering theory for ceramic materials, published series of remarkable works [3,14-17].

For more details on sintering, the interested reader is referred the published works of German R.M. [3,6,18], and a recent review by Bordia et al. [8]. Here, only a brief overview will be mentioned. There must be a net reduction in the free energy between the two particles to be sintered on a local scale towards thermodynamic minimum for sintering to take place $[2,19]$. At early stages of sintering the driving force to minimize the free energy is related to the annihilation of surface curvatures. Mass flow is a function of chemical potential gradient of the surface, and this is proportional to the surface curvature [20]. Later on, the dominant driving force turns to be the interfacial energy reduction by the replacement of higher energy interfaces with the lower energy ones via pore reduction and grain growth. The densification driving forces can be enhanced with the externally applied pressure which results in the amplified stress levels on the initial small particle contacts. Over time the rate decreases, and in the late stages of sintering diffusional events which are related to the processing temperature, controls the densification as in the case for methods such as hot pressing (HP) or hot isostatic pressing (HIP) [21]. A much stronger driving force can be obtained, in principle, from a chemical reaction during sintering which can provide significant free energy reduction. However, because the microstructural evolution is difficult to control, it is barely ever considered to achieve densification [2,17].

Conventional sintering is generally categorized in three basic forms: (i) solid-state, (ii) liquid phase, and (iii) viscous sintering. Typically, when a green body is densified at temperatures not causing the liquid formation, the process is called solid state sintering (SSS). The particles start to join each other accompanied by the reduction in the porosity because of the atomic diffusion [22]. Mass transport in SSS occurs through surface (non-densifying) and bulk (densifying) transport. The former one produces neck growth by mass flow from surface sources, i.e. transport originating and terminating at the surface by evaporation-

\footnotetext{
* Corresponding author.

E-mail addresses: cekdarvakifahmetoglu@iyte.edu.tr, cvahmetoglu@gmail.com (C. Vakifahmetoglu).
} 
condensation, surface diffusion and volume (lattice) diffusion, resulting in no densification or shrinkage. To attain densification, internal mass sources must be transferred to the neck, i.e. diffusion from interior to pore by grain boundary diffusion, volume and plastic flow which predominantly observed in metals $[2,3,17,18]$. While non-densifying mechanisms do not directly contribute to densification process. These mechanisms reduce the surface curvature and consequently lower the rate [2]. In another words; for kinetic considerations both mechanisms should be considered when sintering in solid state is practiced.

In liquid phase sintering (LPS) the solid mixture carries typically few volume percent of liquid (depending on the system but generally below 15 vol\% [21]) at the sintering temperature. Densification in LPS can occur both by liquid flow akin to viscous flow and mass transport similar to the ones observed for SSS [8]. In the classical LPS theory the chemical reaction between the solid and the liquid phase is assumed to play a little role. The process is considered to follow three successive stages: (i) rearrangement, (ii) solution-precipitation, (iii) elimination of porosity [18,23-25]. The initial stage of LPS is liquid redistribution and particle rearrangement to reach ideal packing due to capillary gradients. In the following solution-precipitation stage, solids dissolve at the higher chemical potential sites, and precipitate on the sites with lower chemical potential [26]. The densification of the skeletal network surrounded by liquid phase controls the final stage. It should be noted that several important parameters such as the wettability, liquid volume, viscosity and solubility of solid and liquid, etc. influences LPS [24].

Compared to that in LPS, when sufficiently large liquid volume (25-30 vol\%) is used the process is called as viscous flow (vitrification for clay based materials) sintering as seen in the traditional clay based ceramic manufacturing where above $50 \mathrm{vol} \%$ of liquid is practiced commonly (e.g. porcelains). Such densification process is believed to occur through pore filling by viscous flow $[22,27]$. In transient liquid phase sintering, a liquid phase forms in the body at an early stage of sintering but it disappears in the course of sintering progresses, leaving no glassy phase on the grain boundaries, contrary to the other LPS techniques in which the liquid phase may persist over the course of firing. While the control on the microstructure is challenging, the process results in components having higher suitability for high temperature applications than those produced by other LPS processes $[17,19]$.

Densification of amorphous powder compacts occurs by material flow over the entire volume, i.e. viscous (flow) sintering. Different than SSS and LPS, for viscous sintering the geometric variables such as particle and pore size \& shape are not important while the relative density of the green-body is of great importance [8,22]. Besides, as known the sintering of glass may be impeded by crystallization. However by enhancing the heating rate, it is still possible to sinter the glass to full density before the onset of crystallization [28]. While crystallization depends on nucleation and growth, glass sintering is merely related to viscous flows. Because for nucleation not only rheological properties but also the amount of undercooling is critical, a faster heating rate gives an advantage to sintering process [28,29].

In addition to the pressureless sintering, there are pressure-assisted sintering techniques (HP, HIP, sinter/hot and gas forging, etc., commonly all are non-economical and sample size is limited). In such techniques, both externally applied (uniaxial, hydrostatic or triaxial hybrid) pressure and surface curvature may contribute for densification. During the initial stage, external pressure is amplified at the particle contacts. At these points effective pressure is much higher than that of the applied one, and causes a stress level higher than the yield strength of the material, i.e. plastic flow and grain re-arrangements (particle centers get closer) are active. When particle coordination increases, the stress at the local contact points falls below yielding. For most materials, at low temperatures the yield strength is high and for this reason elevated (in the range of GPa) consolidation pressures is needed to attain full density. This is beneficial to avoid grain growth and obtain fine grained highly dense microstructures but there are equipment limitations to reach such pressures. As a remedy, heating (thermal softening) is applied to decrease required pressure levels since diffusion is enhanced at elevated temperatures $[17,21,30]$.

The pressure during heating imposes complex stress states on the particles. When stress and diffusion (atomic motion) is combined, creep (a time-dependent deformation) may occur at stress levels below yielding, and in pressure-assisted sintering this is the most dominant densification mechanism. Atomic transport can proceed by (i) Coble creep [31-33], i.e. grain boundary diffusion, (note that in geology if liquid/solution trapped at the grain boundaries assist densification, the mechanism is called pressure-solution creep via dissolution-precipitation process [30,34-36]), and (ii) Nabarro-Herring creep [37] i.e. volume diffusion controlled creep [38].

Traditional sintering practices have limits to control the microstructure effectively. For example, it is difficult to produce nanostructured materials because of the grain growth in the final stage of sintering [8]. Some of the contemporary techniques address this problem: sintering under the effect of electrical current and pressure, i.e. spark plasma sintering (SPS) [39-41], sintering by microwave [42-44], sintering by electrical joule heating, i.e. flash sintering allowing very rapid densification ( $<60 \mathrm{~s}$ ) [45], and selective laser sintering [46].

\section{Low temperature densification methods}

Several sintering examples can be found in nature; ice sinters akin to pressure-assisted sintering and transforms into a glacier [47-49]. Another one is lithification in which loose particles become sedimentary rock. Lithification is a chemical process that enables densification by reducing porosity via compression (pressure) and cementation [50]. Thermal sintering processes also be seen but generally at low shear stresses, see Fig. 1. Instead, in natural shock sintering initial temperatures may be low but pressure levels are high, i.e. cold plastic flow processes. Industrially, reaching to few gigapascals of pressure is not an easy task, while in nature much higher pressures occur. Implications on kinetics are important as well, since in industrial manufacturing the processes are required to be finalized as fast as possible which may take significantly longer in nature (hundreds of years [50]).

Inspired from the above mentioned natural processes, scientists have put efforts to produce dense and strong ceramic and glass compositions at low temperatures $<\sim 400{ }^{\circ} \mathrm{C}$, recently referred to as cold sintering. All these techniques rely on the externally applied pressure and sometimes as in the case for Hydrothermal Reaction Sintering (HRS) or Hydrothermal Hot Pressing (HHP) specially designed apparatus are needed. Sintering without the application of high temperature necessitates an externally applied pressure to intensify the driving force for densification (Fig. 1). Another typical feature is the assistance of liquid phase (commonly water) with or without the application of mild heating. In Fig. 2(a and b) the number of publications and patents recorded from 1970 is given, highlighting the contemporary growing interest. This review aims to explore such existing literature on all currently published low temperature densification works along with their advantages and disadvantages.

Initial studies related with sintering at low temperatures were conducted by Roy et al. [51,52] on cement mortar. The authors sintered the green compacts both by hot pressing around $150{ }^{\circ} \mathrm{C}$ with pressures in between 172 and $344 \mathrm{MPa}$, and without heating under a pressure of $\sim 700 \mathrm{MPa}$. The formed components demonstrated to have high relative densities with very few observable porosities and compressive strength values reaching around $510 \mathrm{MPa}$. Concurrently, novel instruments for hydrothermal reaction sintering, hydrothermal hot pressing were developed and practiced by Japanese researchers for the production of oxide ceramics in between 70 and 80s [53]. In late 70s, pure metals, alloys and few ceramic compositions like $\mathrm{NaCl}, \mathrm{MgO}$, TiC, etc. were sintered at room temperature (RT) under high (e.g. $4 \mathrm{GPa}$ ) pressures $[54,55]$. 


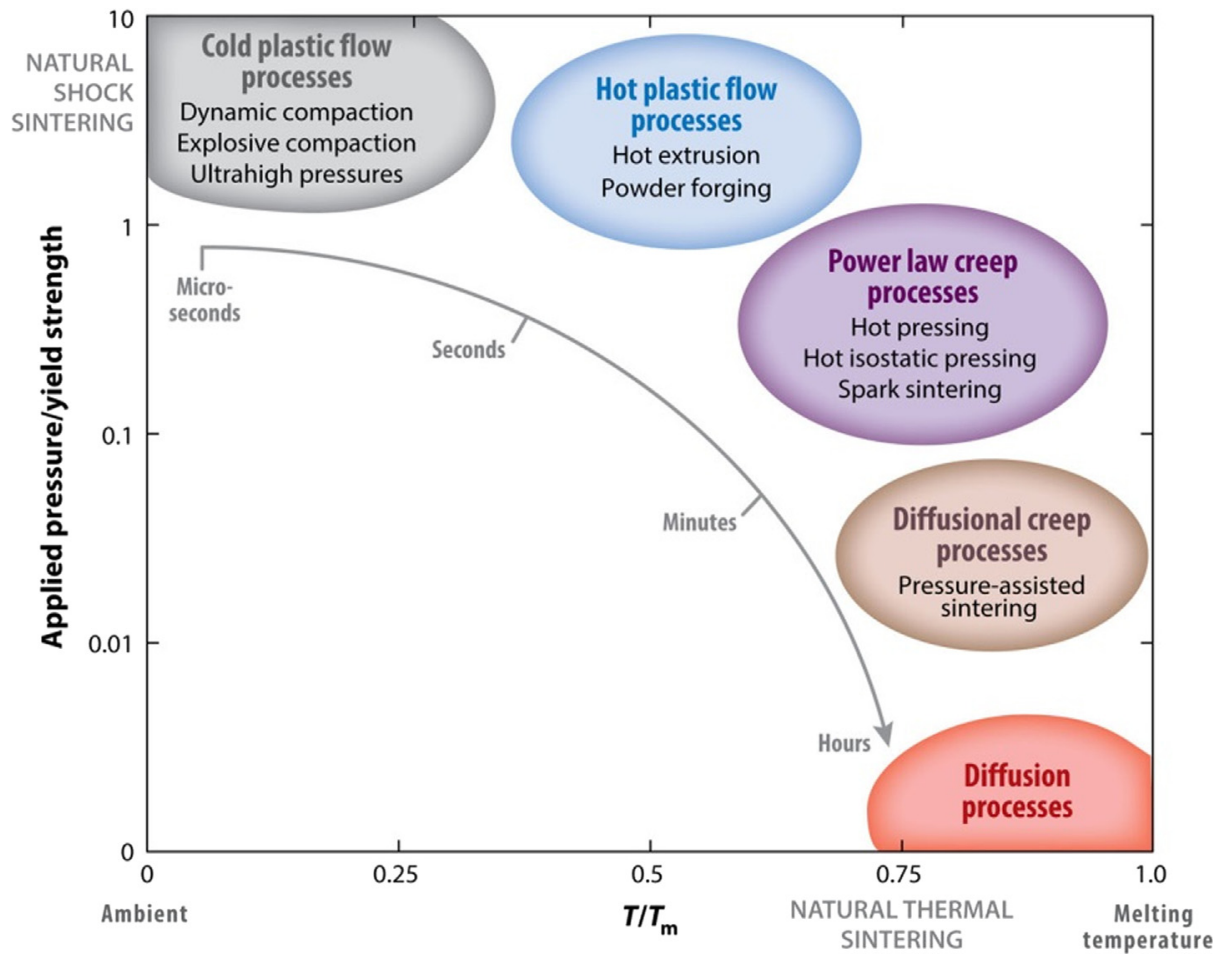

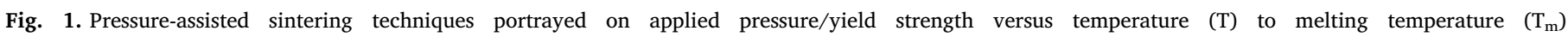

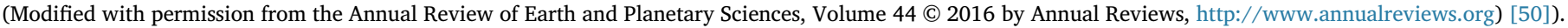

Following the pioneering works [56], in 2007 to study dissolutioncrystallization behavior akin to sedimentary rock formation, water constituting limestone $\left(\mathrm{CaCO}_{3}\right)$ green pellets were exposed to $\mathrm{CO}_{2}$ gas. The study conducted at RT, under altered $\mathrm{CO}_{2}$ pressure (up to $35 \mathrm{~atm}$ ) with different compaction pressures 10-15 MPa, and the term "cold sintering" (CS) was re-established [57]. In 2014, room-temperature densification (RTD) was demonstrated for $\mathrm{Li}_{2} \mathrm{MoO}_{4}$ and its composites [58]. Following RTD, another low-temperature densification technique called warm press (WP) was practiced [59]. Then finally, two techniques having different densification mechanisms referred as to cold sintering (CS) [60], and reactive hydrothermal liquid-phase densification (rHLPD) appeared concurrently [61]. The details for all of these methods and the

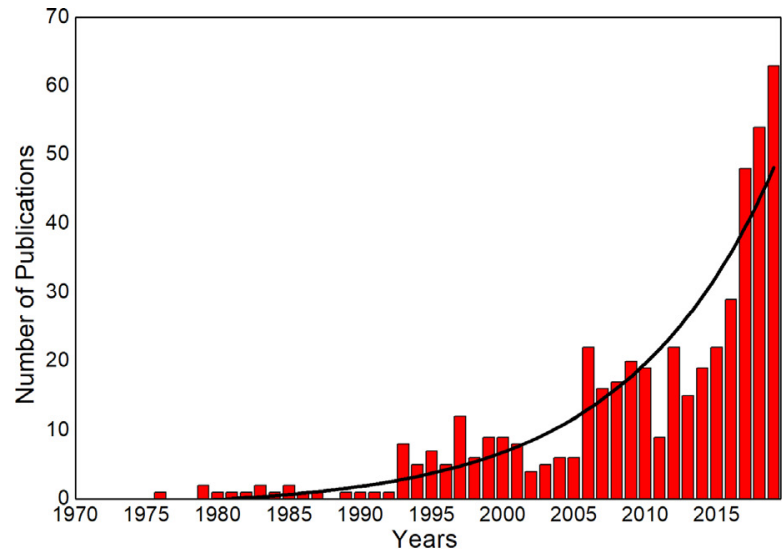

properties of the formed materials will be described in the subsequent sections.

\subsection{Hydrothermal reaction sintering}

Hydrothermal reaction sintering (HRS) is one of the most efficient methods used to obtain very high relative density (e.g. > 99\%) ceramic materials. As given in Eq. (I), reaction between highly pure metal (Me) powder or chips and water at a specific temperature $\left(500-1000{ }^{\circ} \mathrm{C}\right)$ and pressure $(100 \mathrm{MPa})$ levels results in the formation of sintered metal oxide (MeO) and hydrogen $\left(\mathrm{H}_{2}\right)$ gas [53]. The resultant $\mathrm{H}_{2}$ gas while leaving the system, induces the reaction to proceed further

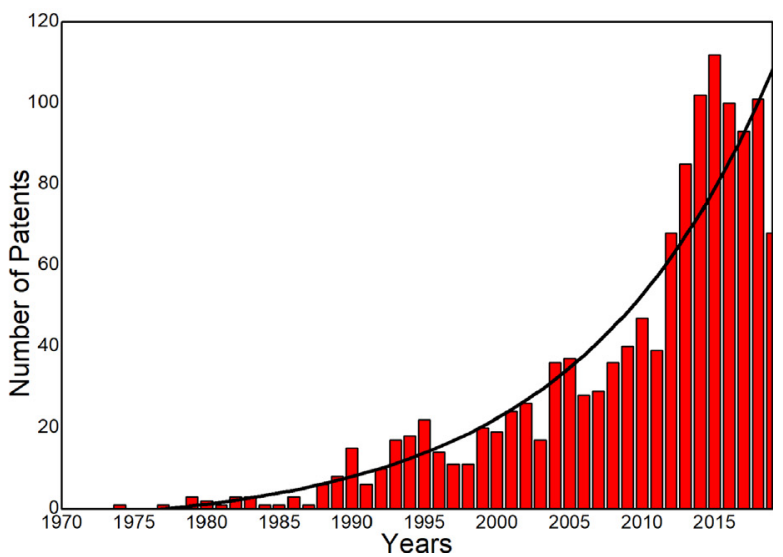

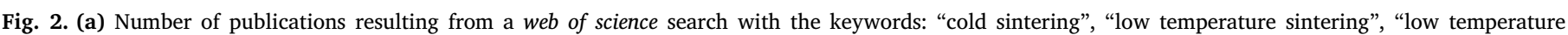

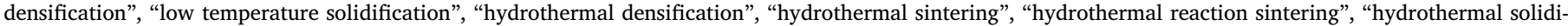

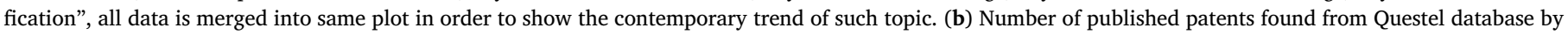

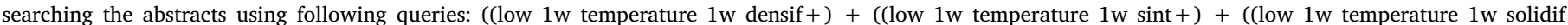

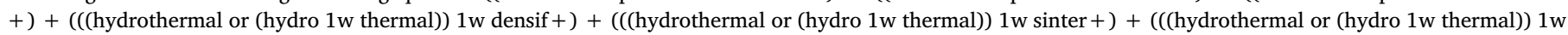

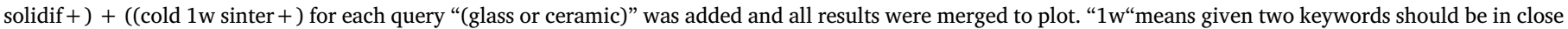
proximity. Both data was extracted from 1970, and the line represents an exponential growth function fit. 
(a)

$2 \mathrm{Cr}+3 \mathrm{H}_{2} \mathrm{O} \rightarrow \mathrm{Cr}_{2} \mathrm{O}_{3}+3 \mathrm{H}_{2}$

(b)

Test tube type
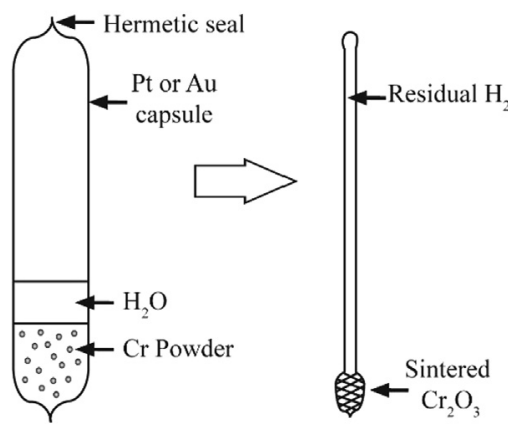

Final Stage

Initial Stage

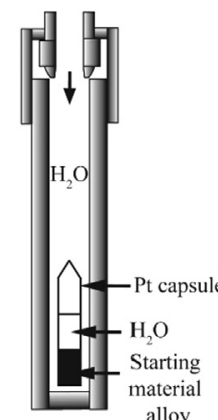

Closed system

Fig. 3. (a) HRS stages of $\mathrm{Cr}_{2} \mathrm{O}_{3}$, (b) apparatus used for hydrothermal reaction sintering [53] (Reprinted by permission from Springer: Hydrothermal Reactions for Materials Science and Engineering by S. Sōmiya Copyright 1989).

and more efficient compression for the component [62]. Although the temperatures specified in the process sounds like high, it is important to note that the formed oxides are commonly sintered at considerably higher temperatures than those stated. For example, traditionally hafnium oxide $\left(\mathrm{HfO}_{2}\right)$ is sintered at temperatures around $1800{ }^{\circ} \mathrm{C}$, instead similar relative densities can be achieved by HRS at temperatures in between 900 and $1000{ }^{\circ} \mathrm{C}$. HRS, therefore, is a relatively mild temperature sintering method [63], and is characterized by three distinct stages: (i) hydrothermal (by supercritical water) oxidation of the metal, (ii) diffusion of the $\mathrm{H}_{2}$ gas from the capsule, and (iii) sintering of the oxide powder consolidate [64].

$\mathrm{Me}+\mathrm{H}_{2} \mathrm{O} \rightarrow \mathrm{MeO}+\mathrm{H}_{2}$

The innovative work of Hirano and Somiya [62] showed how to obtain pure chromium oxide $\left(\mathrm{Cr}_{2} \mathrm{O}_{3}\right)$ tablets by using chromium $(\mathrm{Cr})$ powder (see Fig. 3(a)). The authors also formed stoichiometric magnetite single crystal without any other secondary phase formation [65]. During the monolithic $\mathrm{Cr}_{2} \mathrm{O}_{3}$ production; chromium powder and water were mixed and placed into the platinum capsule. The air was sealed with electric arc, and the capsule was placed in a test tube type pressure vessel (Fig. 3(b)). A pressure of $98 \mathrm{MPa}$ was applied at $1000{ }^{\circ} \mathrm{C}$, and it

was observed that $99.2 \%$ relative density was reached after $3 \mathrm{~h}$. For comparison, conventional sintering of $\mathrm{Cr}_{2} \mathrm{O}_{3}$ with $\mathrm{MgO}$ sintering aid (up to $0.1 \%$ by mass) at $1600{ }^{\circ} \mathrm{C} / 1 \mathrm{~h}$ resulted in the formation of magnesium chromite-spinel phase at the grain boundaries which prevented the grain growth, and densities of over 99\% were obtained [66].

$\mathrm{HfO}_{2}$ production was achieved with hafnium (Hf) metal chips at a temperature range of $800-1200{ }^{\circ} \mathrm{C}$ under $100 \mathrm{MPa}$ for $3 \mathrm{~h}$ process. No sintering was observed at $800{ }^{\circ} \mathrm{C}$ whereas components with relative densities of $92 \%$ and $98 \%$ were obtained at $900{ }^{\circ} \mathrm{C}$ and $1000{ }^{\circ} \mathrm{C}$, respectively. X-ray density of $\mathrm{HfO}_{2}$ was only reached by $1200{ }^{\circ} \mathrm{C}$ treatment [64]. The formation of monolithic $\mathrm{ZrO}_{2}$ ceramics with no flaws is difficult to obtain by traditional sintering due to crack formation during monoclinic-tetragonal phase transition, besides temperatures above $1600{ }^{\circ} \mathrm{C}$ are required. HRS was used as a remedy to sinter $\mathrm{ZrO}_{2}$ at temperatures below the phase transition causing no cracking. Samples with a relative density of $99 \%$ were formed by HRS as a result of the reaction between metallic $\mathrm{Zr}$ and supercritical water at $1000{ }^{\circ} \mathrm{C} / 3 \mathrm{~h}$ under $98 \mathrm{MPa}$ pressure $\cdot \mathrm{H}_{2} \mathrm{O} / \mathrm{Zr}$ initial ratio was found to be critical for densification and above certain level no well sintered bodies were obtained [67-69]. Apart from the ceramic compositions given above, the technique was also conducted to obtain others such as iron oxides ( $\mathrm{FeO}$, $\left.\mathrm{Fe}_{3} \mathrm{O}_{4}\right)$ and lanthanum chromite $\left(\mathrm{LaCrO}_{3}\right)$ [53].

\subsection{Hydrothermal hot pressing}

Hydrothermal hot pressing (HHP) is used to sinter inorganic powders under hydrothermal conditions but at much lower temperatures $\left(<500{ }^{\circ} \mathrm{C}\right)$ compared to HRS $[70,71]$. HHP was described as a process of artificial lithification [72], since the processing temperatures are as low as seen in geology, it can also be called as a geo-mimetic process.

There are two basic prerequisites for HHP to proceed successfully: compaction of the sample under hydrothermal conditions, and a path (space) for water removal. Compression accelerates the packing of the initial powder, meanwhile avoiding the development of shrinkage cracks. Compaction is dependent on the speed at which water is removed from the starting powder mixture. If there is no path for the water retreat, it remains in the pores and prevents densification [70]. The final relative density in the HHP depends on processing temperature, pressure, time and amount of water used [70]. Fig. 4(a) provides the schematic drawing of the HHP equipment, while Fig. 4(b) shows the

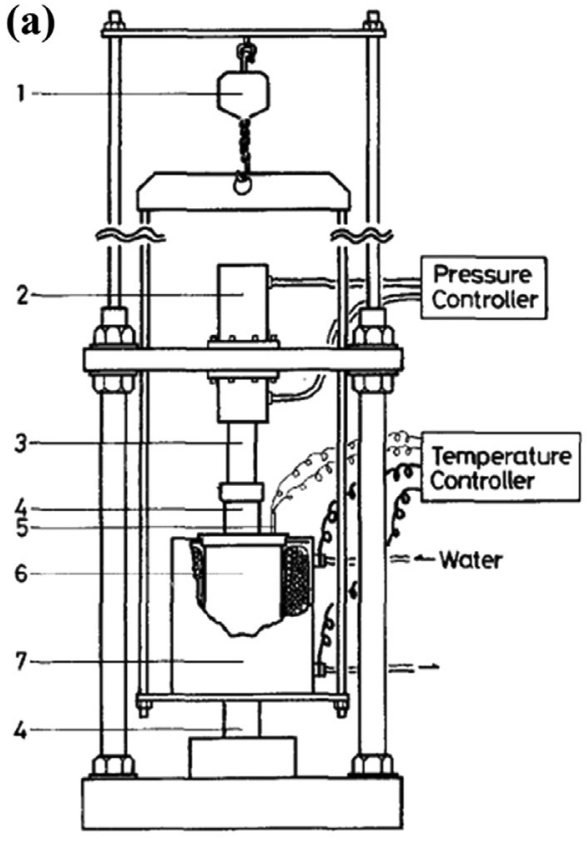

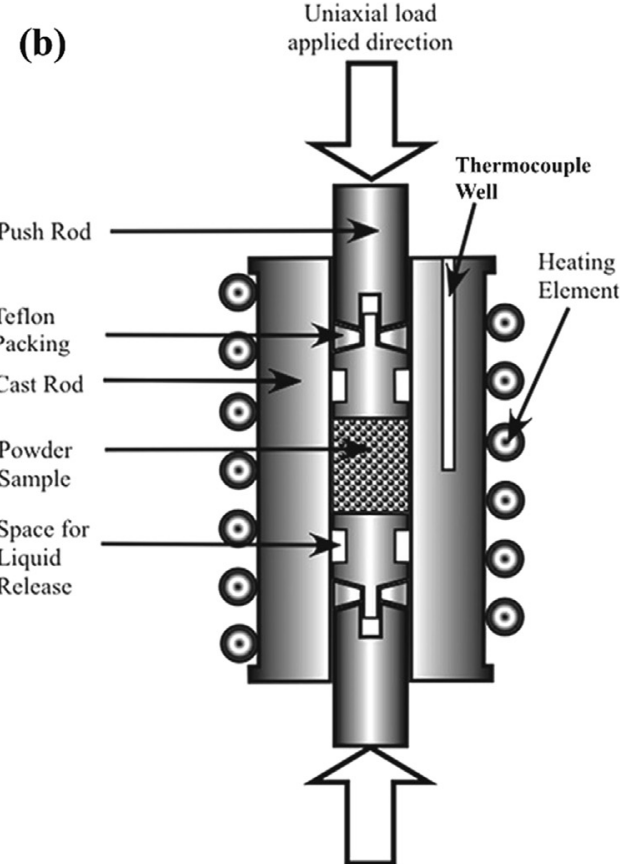

Fig. 4. (a) HHP equipment details 1: crane for adjusting the furnace position, 2: pump, 3: ram, 4: autoclave push rod, 5: thermocouple, 6: autoclave, 7: induction furnace [53,72], (b) hydrothermal hot pressing autoclave (Reprinted by permission from Springer: Hydrothermal Reactions for Materials Science and Engineering by S. Sōmiya Copyright 1989) (Reprinted from [73], Copyright (2015), with permission from Elsevier). 
autoclave details $[53,73]$.

One of the first applications of HHP was conducted on a mixture of $\alpha$-quartz and amorphous silica. After addition of $\mathrm{NaOH}$ including aqueous solutions, the blend was pressed under $180 \mathrm{MPa}$ pressure. The sample then placed in autoclave which was heated in between 120 and $350{ }^{\circ} \mathrm{C}$ under $27 \mathrm{MPa}$ pressure for $30 \mathrm{~min}$ [72]. In other studies; $\mathrm{CaCO}_{3}$ [74], and subsequently $\mathrm{TiO}_{2}$ was formed. In the process; $\mathrm{TiO}_{2}(800 \mathrm{~nm}$ average particle size) was mixed with water, placed in autoclave, compressed by the push rod to $200 \mathrm{MPa}$ pressure while heated to $350{ }^{\circ} \mathrm{C}$ for $30 \mathrm{~min}$. The relative density of sintered $\mathrm{TiO}_{2}$ pellet was found to be $71 \%[75]$.

In a more recent work, silica ( $50 \mathrm{~nm}$ in size) synthesized by Stöber process was mixed with $\mathrm{NaOH}$ aqueous solutions to improve silica dissolution-precipitation process. Initially the blend was pressed by $190 \mathrm{MPa}$, followed by cold isostatic pressing at $500 \mathrm{MPa} / 5 \mathrm{~min}$. The relative densities of the green bodies were in between 50 and $55 \%$. These tablets were subjected to "hydrothermal sintering" using a modified HHP equipment operated at RT with $127 \mathrm{MPa}$ pressure, then at $150{ }^{\circ} \mathrm{C}$, and finally at $300{ }^{\circ} \mathrm{C}$ under $350 \mathrm{MPa}$ pressure for $90 \mathrm{~min}$. Monolithic amorphous silica samples having $86 \%$ relative density was obtained by using the lowest $\mathrm{NaOH}$ concentration while $\alpha$-quartz having $98 \%$ relative density was reached when concentrated $\mathrm{NaOH}$ solution was used [76]. The same research group studied also the effect of water. Three different types of silica: naturally hydrated, partially dehydrated, and deliberately added water powders were all subjected to HHP procedure. After the formation of green bodies, densification was followed under $95 \mathrm{MPa}$ pressure at RT, followed by the application of $190 \mathrm{MPa}$ pressure at $300{ }^{\circ} \mathrm{C}$ for $90 \mathrm{~min}$. The relative densities of natural hydrated, partially hydrated, and added water were found to be around $67 \%, 63-67 \%$, and $75 \%$, respectively. The study suggested that the addition of water enhances the densification [77]. Apart from those few detailed ones, there are numerous compositions obtained by using HHP as given in Table 1.

After the application of HHP, a new technique called double layered capsule hydrothermal hot-pressing (DC-HHP) was developed particularly to prepare coatings like hydroxyapatite on metals. In this method, a cylindrical capsule that has double layer structure is used and subjected to isostatic pressing, see Fig. 5 for device schematics. Between inner and outer capsule, alumina powder is placed to maintain the space for water retreat. Hydroxyapatite-coated magnesium [129], and titanium $[133,134,189]$, were produced by using DC-HHP.

\subsection{Room-temperature densification}

It should be noted here that the terminology describing below is currently not standardized and can be confusing; consequently, we merged all the studies conducted at RT to densify ceramic and glass artifacts in room-temperature densification (RTD) section.

In late $90 \mathrm{~s}$, a research group from Brazil worked on compaction of nanosized ceramics powders under very high pressures (4.5-5 GPa) at RT. Both $\gamma-\mathrm{Al}_{2} \mathrm{O}_{3}$ powder (in water) and silica-gel ( $15 \mathrm{~nm}$ particle size) were consolidated at nearly hydrostatic conditions which yielded in the formation of transparent $\mathrm{SiO}_{2}$ samples having 86\%, and translucent alumina components having $92 \%$ relative density. It was one of the first studies that obtained densified $\gamma-\mathrm{Al}_{2} \mathrm{O}_{3}$, and the measured Vickers microhardness $(50 \mathrm{~g})$ values were around 4.0 GPa for the silica, and 5.7 $\mathrm{GPa}$ for the $\gamma-\mathrm{Al}_{2} \mathrm{O}_{3}$. For silica components, the densification was related with the bridging silanol groups promoting the dehydration (up to $60 \%$ ), and the consolidation mechanism was named as "cold sintering" [190-192]. During the last decade, the published studies using cold sintering terminology (see later) have become the object of steadily growing interest. However, the "cold sintering" term in those contemporary works defines a variant process (with much milder pressure and higher temperature conditions) from the ones given obtained by RT processes.

In 2014, researchers from Oulu University demonstrated the possibility to produce monolithic lithium molybdate $\left(\mathrm{Li}_{2} \mathrm{MoO}_{4}\right)$ ceramics at RT. The authors called the method as room-temperature densification (RTD) which was simply based on the compression (under $130 \mathrm{MPa}$ pressure) of the $\mathrm{Li}_{2} \mathrm{MoO}_{4}$ powder (sieved below $180 \mu \mathrm{m}$ ) together with small amount of water. The pellets were then processed in different ways: (i) conventionally sintered at $540{ }^{\circ} \mathrm{C}$ (control sample), (ii) application of RTD and dried at $120^{\circ} \mathrm{C}$, and (iii) application of RTD and dried at RT. While the densification mechanisms were not discussed in detail, it was shown that $\mathrm{Li}_{2} \mathrm{MoO}_{4}$ solubility in water caused the formation of dense components even at RT. In Fig. 6(a and b) SEM images taken from $\mathrm{Li}_{2} \mathrm{MoO}_{4}$ tablets produced by both conventional sintering and RTD are given, and as seen the microstructures resemble each other $[58,193]$. The same group studied the formation of $\mathrm{Li}_{2} \mathrm{MoO}_{4}$ - MnZn ferrite [194] and $\mathrm{Li}_{2} \mathrm{MoO}_{4}-\mathrm{TiO}_{2}$ [195] ceramic composites, besides processing, applications such as ultra-wideband (UWB) or circular polarized GPS antennas were explored [196,197].

Recently, Bouville and Studart [35] synthesized nanosized $\mathrm{CaCO}_{3}$; vaterite with average size of $37 \mathrm{~nm}$ and agglomerated as $600 \mathrm{~nm}$ forms. The synthesized nano-vaterite together with water was subjected to sintering under pressures up to $800 \mathrm{MPa}$ at RT. Relative density of $87 \%$ was obtained by $500 \mathrm{MPa}$ pressure at RT, and the samples demonstrated $30 \mathrm{GPa}$ elastic modulus, $50 \mathrm{MPa}$ flexural, and $225 \mathrm{MPa}$ compressive strength. It has been shown that RT densified nano-vaterite component exhibited higher mechanical properties than that of several state-of-the-art construction materials such as stone or concrete. In a recent variant work by Jiang et al., used an isostatic pressure to densify the silica components instead of the uniaxial pressure at RT, and named the process as cold hydrostatic sintering [198]. In Table 2 ceramic compositions currently produced by RTD, processing conditions and the obtained properties are given.

\subsection{Cold sintering}

Cold sintering (CS) allows densification under mid/high pressures (below $1 \mathrm{GPa}$ ) and low temperatures $\left(<350{ }^{\circ} \mathrm{C}\right)$ with the aid of a deliberately added temporary fluid (solvent/liquid) [203,204]. In the process, the initial raw material mixture is continuously compressed by using a simple uniaxial press. Heating is carried out by a resistance jacket wrapped around the mold/die system, see Fig. 7(a-c) for the CS equipment used [205].

The CS process, as defined by Maria et al. [201], consists of two stages in which different densification mechanisms probably proceeding, see Fig. 8. First, compaction is applied to a mixture of ceramic powder (generally nano-sized since high surface-to-volume ratio delivers a strong driving force) with liquid (mostly water) under a uniaxial force similar to that of conventional pressing. In this step the liquid phase serves as a lubrication medium increasing the particle sliding, while discharging continuously from the die tolerance. Besides, probably the applied pressure increases the solubility of the particles having sharp edges, and overall causing a better compaction compared to that of dry consolidation. Such issue has already been documented by Shotton and Rees to consolidate $\mathrm{NaCl}$ at $\mathrm{RT}$ under varying humidity conditions [206].

Second, the system is heated to higher temperatures while compressing under moderate pressure levels (e.g. $500 \mathrm{MPa}$ ). The solubility of the powder is further increased and together with the evaporation of a liquid phase, the formation of supersaturated liquid is ensured. At this stage the applied pressure, as in the case for pressure-assisted conventional sintering, promotes densification. It is proposed that the latter stage is dominated by dissolution-precipitation events assisted by pressure and temperature [201].

It should be noted that the formation of a supersaturated liquid is essential for densification and it can also be accomplished by dissolving the starting particles in acidic or basic solutions or just by preloading the liquid phase with the corresponding chemical groups, i.e. the addition of a water-soluble salts instead of modifying the acidity. 
Table 1

List of materials produced by hydrothermal hot pressing, together with processing conditions and some of the observed properties.

\begin{tabular}{|c|c|c|c|c|}
\hline Materials & Processing conditions & Properties & Relative density (\%) & Ref. \\
\hline $\mathrm{Al}_{2} \mathrm{O}_{3}$ & $\begin{array}{l}110{ }^{\circ} \mathrm{C} \\
40 \mathrm{MPa} \\
2 \mathrm{~h}\end{array}$ & $\mathrm{SSA}=450 \mathrm{~m}^{2} / \mathrm{g}$ & $\sim 33^{*}$ & {$[78]$} \\
\hline $\mathrm{AlPO}_{4}$ & $\begin{array}{l}150{ }^{\circ} \mathrm{C} \\
40 \mathrm{MPa} \\
2 \mathrm{~h}\end{array}$ & $\mathrm{SSA}=40-107 \mathrm{~m}^{2} / \mathrm{g}$ & $\sim 35-54^{*}$ & {$[79]$} \\
\hline $\mathrm{Ca}_{5}\left(\mathrm{PO}_{4}\right)_{3}(\mathrm{OH})-\left(\mathrm{Ti}_{0.40} \mathrm{Zr}_{0.10} \mathrm{Cu}_{0.36} \mathrm{Pd}_{0.14}\right)_{99} \mathrm{Ca}_{1}$ & $\begin{array}{l}150{ }^{\circ} \mathrm{C} \\
40 \mathrm{MPa} \\
2 \mathrm{~h}\end{array}$ & N.A. & N.A. & {$[80,81]$} \\
\hline $\mathrm{AlO}(\mathrm{OH})$ & $\begin{array}{l}180{ }^{\circ} \mathrm{C} \\
80 \mathrm{MPa} \\
3 \mathrm{~h}\end{array}$ & N.A. & N.A. & {$[82]$} \\
\hline Calcium aluminate/phosphate cement & $\begin{array}{l}300{ }^{\circ} \mathrm{C} \\
40 \mathrm{MPa} \\
1 \mathrm{~h}\end{array}$ & $\sigma \sim 5-31 \mathrm{MPa}$ & N.A. & [83] \\
\hline $\mathrm{Ca}_{3} \mathrm{Co}_{4} \mathrm{O}_{9}$ & $\begin{array}{l}100-300{ }^{\circ} \mathrm{C} \\
50-200 \mathrm{MPa} \\
1-5 \mathrm{~h}\end{array}$ & $\begin{array}{l}\rho \sim 90-210 \mu \Omega . \mathrm{m} \\
k \sim 1.1-1.5 \mathrm{~W} / \mathrm{m} . \mathrm{K}\end{array}$ & $75-90$ & {$[84,85]$} \\
\hline $\mathrm{CaCO}_{3}$ & $\begin{array}{l}50-300{ }^{\circ} \mathrm{C} \\
5-68 \mathrm{MPa} \\
0.17-10 \mathrm{~h}\end{array}$ & $\begin{array}{l}\sigma_{\mathrm{c}} \sim 5-160 \mathrm{MPa} \\
\sigma \sim 2-8 \mathrm{MPa} \\
\mathrm{H}_{\mathrm{v}}=0.3-10 \mathrm{GPa}\end{array}$ & $\sim 56-92^{*}$ & {$[56,74,86-89]$} \\
\hline $\mathrm{CaCO}_{3}-\mathrm{MgCO}_{3}$ & $\begin{array}{l}300{ }^{\circ} \mathrm{C} \\
25 \mathrm{MPa} \\
10 \mathrm{~min}\end{array}$ & $\sigma_{\mathrm{c}}=37.1-44.3 \mathrm{MPa}$ & N.A. & {$[90]$} \\
\hline $\mathrm{CaCO}_{3}-\mathrm{SrCO}_{3}$ & $\begin{array}{l}200-300{ }^{\circ} \mathrm{C} \\
25 \mathrm{MPa}\end{array}$ & N.A. & $\sim 85^{*}$ & [91] \\
\hline $\mathrm{Ca}_{2} \mathrm{O}_{4} \mathrm{Si}$ & $\begin{array}{l}200{ }^{\circ} \mathrm{C} \\
10-20 \mathrm{MPa} \\
17-30 \mathrm{~min}\end{array}$ & $\begin{array}{l}\sigma \sim 3-10 \mathrm{MPa} \\
\sigma_{\mathrm{bs}}=11 \mathrm{MPa}\end{array}$ & $\sim 43-69^{*}$ & {$[92,93]$} \\
\hline $\mathrm{Ce}\left(\mathrm{PO}_{3}\right)_{4}$ & $\begin{array}{l}150-200{ }^{\circ} \mathrm{C} \\
40-80 \mathrm{MPa} \\
2 \mathrm{~h}\end{array}$ & N.A. & $\sim 72-84$ & {$[94,95]$} \\
\hline $\mathrm{Cu}_{3}\left(\mathrm{PO}_{4}\right)_{2} \& \mathrm{Cu}_{2} \mathrm{P}_{4} \mathrm{O}_{12}$ & $\begin{array}{l}150{ }^{\circ} \mathrm{C} \\
40 \mathrm{MPa} \\
2 \mathrm{~h}\end{array}$ & $\mathrm{SSA}=0.5-3 \mathrm{~m}^{2} / \mathrm{g}$ & $\sim 53-82$ & {$[96]$} \\
\hline Geopolymers & $\begin{array}{l}200{ }^{\circ} \mathrm{C} \\
8.5 \mathrm{MPa} \\
45 \mathrm{~min}\end{array}$ & $\sigma_{\mathrm{c}} \sim 55.3-103.3 \mathrm{MPa}$ & N.A. & {$[97]$} \\
\hline Glasses & $\begin{array}{l}100-350{ }^{\circ} \mathrm{C} \\
15-60 \mathrm{MPa} \\
5 \mathrm{~min}-8 \mathrm{~h}\end{array}$ & $\begin{array}{l}\mathrm{H}_{\mathrm{v}}=1-3 \mathrm{GPa} \\
\sigma_{\mathrm{c}}=150-460 \mathrm{MPa} \\
\sigma \sim 4-65 \mathrm{MPa} \\
k \sim 0.1-0.2 \mathrm{~W} / \mathrm{m} . \mathrm{K}\end{array}$ & N.A. & {$[73,98-110]$} \\
\hline $\mathrm{Ca}_{10}\left(\mathrm{PO}_{4}\right)_{6}(\mathrm{OH})_{2}$ & $\begin{array}{l}100-300{ }^{\circ} \mathrm{C} \\
10-150 \mathrm{MPa} \\
0-48 \mathrm{~h}\end{array}$ & $\begin{array}{l}\mathrm{H}_{\mathrm{v}}=0.4-2.9 \mathrm{GPa} \\
\sigma \sim 1-22 \mathrm{MPa} \\
\sigma_{\mathrm{c}}=\sim 15-150 \mathrm{MPa}\end{array}$ & $\sim 30-98$ & [111-124] \\
\hline $\mathrm{Ca}_{10}\left(\mathrm{PO}_{4}\right)_{6}(\mathrm{OH})_{2}$-Chitosan & $\begin{array}{l}150{ }^{\circ} \mathrm{C} \\
40 \mathrm{MPa} \\
2 \mathrm{~h}\end{array}$ & $\sigma \sim 12-20 \mathrm{MPa}$ & $\sim 50$ & {$[114,125]$} \\
\hline $\mathrm{Ca}_{10}\left(\mathrm{PO}_{4}\right)_{6}(\mathrm{OH})_{2}$-Glass & $\begin{array}{l}325^{\circ} \mathrm{C} \\
47 \mathrm{MPa} \\
30 \mathrm{~min}\end{array}$ & $\sigma_{\mathrm{c}}=206 \mathrm{MPa}$ & 65 & [126] \\
\hline $\mathrm{Ca}_{10}\left(\mathrm{PO}_{4}\right)_{6}(\mathrm{OH})_{2}-\mathrm{Ca}_{3}\left(\mathrm{PO}_{4}\right)_{2}$ & $\begin{array}{l}250{ }^{\circ} \mathrm{C} \\
150 \mathrm{MPa} \\
1-3 \mathrm{~h}\end{array}$ & $\sigma_{\mathrm{c}}=2.5 \mathrm{MPa}$ & $30-40$ & {$[127,128]$} \\
\hline $\mathrm{Ca}_{10}\left(\mathrm{PO}_{4}\right)_{6}(\mathrm{OH})_{2}-\mathrm{AZ31} ; \mathrm{Mg}-3 \mathrm{Al}-\mathrm{IZn}$ & $\begin{array}{l}150{ }^{\circ} \mathrm{C} \\
40 \mathrm{MPa} \\
2-3 \mathrm{~h}\end{array}$ & N.A. & N.A. & {$[129,130]$} \\
\hline $\mathrm{Ca}_{10}\left(\mathrm{PO}_{4}\right)_{6}(\mathrm{OH})_{2}-\mathrm{Ti}$ alloy & $\begin{array}{l}50-150{ }^{\circ} \mathrm{C} \\
20-80 \mathrm{MPa} \\
2-24 \mathrm{~h}\end{array}$ & N.A. & N.A. & [131-137] \\
\hline $\mathrm{Ca}_{10}\left(\mathrm{PO}_{4}\right)_{6}(\mathrm{OH})_{2}-\mathrm{Ti}_{40} \mathrm{Zr}_{10} \mathrm{Cu}_{36} \mathrm{Pd}_{14}$ & $\begin{array}{l}150{ }^{\circ} \mathrm{C} \\
40 \mathrm{MPa} \\
2 \mathrm{~h}\end{array}$ & N.A. & N.A. & {$[138,139]$} \\
\hline $\mathrm{La}\left(\mathrm{PO}_{3}\right)_{3}$ & $\begin{array}{l}50-150{ }^{\circ} \mathrm{C} \\
5-30 \mathrm{MPa} \\
1 \mathrm{~h}\end{array}$ & N.A. & N.A. & {$[140,141]$} \\
\hline $\mathrm{La}_{1-\mathrm{x}} \mathrm{Sr}_{\mathrm{x}} \mathrm{MnO}_{3}-\mathrm{SiO}_{2}$ & $\begin{array}{l}300{ }^{\circ} \mathrm{C} \\
350 \mathrm{MPa} \\
90 \mathrm{~min}\end{array}$ & $\rho=960-7.8 \times 10^{7} \Omega . \mathrm{cm}$ & $\sim 80$ & {$[142,143]$} \\
\hline $\mathrm{Na}_{\mathrm{x}} \mathrm{Co}_{2} \mathrm{O}_{4}$ & $\begin{array}{l}200-250{ }^{\circ} \mathrm{C} \\
100-200 \mathrm{MPa} \\
1 \mathrm{~h}\end{array}$ & $\rho=20-45 \mu \Omega . m$ & $\sim 94-99$ & [144] \\
\hline
\end{tabular}


Table 1 (continued)

\begin{tabular}{|c|c|c|c|c|}
\hline Materials & Processing conditions & Properties & Relative density (\%) & Ref. \\
\hline $\mathrm{Ca}_{8}\left(\mathrm{HPO}_{4}\right)_{2}\left(\mathrm{PO}_{4}\right)_{4} 5 \mathrm{H}_{2} \mathrm{O}$ & $\begin{array}{l}110{ }^{\circ} \mathrm{C} \\
40 \mathrm{MPa} \\
2 \mathrm{~h}\end{array}$ & $\sigma_{\mathrm{c}}=33 \mathrm{MPa}$ & N.A. & [145] \\
\hline Phosphate bonded $\mathrm{Al}_{2} \mathrm{O}_{3}$ & $\begin{array}{l}250{ }^{\circ} \mathrm{C} \\
40 \mathrm{MPa} \\
1 \mathrm{~h}\end{array}$ & $\sigma=3-24 \mathrm{MPa}$ & N.A. & {$[146]$} \\
\hline $\mathrm{SiO}_{2}$ & $\begin{array}{l}100-350{ }^{\circ} \mathrm{C} \\
10-350 \mathrm{MPa} \\
\leq 12 \mathrm{~h}\end{array}$ & $\begin{array}{l}\mathrm{SSA}=467-1339 \mathrm{~m}^{2} / \mathrm{g} \\
\sigma_{\mathrm{c}}=5-230 \mathrm{MPa} \\
\mathrm{H}_{\mathrm{v}} \sim 0.7-2.1 \mathrm{GPa}\end{array}$ & $\sim 23-98^{*}$ & {$[70,76,77,147-157]$} \\
\hline $\mathrm{SrCO}_{3}$ & $\begin{array}{l}200-300{ }^{\circ} \mathrm{C} \\
25 \mathrm{MPa}\end{array}$ & $\sigma_{\mathrm{c}} \sim 80-190 \mathrm{MPa}$ & $\sim 93$ & [91] \\
\hline $\mathrm{Sn}_{1.24} \mathrm{Ti}_{1.94} \mathrm{O}_{3.66}(\mathrm{OH})_{1.50} \mathrm{~F}_{1.42}$ & $\begin{array}{l}210-300{ }^{\circ} \mathrm{C} \\
60-120 \mathrm{MPa} \\
0-4 \mathrm{~h}\end{array}$ & N.A. & $\sim 86-99$ & [158] \\
\hline $\mathrm{TiO}_{2}$ & $\begin{array}{l}100-350{ }^{\circ} \mathrm{C} \\
15-200 \mathrm{MPa} \\
0.17-5 \mathrm{~h}\end{array}$ & $\begin{array}{l}\mathrm{SSA}=50-300 \mathrm{~m}^{2} / \mathrm{g} \\
\mathrm{H}_{\mathrm{v}}=0.2-7.8 \mathrm{GPa} \\
\sigma_{\mathrm{c}}=5-60 \mathrm{MPa}\end{array}$ & $\sim 42-98^{*}$ & {$[70,75,159-164]$} \\
\hline $\mathrm{Ca}_{6} \mathrm{Si}_{6} \mathrm{O}_{17}(\mathrm{OH})_{2}$-Chitosan & $\begin{array}{l}150{ }^{\circ} \mathrm{C} \\
20 \mathrm{MPa} \\
10-30 \mathrm{~min}\end{array}$ & $\sigma \sim 5-12 \mathrm{MPa}$ & N.A. & {$[165]$} \\
\hline Y-Zeolite & $\begin{array}{l}110-200{ }^{\circ} \mathrm{C} \\
40 \mathrm{MPa} \\
<12 \mathrm{~h}\end{array}$ & $\begin{array}{l}\mathrm{SSA}=540-890 \mathrm{~m}^{2} / \mathrm{g} \\
\mathrm{H}_{\mathrm{v}}=0.2-3 \mathrm{GPa}\end{array}$ & $\sim 57-99^{*}$ & [166-168] \\
\hline Zeolite-Al & $\begin{array}{l}130{ }^{\circ} \mathrm{C} \\
40 \mathrm{MPa} \\
1 \mathrm{~h}\end{array}$ & N.A. & N.A. & [169] \\
\hline Zeolite-Kaolin clay & $\begin{array}{l}110-220{ }^{\circ} \mathrm{C} \\
40.53 \mathrm{MPa} \\
0.5 \mathrm{~h}\end{array}$ & $\begin{array}{l}\sigma_{\mathrm{c}}=10-24.7 \mathrm{MPa} \\
\mathrm{SSA}=70-118 \mathrm{~m}^{2} / \mathrm{g}\end{array}$ & N.A. & {$[170]$} \\
\hline $\mathrm{ZrO}_{2}$ & $\begin{array}{l}350{ }^{\circ} \mathrm{C} \\
70 \mathrm{MPa}\end{array}$ & N.A. & N.A. & {$[171]$} \\
\hline Materials to cure environmental problems & - & - & - & [172-188] \\
\hline
\end{tabular}

N.A.: Not available, SSA: Specific surface area, $\boldsymbol{\sigma}$ : Tensile strength, $\boldsymbol{\sigma}_{\mathbf{b s}}$ : Bending strength, $\boldsymbol{\sigma}_{\mathbf{c}}$ : Compressive strength, $k$ : Thermal conductivity, $\rho$ : Electrical resistivity, $\mathbf{H}_{\mathrm{v}}$ : Vickers hardness, *Calculated
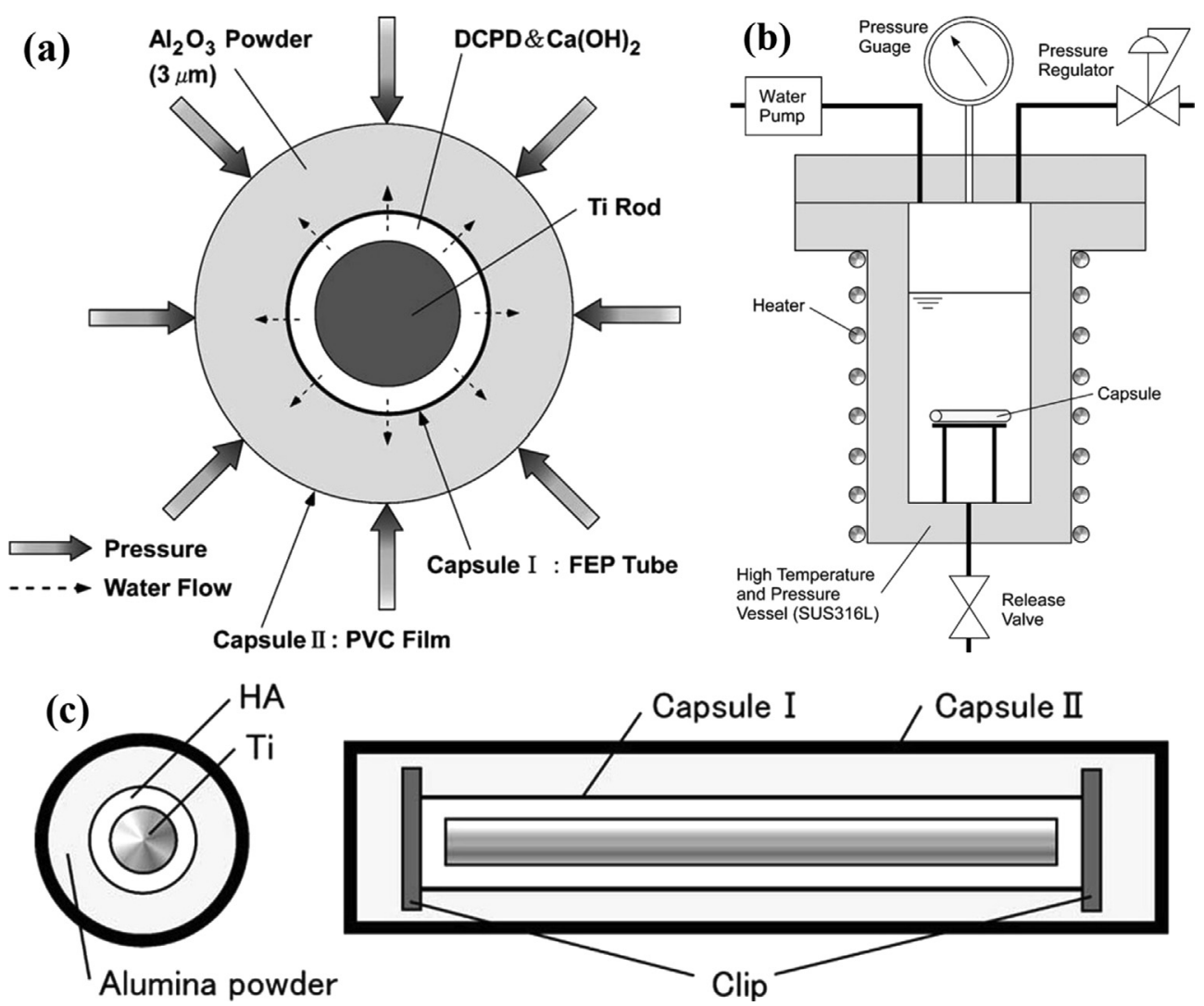

Fig. 5. Schematic representation of double layered capsule hydrothermal hot-pressing (DC-HHP) system: (a) top view of the DC-HHP, (b) cross-sectional view of the autoclave with reaction capsule, (c) cross-section of the capsule (Reprinted from [133], Copyright (2006), with permission from Elsevier). 

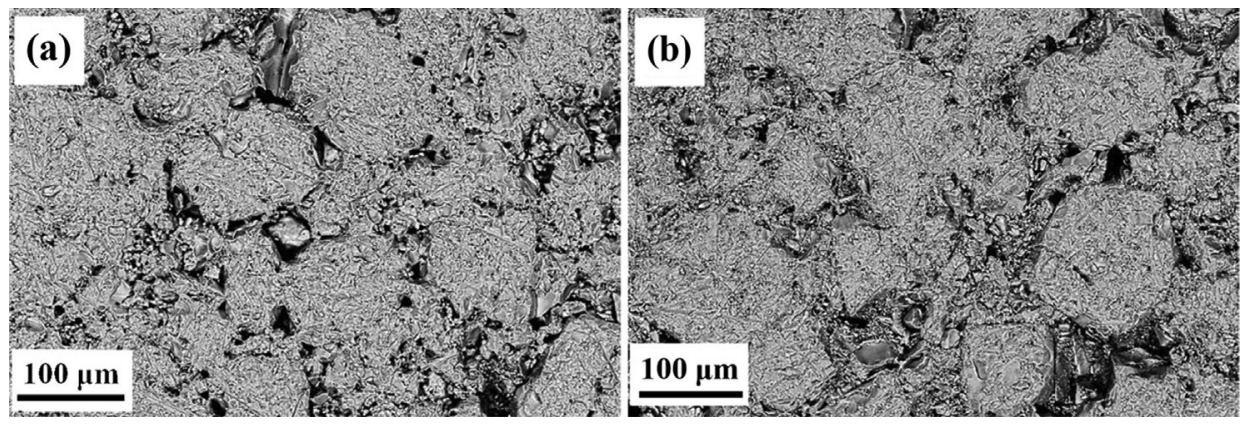

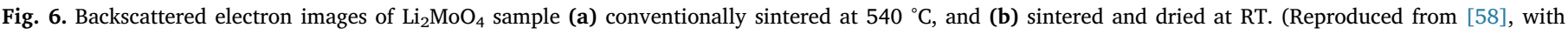
permission from John Wiley and Sons, Copyright 2014).

Accordingly, ZnO (basic nature) could be cold sintered to high levels (relative density over 90\%) simply by using a liquid consisting of acetic acid solution (in water) [205], a liquid/solution consisting of dissolved zinc salts such as zinc acetate or dimethyl sulfoxide [207], similar to the case for $\mathrm{Y}_{2} \mathrm{O}_{3}$ which has very low solubility [201].

Table 3 shows the list of the ceramic components produced by CS process together with the data extracted for properties. Although CS technique is broadly used nowadays, and wide variety of chemistries from the family of oxides, carbonates, phosphates, bromides, chlorides, and fluorides have already been produced, most of these published works in the scientific literature so far, have been primarily directed to the production of electro-ceramics. The details for the production of such components can be found elsewhere [60,203,208], and here only few essential compositions will be discussed.

At present, some compositions cannot be produced directly by CS such as carbides. Besides, some oxides such as $\mathrm{ZrO}_{2}$ with high relative density have not been achieved by CS although several attempts were conducted. An additional heat treatment process (around $1100^{\circ} \mathrm{C}$ ) was needed to obtain high relative densities $\sim 95 \%$. Despite that such that temperatures are still lower than the conventional sintering temperatures, suggesting the benefits of the process [209-212].

A recent study compared the electrical properties of the CS made $\mathrm{ZnO}$ ceramics with that of solid-state sintered ceramics (green pellet was formed under $180 \mathrm{MPa}$ by using $240 \mathrm{~nm}$ average particle size and sintering at $1400{ }^{\circ} \mathrm{C}$ in air). The results demonstrated that the samples produced by $\mathrm{CS}$ at $300{ }^{\circ} \mathrm{C}$ exhibited the same electrical conductivity characteristics as those produced by conventional sintering. Such data is important considering the production cost and greenness of CS for industrial applications (varistors, sensors, etc.) [205].

Different ferroelectric materials $\left(\mathrm{KH}_{2} \mathrm{PO}_{4}, \mathrm{~Pb}(\mathrm{Zr}, \mathrm{Ti}) \mathrm{O}_{3}, \mathrm{NaNO}_{2}\right.$, $\mathrm{SrTiO}_{3}$ and $\mathrm{BaTiO}_{3}$ ) were produced at temperatures below $300{ }^{\circ} \mathrm{C}$
$[60,213-215]$. For the production of $\mathrm{BaTiO}_{3}$, the $\mathrm{Ba}(\mathrm{OH})_{2} / \mathrm{TiO}_{2}(\mu \mathrm{m}$ sized $\mathrm{TiO}_{2}$ powder) suspension was prepared, mixed with a certain amount of $\mathrm{BaTiO}_{3}$ powder, followed by compaction. The samples subjected to CS at $180{ }^{\circ} \mathrm{C} / 3 \mathrm{~h}$ resulted in high densification (94.4\%). However, $\mathrm{BaTiO}_{3}$ samples produced by CS had cubic crystal structure and/or amorphous grain boundaries, making the piezoelectric properties inadequate. Accordingly, an additional annealing process $\left(\mathrm{T}=900{ }^{\circ} \mathrm{C} / 3 \mathrm{~h}\right.$ ) to transform the crystal structure into the tetragonal one was conducted and the piezoelectric properties were improved, as shown in Fig. 9(a and b) [203,208].

In a slightly different study, the authors demonstrated the ability to print and cold sinter $\mathrm{Li}_{2} \mathrm{MoO}_{4}$ capacitor structures on both Nickel foil and PET film at low temperatures which would be complicated due to Nickel oxidation above $300{ }^{\circ} \mathrm{C}$ by conventional techniques. The study showed the possibility to sinter such composite systems and obtain additional process functionality (see later for co-sintering) [216]. Similar studies have been performed for $\mathrm{Li}_{1.5} \mathrm{Al}_{0.5} \mathrm{Ge}_{1.5}\left(\mathrm{PO}_{4}\right)_{3}$ [217] and $\mathrm{Ca}_{3} \mathrm{Co}_{4} \mathrm{O}_{9}$ [218]. $\mathrm{LiFePO}_{4}$ ceramics used as a cathode material for rechargeable batteries were produced by CS as well. LiOH aqueous solution was used for the process and relative densities above $89 \%$ were obtained at sintering temperatures around $240{ }^{\circ} \mathrm{C}[219,220]$. A recent review described the possible implementation of CS for solid-state lithium batteries, and highlighted the great potential of the process for battery and solid electrolyte production [221].

A variant approach of CS called cold co-sintering was developed recently [256]. In this process, ceramic-polymer composites were formed by sintering the ceramic material with desired thermoplastic polymer being the minor volume component. Such system gave additional design freedom to generate functional composites. In addition, CS was used as a low temperature ceramic bonding/fusing technique that can resists to elevated temperatures, and the method is called as cold

Table 2

Materials produced by room-temperature densification method, the processing conditions, some of the extracted properties and application areas.

\begin{tabular}{|c|c|c|c|c|c|}
\hline Materials & Application & Processing conditions & Properties & Relative density (\%) & Ref. \\
\hline $\mathrm{Al}_{2} \mathrm{O}_{3}$ & General & $1-5.6 \mathrm{GPa}$ & $\mathrm{H}_{\mathrm{v}}=5.7 \mathrm{GPa}$ & $\sim 90$ & [190] \\
\hline $\mathrm{CaCO}_{3}$ & General & $\begin{array}{l}500 \mathrm{MPa} \\
34 \mathrm{~min}\end{array}$ & $\begin{array}{l}\sigma_{\mathrm{c}}=225 \mathrm{MPa} \\
\mathrm{E}=30 \mathrm{GPa}\end{array}$ & $\sim 87$ & [35] \\
\hline $\mathrm{Li}_{2} \mathrm{MoO}_{4}$ & Dielectric & $30-130 \mathrm{MPa}$ & $\varepsilon_{\mathrm{r}}=4.6-5.2$ & $\sim 84-93$ & {$[58]$} \\
\hline $\mathrm{Li}_{2} \mathrm{MoO}_{4}-\mathrm{TiO}_{2} / \mathrm{BaTiO}_{3} / \mathrm{MnZn}$ Ferrite & Dielectric & $150 \mathrm{MPa}$ & $\varepsilon_{\mathrm{r}}=6.9-22.7$ & $86-90$ & [193-195] \\
\hline $\mathrm{Li}_{2} \mathrm{MoO}_{4}-\mathrm{Ba}_{0.55} \mathrm{Sr}_{0.45} \mathrm{TiO}_{3} / \mathrm{PZT}$ & Electrical & $250 \mathrm{MPa}$ & $\begin{array}{l}\varepsilon_{\mathrm{r}} \sim 200 \\
\mathrm{~d}_{33}=84 \mathrm{pC} / \mathrm{N} \\
\mathrm{g}_{33}=33 \mathrm{mVm} / \mathrm{N}\end{array}$ & $\sim 90$ & {$[199,200]$} \\
\hline $\mathrm{NaCl}$ & Dielectric & $\begin{array}{l}5-300 \mathrm{MPa} \\
0-24 \mathrm{~h}\end{array}$ & $\varepsilon_{\mathrm{r}} \sim 5.6$ & 〜90-99 & {$[201,202]$} \\
\hline $\begin{array}{l}\mathrm{SiO}_{2} \\
\mathrm{SiO}_{2}\end{array}$ & $\begin{array}{l}\text { General } \\
\text { General }\end{array}$ & $\begin{array}{l}1-7.7 \mathrm{GPa} \\
300 \mathrm{MPa} \\
5-60 \mathrm{~min}\end{array}$ & $\begin{array}{l}\mathrm{H}_{\mathrm{v}}=4-4.2 \mathrm{GPa} \\
\mathrm{H}_{\mathrm{v}} \sim 1.4 \mathrm{GPa}\end{array}$ & $\begin{array}{l}\sim 86 \\
\sim 99\end{array}$ & $\begin{array}{l}{[190-192]} \\
{[198]}\end{array}$ \\
\hline
\end{tabular}

$\varepsilon_{\mathbf{r}}$ : Relative permittivity, $\boldsymbol{\sigma}_{\mathbf{c}}$ : Compressive strength, E: Elastic modulus, $\mathbf{H}_{\mathbf{v}}$ : Vickers hardness, $\mathbf{d}_{\mathbf{3} 3}$ : Piezoelectric coefficient, $\mathbf{g}_{\mathbf{3 3}}$ : Voltage constant. 

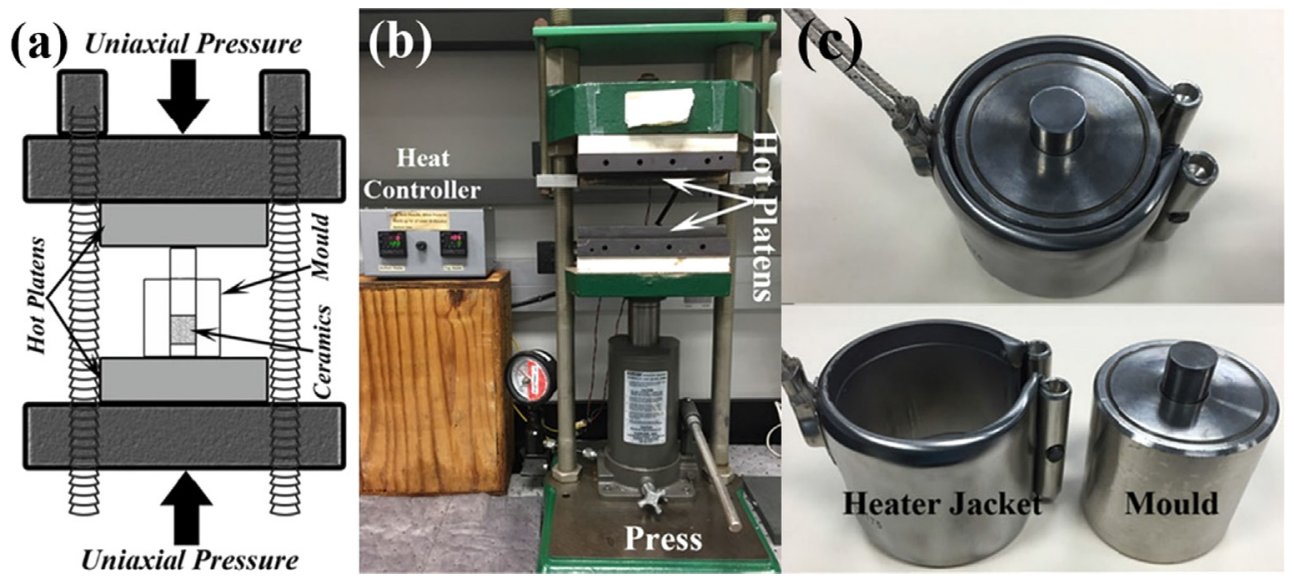

Fig. 7. Equipment used for cold sintering process: (a) simple press drawing, (b) the actual used CS instrument, and (c) the mould and heater jacket used for CS (Reproduced from [60], with permission from John Wiley and Sons, Copyright 2016).

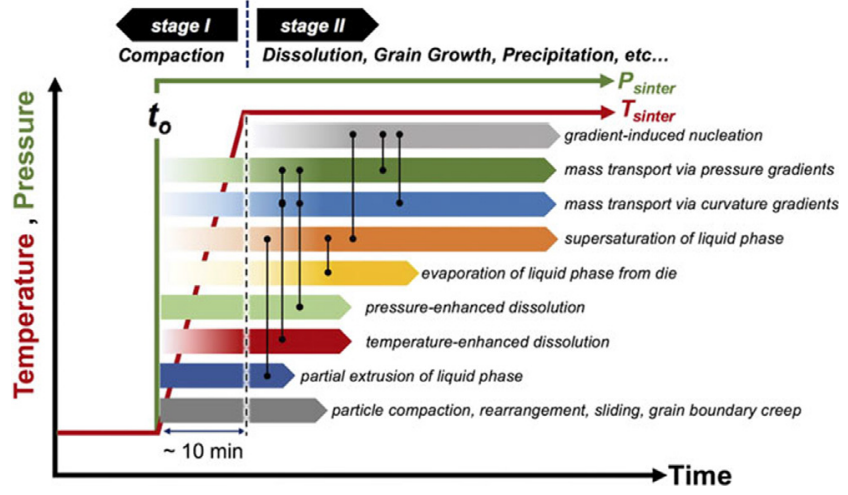

Fig. 8. Schematic representation of cold sintering process (Reproduced from [201], with permission from Cambridge University Press, Copyright 2017).

sintering ceramic bonding (CSCB) [257].

\subsection{Warm press}

Similar to CS, a uniaxial press is used for the warm press (WP) technique. The main difference, simply, lies in the application of the heat. While in CS a jacket surrounding the die heats the system, in WP both top and bottom platens of the pressing device $(<300 \mathrm{MPa}$ ) have electrical resistance (temperature reaching around $300{ }^{\circ} \mathrm{C}$ ) resembling conventional hot press, see Fig. 10 for the used equipment [258].

A mixture of fly ash, $\mathrm{NaOH}$ solution and sodium water glass was heated to $130{ }^{\circ} \mathrm{C} / 2 \mathrm{~h}$ under $200 \mathrm{MPa}$ pressure. The formed components had $71 \%$ relative density and high compressive strength values reaching $149 \mathrm{MPa}[59,259]$. It is known that dense calcium hydroxide body (slaked lime plaster) is hard to obtain by conventional sintering approaches. Calcium hydroxide was compressed uniaxially under 60-240 MPa while heated in between 100 and $250{ }^{\circ} \mathrm{C}$. Under such processing conditions dehydration of lime (or the moisture in the air) assisted the sintering, leading dissolution-precipitation reaction in slaked lime pseudo-sintering, similar to what is observed in CS studies. The sample under $240 \mathrm{MPa}$ pressure at $150{ }^{\circ} \mathrm{C}$ for $90 \mathrm{~min}$ sintering, gave a relative density of $81 \%$ and compressive strength of $57 \mathrm{MPa}$ [258]. In Table 4 ceramic compositions currently produced by WP, processing conditions and the obtained properties are given.

$\mathrm{CaCO}_{3}$ powder alone or mixed with $10 \mathrm{wt} \%$ water was compressed under a pressure of $240 \mathrm{MPa}$ at 150 to $280{ }^{\circ} \mathrm{C}$. Samples with a relative density of $87 \%$, and compressive strength of $40 \mathrm{MPa}$ was obtained after 180 min of WP at $150{ }^{\circ} \mathrm{C}$, see Fig. $11(\mathrm{a}-\mathrm{c})$ for the microstructural evolution [260]. In another study, geopolymer-SiC components were produced by using geo-polymer as a binder. At the end of $30 \mathrm{~min}$ at $130{ }^{\circ} \mathrm{C}$ under a pressure of $240 \mathrm{MPa}$, depending on the initial precursor type, relative densities reaching to $90 \%$ (having around $170 \mathrm{MPa}$ compressive strength) was able to be achieved [261].

\subsection{Reactive hydrothermal liquid phase densification}

Compared to above mentioned techniques, reactive hydrothermal liquid phase densification (rHLPD) process is a different low temperature densification concept [61]. The technique is based on the hydrothermal reaction, infiltration, reactive crystallization and liquid phase sintering principles. Fig. 12 gives the schematic representation of the process. In the study to produce $\mathrm{BaTiO}_{3}$ monoliths, green $\mathrm{TiO}_{2}$ bodies were prepared and infiltrated with $\mathrm{Ba}(\mathrm{OH})_{2} / \mathrm{H}_{2} \mathrm{O}$ solution. Subsequently, the system was subjected to a hydrothermal reaction at temperatures in between 90 and $240^{\circ} \mathrm{C}$ up to $72 \mathrm{~h}$. $\mathrm{BaTiO}_{3} / \mathrm{TiO}_{2}$ (residual titania was found to be below $<5 \%$ ) ceramics with relative densities around $90 \%$ was obtained.

In rHLPD, there is no application of pressure which assists densification, so the center of the particles does not get closer by the effect of externally applied pressure. There is actually a need for hydrothermal crystallization reaction with products having higher molar volume (compared to green body), such the one given in Reaction (II). In the case of the Reaction (II) resulting in $100 \%$ yield, the $\mathrm{TiO}_{2}$ molar volume $\left(20.2 \mathrm{~cm}^{3} / \mathrm{mol}\right)$ expands $91.6 \%$ while transforming into Barium titanate (molar volume of $38.7 \mathrm{~cm}^{3}$ ). Such volume change (expansion) fills the pore spaces and results in densification. With this technology, various systems including $\mathrm{SrTiO}_{3}\left[\mathrm{TiO}_{2}\right], \quad \mathrm{Ca}\left(\mathrm{PO}_{4}\right) \mathrm{F}_{2}\left[\mathrm{CaF}_{2}\right], \quad \mathrm{Sr}\left(\mathrm{PO}_{4}\right)$ $(\mathrm{OH})_{2}\left[\mathrm{SrTiO}_{3}\left[\mathrm{TiO}_{2}\right]\right], \quad \mathrm{CaC}_{2} \mathrm{O}_{4} / \mathrm{Ca}(\mathrm{OH})_{2}, \mathrm{CaCO}_{3}-\mathrm{SiO}_{2}\left[-\mathrm{CaSiO}_{3}\right]$ and other similar composite systems can be produced [262].

$\mathrm{Ba}(\mathrm{OH})_{2(\text { sol })}+\mathrm{TiO}_{2(\mathrm{~s})}=\mathrm{BaTiO}_{3(\mathrm{~s})}+\mathrm{H}_{2} \mathrm{O}_{(\mathrm{l})}$

\section{Comparison of the low temperature densification methods}

For the techniques discusses above, the processing conditions (applied pressure and temperature) were analyzed and plotted in Fig. 13. In the top-right inset of the figure, a magnified area of $\mathrm{P}<1000 \mathrm{MPa}$ $\& \mathrm{~T}<400{ }^{\circ} \mathrm{C}$ is shown, and as one could see the major part of the studies were actually conducted in this zone, outlining the boundary conditions for low temperature densification methods.

Although HRS is one of the earliest techniques, it utilizes a metal powder or chips that are oxidized under hydrothermal conditions by supercritical water in a capsule under mild pressures (100 MPa) and $\mathrm{mid} /$ high temperatures $\left(1000{ }^{\circ} \mathrm{C}\right)$. The process consumes less energy compared to conventional sintering of the same composition, and it 
Table 3

Materials produced by cold sintering method, the processing conditions, some of the extracted properties and application areas.

\begin{tabular}{|c|c|c|c|c|c|}
\hline Materials & Application & $\begin{array}{l}\text { Processing } \\
\text { conditions }\end{array}$ & Properties & Relative density (\%) & Ref. \\
\hline AgI & Electrical & N.A. & N.A. & N.A. & {$[201]$} \\
\hline $\mathrm{AgVO}_{3}$ & Optical & N.A. & N.A. & N.A. & {$[201]$} \\
\hline$\alpha-\mathrm{Al}_{2} \mathrm{O}_{3}$ & - & N.A. & N.A. & N.A. & {$[201]$} \\
\hline $\mathrm{Al}_{2} \mathrm{O}_{3}-\mathrm{NaCl}$ & Dielectric & $\begin{array}{l}120^{\circ} \mathrm{C} \\
200 \mathrm{MPa} \\
50 \mathrm{~min}\end{array}$ & $\begin{array}{l}\varepsilon_{\mathrm{r}} \sim 6.5, \tan \delta=0.007 \\
@ 1 \mathrm{MHz} \\
\varepsilon_{\mathrm{r}} \sim 6.0, \tan \delta=0.002 \\
@ 5 \mathrm{GHz}\end{array}$ & 96 & {$[222]$} \\
\hline $\mathrm{Al}_{2} \mathrm{SiO}_{5}-\mathrm{NaCl}$ & Dielectric & $\begin{array}{l}120^{\circ} \mathrm{C} \\
200 \mathrm{MPa} \\
50 \mathrm{~min}\end{array}$ & $\begin{array}{l}\varepsilon_{\mathrm{r}} \sim 5.4, \tan \delta=0.005 \\
@ 1 \mathrm{MHz} \\
\varepsilon_{\mathrm{r}} \sim 4.7, \tan \delta=0.002 \\
@ 1 \mathrm{MHz}\end{array}$ & N.A. & [223] \\
\hline $\mathrm{BaMoO}_{4}$ & Optical & N.A. & N.A. & N.A. & {$[201]$} \\
\hline $\mathrm{BaTiO}_{3}$ & Ferroelectric & $\begin{array}{l}180{ }^{\circ} \mathrm{C} \\
430 \mathrm{MPa} \\
1-180 \mathrm{~min}\end{array}$ & $\begin{array}{l}\varepsilon_{\mathrm{r}}=2332, \tan \delta=0.01 \\
@ 10^{-3} \mathrm{MHz} \text { after HT @ } 900{ }^{\circ} \mathrm{C}\end{array}$ & $\sim 80-97^{*}$ & {$[60,203,208,213]$} \\
\hline $\mathrm{Bi}_{2} \mathrm{O}_{3}$ & Electrical & N.A. & N.A. & N.A. & {$[201]$} \\
\hline $\mathrm{Bi}_{2} \mathrm{Te}_{3}$ & Thermoelectric & N.A. & N.A. & N.A. & {$[201]$} \\
\hline $\mathrm{BiVO}_{4}$ & Photocatalyst & N.A. & N.A. & N.A. & {$[201]$} \\
\hline$\left(\mathrm{Bi}_{0.95} \mathrm{Li}_{0.05}\right)\left(\mathrm{V}_{0.9} \mathrm{Mo}_{0.1}\right) \mathrm{O}_{4}-\mathrm{Na}_{2} \mathrm{Mo}_{2} \mathrm{O}_{7}$ & Dielectric & $\begin{array}{l}150{ }^{\circ} \mathrm{C} \\
200 \mathrm{MPa} \\
30 \mathrm{~min}\end{array}$ & $\varepsilon_{\mathrm{r}}=40-48, \tan \delta=0.0012$ & $95-96$ & [224] \\
\hline $\mathrm{Ca}_{3} \mathrm{Co}_{4} \mathrm{O}_{9}$ & Thermoelectric & $\begin{array}{l}135-350{ }^{\circ} \mathrm{C} \\
350 \mathrm{MPa} \\
60 \mathrm{~min}\end{array}$ & $\lambda=41 \mathrm{~S} / \mathrm{cm}$ & $\sim 85-90$ & {$[218]$} \\
\hline $\mathrm{Ca}_{5}\left(\mathrm{PO}_{4}\right)_{3}(\mathrm{OH})$ & Medical & N.A. & N.A. & N.A. & {$[201]$} \\
\hline $\mathrm{Ca}_{5}\left(\mathrm{PO}_{4}\right)_{3}(\mathrm{OH})$ & Environmental & $\begin{array}{l}200{ }^{\circ} \mathrm{C} \\
500 \mathrm{MPa} \\
10 \mathrm{~min}\end{array}$ & $\begin{array}{l}\mathrm{H}_{\mathrm{v}}=2.2-2.6 \mathrm{GPa} \\
\sigma_{\mathrm{c}} \sim 175 \mathrm{MPa}\end{array}$ & $\sim 95-97$ & [225-227] \\
\hline $\mathrm{CeO}_{2}$ & General & $\begin{array}{l}180{ }^{\circ} \mathrm{C} \\
500 \mathrm{MPa} \\
24 \mathrm{~h}\end{array}$ & $\mathrm{Ea}=1.13 \mathrm{eV}$ & $\sim 70$ & {$[228]$} \\
\hline $\mathrm{CsBr}$ & Optical & N.A. & N.A. & N.A. & {$[201]$} \\
\hline $\mathrm{CsH}_{2} \mathrm{PO}_{4}$ & Energy & $\begin{array}{l}120-200{ }^{\circ} \mathrm{C} \\
300 \mathrm{MPa} \\
1 \mathrm{~h}\end{array}$ & $\begin{array}{l}\mathrm{Ea}=0.38-0.4 \mathrm{eV} \\
\lambda=2.3 \times 10^{-4} \mathrm{~S} / \mathrm{cm} \text { at } 200{ }^{\circ} \mathrm{C}\end{array}$ & $93-98$ & [229] \\
\hline $\mathrm{CsSO}_{4}$ & Catalyst & N.A. & N.A. & N.A. & {$[201]$} \\
\hline $\mathrm{Cs}_{2} \mathrm{WO}_{4}$ & Insulator & N.A. & N.A. & N.A. & {$[201]$} \\
\hline $\mathrm{CuCl}$ & General & N.A. & N.A. & N.A. & {$[201]$} \\
\hline $\mathrm{Gd}_{2}\left(\mathrm{MoO}_{4}\right)_{3}$ & Ferroelectric & N.A. & N.A. & N.A. & {$[201]$} \\
\hline $\mathrm{InGaZnO}_{4}$ & Electrical & $\begin{array}{l}25-180{ }^{\circ} \mathrm{C} \\
100-350 \mathrm{MPa} \\
10 \mathrm{~min}\end{array}$ & N.A. & $\begin{array}{l}\sim 92-99 \text { After } \\
\mathrm{HT}=1200{ }^{\circ} \mathrm{C}\end{array}$ & [230] \\
\hline $\mathrm{KH}_{2} \mathrm{PO}_{4}$ & Ferroelectric & $\begin{array}{l}120{ }^{\circ} \mathrm{C} \\
350 \mathrm{MPa} \\
30 \mathrm{~min}\end{array}$ & N.A. & $>98$ & {$[60]$} \\
\hline $\mathrm{K}_{2} \mathrm{Mo}_{2} \mathrm{O}_{7}$ & Dielectric & $\begin{array}{l}120{ }^{\circ} \mathrm{C} \\
350 \mathrm{MPa} \\
15-20 \mathrm{~min}\end{array}$ & $\varepsilon_{\mathrm{r}}=9.8, \tan \delta=0.00083$ & $\sim 94$ & {$[204,231]$} \\
\hline $\mathrm{K}_{0.5} \mathrm{Na}_{0.5} \mathrm{NbO}_{3}$ & Piezoelectric & $\begin{array}{l}120{ }^{\circ} \mathrm{C} \\
350 \mathrm{MPa} \\
30 \mathrm{~min}\end{array}$ & $\mathrm{~d}_{33}=131 \mathrm{pC} / \mathrm{N}$ after HT @ $1115{ }^{\circ} \mathrm{C}$ & $\sim 65$ & {$[232]$} \\
\hline $\mathrm{KPO}_{3}$ & General & N.A. & N.A. & N.A. & {$[201]$} \\
\hline $\mathrm{LiAl}_{0.5} \mathrm{Ge}_{1,5}\left(\mathrm{PO}_{4}\right)_{3}$ & Energy storage & $\begin{array}{l}120{ }^{\circ} \mathrm{C} \\
400 \mathrm{MPa} \\
20 \mathrm{~min}\end{array}$ & $\begin{array}{l}\lambda=5.4 \times 10^{-5} \mathrm{~S} / \mathrm{cm} @ 25^{\circ} \mathrm{C} \text { after HT } \\
@ 650{ }^{\circ} \mathrm{C}\end{array}$ & 79 & {$[217]$} \\
\hline $\mathrm{Li}_{1.5} \mathrm{Al}_{0.5} \mathrm{Ge}_{1.5}\left(\mathrm{PO}_{4}\right)_{3} /$ & Energy storage & $\begin{array}{l}130{ }^{\circ} \mathrm{C} \\
380-620 \mathrm{MPa}\end{array}$ & $\lambda=2.3 \times 10^{-4} \mathrm{~S} / \mathrm{cm}$ at $\mathrm{RT}$ & $\sim 90$ & [233] \\
\hline $\begin{array}{l}\mathrm{Li}_{1+x+y} \mathrm{Al}_{\mathrm{x}} \mathrm{Ti}_{2-x} \mathrm{Si}_{y} \mathrm{P}_{3-y} \mathrm{O}_{12} \text { - LiTFSI } \\
(\mathrm{LiBi})_{0.5} \mathrm{MoO}_{4}\end{array}$ & Dielectric & $\begin{array}{l}2 \mathrm{~h} \\
\mathrm{RT}-120{ }^{\circ} \mathrm{C} \\
250-350 \mathrm{MPa} \\
20 \mathrm{~min}\end{array}$ & $\varepsilon_{\mathrm{r}}=33.7-37.1$ & $\sim 88-89$ & {$[231]$} \\
\hline $\begin{array}{l}\mathrm{Li}_{0,5 \mathrm{x}} \mathrm{Bi}_{1-0,5 \mathrm{x}} \mathrm{Mo}_{\mathrm{x}} \mathrm{V}_{1-\mathrm{x}} \mathrm{O}_{4} \\
(1-\mathrm{x})(\mathrm{LiBi})_{0.5} \\
\quad \mathrm{MoO}_{4} \text {-xPTFE }\end{array}$ & $\begin{array}{l}\text { Dielectric } \\
\text { Dielectric }\end{array}$ & $\begin{array}{l}\text { N.A. } \\
\text { RT- } 120{ }^{\circ} \mathrm{C} \\
250-350 \mathrm{MPa} \\
20 \mathrm{~min}\end{array}$ & $\begin{array}{l}\text { N.A. } \\
\varepsilon_{\mathrm{r}} \sim 10-40\end{array}$ & $\begin{array}{l}\text { N.A. } \\
>85\end{array}$ & $\begin{array}{l}{[201]} \\
{[231]}\end{array}$ \\
\hline $\mathrm{Li}_{2} \mathrm{CO}_{3}$ & General & N.A. & N.A. & N.A. & [201] \\
\hline $\mathrm{LiCoPO}_{4}$ & Energy storage & N.A. & N.A. & N.A. & [201] \\
\hline $\mathrm{LiFePO}_{4}-\mathrm{CNF}$ & Energy storage & $\begin{array}{l}180{ }^{\circ} \mathrm{C} \\
240 \mathrm{MPa} \\
10 \mathrm{~min}\end{array}$ & $\begin{array}{l}\mathrm{VC}=373 \mathrm{mAh} / \mathrm{cm}^{3} \\
@ 0.1 \mathrm{C} \text { (discharge rate) }\end{array}$ & $\sim 70$ & [220] \\
\hline
\end{tabular}


Table 3 (continued)

\begin{tabular}{|c|c|c|c|c|c|}
\hline Materials & Application & $\begin{array}{l}\text { Processing } \\
\text { conditions }\end{array}$ & Properties & Relative density (\%) & Ref. \\
\hline $\mathrm{LiFePO}_{4}-\mathrm{PVDF}-\mathrm{C}$ & Energy storage & $\begin{array}{l}240{ }^{\circ} \mathrm{C} \\
30-750 \mathrm{MPa} \\
30 \mathrm{~min}\end{array}$ & $\begin{array}{l}\mathrm{VC} \sim 340 \mathrm{mAh} / \mathrm{cm}^{3} \\
@ 0.03-0.1 \mathrm{C}\end{array}$ & $\sim 89$ & [219] \\
\hline $\mathrm{Li}_{2} \mathrm{Mg}_{3} \mathrm{TiO}_{6}$ & Dielectric & $\begin{array}{l}180{ }^{\circ} \mathrm{C} \\
300 \mathrm{MPa} \\
1 \mathrm{~h}\end{array}$ & $\begin{array}{l}\varepsilon_{\mathrm{r}}=15.51-15.68 \text { after HT } @ \\
800-950{ }^{\circ} \mathrm{C}\end{array}$ & $\sim 90$ & {$[234]$} \\
\hline $\mathrm{Li}_{2} \mathrm{MoO}_{4}$ & Dielectric & $\begin{array}{l}120{ }^{\circ} \mathrm{C} \\
37-74 \mathrm{MPa} \\
15-20 \mathrm{~min}\end{array}$ & $\varepsilon_{\mathrm{r}}=5.6$ & $\sim 96$ & [231] \\
\hline $\mathrm{Li}_{2} \mathrm{MoO}_{4}$-PTFE & Dielectric & $\begin{array}{l}120{ }^{\circ} \mathrm{C} \\
37-74 \mathrm{MPa} \\
15-20 \mathrm{~min}\end{array}$ & $\varepsilon_{\mathrm{r}}=5.8-2.9$ & $>90$ & [231] \\
\hline $\mathrm{Li}_{2} \mathrm{MoO}_{4}-\mathrm{BaFe}_{12} \mathrm{O}_{19}$ & Dielectric & $\begin{array}{l}120{ }^{\circ} \mathrm{C} \\
55-70 \mathrm{MPa} \\
10-40 \mathrm{~min}\end{array}$ & $\varepsilon_{\mathrm{r}}=5.6-5.8$ & $94-97$ & {$[235]$} \\
\hline $\mathrm{LiVO}_{3}$ & Energy storage & N.A. & N.A. & N.A. & [201] \\
\hline $\mathrm{Li}_{2} \mathrm{WO}_{4}$ & Catalyst & N.A. & N.A. & N.A. & {$[201]$} \\
\hline $\mathrm{MgO}$ & General & N.A. & N.A. & N.A. & [201] \\
\hline $\mathrm{Mg}_{2} \mathrm{P}_{2} \mathrm{O}_{7}$ & Biological & N.A. & N.A. & N.A. & [201] \\
\hline $\mathrm{MnO}$ & General & $\begin{array}{l}100-300{ }^{\circ} \mathrm{C} \\
530 \mathrm{MPa} \\
30-60 \mathrm{~min}\end{array}$ & N.A. & 94 & [207] \\
\hline $\mathrm{MoO}_{3}$ & Dielectric & $\begin{array}{l}120-150{ }^{\circ} \mathrm{C} \\
100-150 \mathrm{MPa} \\
10-30 \mathrm{~min}\end{array}$ & $\varepsilon_{\mathrm{r}}=9.91$ after HT $@ 700{ }^{\circ} \mathrm{C}$ & 77 & {$[201,236]$} \\
\hline $\mathrm{MoS}_{2}$-Graphite & Energy storage & $\begin{array}{l}140{ }^{\circ} \mathrm{C} \\
520 \mathrm{MPa} \\
1 \mathrm{~h}\end{array}$ & $\mathrm{SC}=950 \mathrm{mAh} / \mathrm{g}$ at $0.1 \mathrm{~A} / \mathrm{g}$ & 88 & [237] \\
\hline $\mathrm{Na}_{0.5} \mathrm{Bi}_{0.5} \mathrm{MoO}_{4}-\mathrm{Li}_{2} \mathrm{MoO}_{4}$ & Dielectric & $\begin{array}{l}150{ }^{\circ} \mathrm{C} \\
200 \mathrm{MPa} \\
30 \mathrm{~min}\end{array}$ & $\varepsilon_{\mathrm{r}} \sim 17.4, \tan \delta=0.0008$ & 〜93-96 & [238] \\
\hline $\mathrm{Na}_{0.5} \mathrm{Bi}_{0.5} \mathrm{TiO}_{3}$ & Piezoelectric & $\begin{array}{l}180{ }^{\circ} \mathrm{C} \\
200-550 \mathrm{MPa} \\
15-75 \mathrm{~min}\end{array}$ & $\begin{array}{l}\varepsilon_{\mathrm{r}}=681, \tan \delta=0.08 \\
\text { at } \mathrm{RT} \mathrm{d}_{33}=52.5 \mathrm{pC} / \mathrm{N} \text { after HT @ } \\
900{ }^{\circ} \mathrm{C}\end{array}$ & 74 & [239] \\
\hline $\mathrm{NaCl}$ & General & $\begin{array}{l}25-120{ }^{\circ} \mathrm{C} \\
300 \mathrm{MPa} \\
10 \mathrm{~min}\end{array}$ & $\varepsilon_{\mathrm{r}} \sim 5.9$ & 〜93-99 & {$[240]$} \\
\hline $\mathrm{Na}_{\mathrm{x}} \mathrm{CO}_{2} \mathrm{O}_{4}$ & Thermoelectric & N.A. & N.A. & N.A. & [201] \\
\hline $\mathrm{Na}_{3.256} \mathrm{Mg}_{0.128} \mathrm{Zr}_{1.872} \mathrm{Si}_{2} \mathrm{PO}_{12}$ & Energy storage & $\begin{array}{l}120-180{ }^{\circ} \mathrm{C} \\
300-780 \mathrm{MPa} \\
10-120 \mathrm{~min}\end{array}$ & $\begin{array}{l}\lambda \sim 1.4 \times 10^{-3} \mathrm{~S} / \mathrm{cm} \\
\lambda_{\mathrm{i}}=0.88 \mathrm{mS} / \mathrm{cm} \text { after HT } @ 1100{ }^{\circ} \mathrm{C}\end{array}$ & $\sim 83$ & [241] \\
\hline $\mathrm{Na}_{3.4} \mathrm{Sc}_{0.4} \mathrm{Zr}_{1.6} \mathrm{Si}_{2} \mathrm{PO}_{12}$ & - & $\begin{array}{l}250{ }^{\circ} \mathrm{C} \\
300 \mathrm{MPa} \\
10 \mathrm{~min}\end{array}$ & $\begin{array}{l}\lambda=10^{-6}-10^{-3} \mathrm{~S} / \mathrm{cm} \text { after HT } @ \\
200-1100{ }^{\circ} \mathrm{C}\end{array}$ & $\sim 82$ & [242] \\
\hline $\mathrm{Na}_{2} \mathrm{Mo}_{2} \mathrm{O}_{7}$ & Dielectric & $\begin{array}{l}120{ }^{\circ} \mathrm{C} \\
250-350 \mathrm{MPa} \\
15-20 \mathrm{~min}\end{array}$ & $\varepsilon_{\mathrm{r}}=13.4$ & $\sim 94$ & {$[231]$} \\
\hline $\mathrm{NaNbO}_{3}-\mathrm{PVDF}$ & Energy storage & $\begin{array}{l}180{ }^{\circ} \mathrm{C} \\
550 \mathrm{MPa} \\
10 \mathrm{~min}\end{array}$ & $\mathrm{E}_{\mathrm{b}}=1345 \mathrm{kV} / \mathrm{cm}$ & $\sim 97$ & [243] \\
\hline $\mathrm{NaNO}_{2}$ & Ferroelectric & N.A. & N.A. & 98 & {$[60]$} \\
\hline $\mathrm{NaNO}_{3}-\mathrm{Ca}(\mathrm{OH})_{2}$ & Energy storage & $\begin{array}{l}120{ }^{\circ} \mathrm{C} \\
500 \mathrm{MPa} \\
10 \mathrm{~min}\end{array}$ & $\begin{array}{l}\sigma_{\mathrm{c}} \sim 20-120 \mathrm{MPa} \\
\mathrm{E}_{\mathrm{es}}=59.48 \%\end{array}$ & N.A. & [244] \\
\hline $\mathrm{Na}_{2} \mathrm{WO}_{4}$ & Catalyst & N.A. & N.A. & N.A. & [201] \\
\hline $\mathrm{Na}_{2} \mathrm{ZrO}_{3}$ & Electrical & N.A. & N.A. & N.A. & [201] \\
\hline $\mathrm{PbTe}$ & Thermoelectric & N.A. & N.A. & N.A. & [201] \\
\hline $\mathrm{Pb}(\mathrm{Zr}, \mathrm{Ti}) \mathrm{O}_{3}$ & Ferroelectric & $\begin{array}{l}300{ }^{\circ} \mathrm{C} \\
500 \mathrm{MPa} \\
150 \mathrm{~min}\end{array}$ & $\begin{array}{l}\mathrm{d}_{33}=4 \mathrm{pC} / \mathrm{N} @ \mathrm{CSP} \\
\mathrm{d}_{33}=197 \mathrm{pC} / \mathrm{N} @ 900{ }^{\circ} \mathrm{C} \text { for } 3 \mathrm{~h}\end{array}$ & 89 & [214] \\
\hline $\mathrm{SnO}$ & Electrical & $\begin{array}{l}70-265{ }^{\circ} \mathrm{C} \\
350 \mathrm{MPa} \\
45 \mathrm{~min}\end{array}$ & $\lambda=0.01-0.02 \mathrm{~S} / \mathrm{cm}$ & $\sim 85$ & {$[245]$} \\
\hline $\mathrm{SrTiO}_{3}$ & Ferroelectric & $\begin{array}{l}180{ }^{\circ} \mathrm{C} \\
\leq 750 \mathrm{MPa} \\
60 \mathrm{~min}\end{array}$ & N.A. & $\begin{array}{l}\sim 96-97 \text { after } \\
\mathrm{HT}=950{ }^{\circ} \mathrm{C}\end{array}$ & [215] \\
\hline $\mathrm{TiO}_{2}$ & General & $\begin{array}{l}150{ }^{\circ} \mathrm{C} \\
250-500 \mathrm{MPa} \\
30 \mathrm{~min}\end{array}$ & $\mathrm{SSA}=117 \mathrm{~m}^{2} / \mathrm{g}$ & 68 & [246] \\
\hline $\begin{array}{l}\mathrm{V}_{2} \mathrm{O}_{3} \\
\mathrm{~V}_{2} \mathrm{O}_{5}\end{array}$ & $\begin{array}{l}\text { Electrical } \\
\text { Electrical }\end{array}$ & $\begin{array}{l}\text { N.A. } \\
120{ }^{\circ} \mathrm{C} \\
350 \mathrm{MPa} \\
20 \mathrm{~min}\end{array}$ & $\begin{array}{l}\text { N.A. } \\
\lambda=4.8 \times 10^{-4} \mathrm{~S} / \mathrm{cm} \\
\mathrm{E}_{\mathrm{a}} \sim 0.25 \mathrm{eV}\end{array}$ & $\begin{array}{l}\text { N.A. } \\
90.2\end{array}$ & $\begin{array}{l}{[201]} \\
{[201,247]}\end{array}$ \\
\hline
\end{tabular}


Table 3 (continued)

\begin{tabular}{|c|c|c|c|c|c|}
\hline Materials & Application & $\begin{array}{l}\text { Processing } \\
\text { conditions }\end{array}$ & Properties & Relative density (\%) & Ref. \\
\hline $\mathrm{V}_{2} \mathrm{O}_{5}-\mathrm{CNF}$ & Electrical & $\begin{array}{l}120{ }^{\circ} \mathrm{C} \\
350 \mathrm{MPa} \\
20 \mathrm{~min}\end{array}$ & $\begin{array}{l}\lambda=10-10^{2} \mathrm{~S} / \mathrm{cm} \\
\mathrm{VC}=800 \mathrm{mAh} / \mathrm{cm}^{3} @ \sim 0.2 \mathrm{C} \text {-Rate }\end{array}$ & $\sim 89$ & {$[248]$} \\
\hline $\mathrm{V}_{2} \mathrm{O}_{5}$-PEDOT-PSS & Electrical & $\begin{array}{l}120-140{ }^{\circ} \mathrm{C} \\
300-350 \mathrm{MPa} \\
20-45 \mathrm{~min}\end{array}$ & $\begin{array}{l}\lambda=10^{-3}-10^{-2} \mathrm{~S} / \mathrm{cm} \\
\mathrm{E}_{\mathrm{a}} \sim 0.2 \mathrm{eV} \\
\rho=6.34 \Omega \mathrm{m}\end{array}$ & $\sim 90$ & {$[249,250]$} \\
\hline $\mathrm{WO}_{3}$ & Electrical & N.A. & N.A. & N.A. & {$[201]$} \\
\hline $\mathrm{ZnMoO}_{4}$ & Electrical & N.A. & N.A. & N.A. & [201] \\
\hline $\mathrm{ZnO}$ & Thermoelectric & $\begin{array}{l}25-305{ }^{\circ} \mathrm{C} \\
0-530 \mathrm{MPa} \\
5-300 \mathrm{~min}\end{array}$ & $\begin{array}{l}\lambda=12 \mathrm{~S} / \mathrm{cm} \\
\sigma_{0} \sim 64.4 \mathrm{MPa} \\
\mathrm{m}=8.2\end{array}$ & $\sim 65-99$ & {$[205,207,218,251-253]$} \\
\hline $\mathrm{ZnO}-\mathrm{Ti}_{3} \mathrm{C}_{2} \mathrm{~T}_{\mathrm{x}}$ & Electrical & $\begin{array}{l}300{ }^{\circ} \mathrm{C} \\
250 \mathrm{MPa} \\
60 \mathrm{~min}\end{array}$ & $\begin{array}{l}\mathrm{Hv} \sim 2-5 \mathrm{GPa} \\
\mathrm{E} \sim 60-110 \mathrm{GPa} \\
\lambda=16 \mathrm{~S} / \mathrm{cm}\end{array}$ & $92-98$ & {$[254]$} \\
\hline ZnO-PTFE & Electrical & $\begin{array}{l}285^{\circ} \mathrm{C} \\
300 \mathrm{MPa} \\
60 \mathrm{~min}\end{array}$ & $\begin{array}{l}\alpha=3-7 \\
\mathrm{E}_{\mathrm{b}} \leq 3225 \mathrm{~V} / \mathrm{mm} \\
\mathrm{E}_{\mathrm{a}} \sim 0.8 \mathrm{eV}\end{array}$ & $>90$ & {$[255]$} \\
\hline ZnTe & Electrical & N.A. & N.A. & N.A. & [201] \\
\hline $\mathrm{ZrF}_{4}$ & Optical & N.A. & N.A. & N.A. & [201] \\
\hline $\mathrm{ZrO}_{2}$ & General & $\begin{array}{l}180{ }^{\circ} \mathrm{C} \\
350 \mathrm{MPa} \\
30-180 \mathrm{~min}\end{array}$ & $\begin{array}{l}\mathrm{Hv}=0.5 \mathrm{GPa} @ \mathrm{CSP} \\
\mathrm{Hv}=13.6 \mathrm{GPa} \text { after HT } @ 1200{ }^{\circ} \mathrm{C}\end{array}$ & $\sim 56-96$ & [209-211] \\
\hline
\end{tabular}

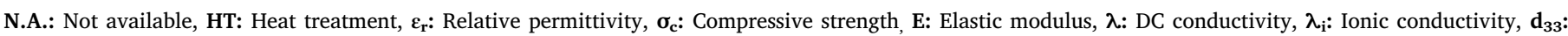

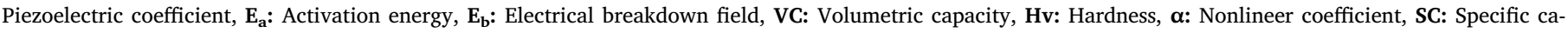
pacity, $\rho$ : Resistivity, Ees: Energy storage efficiency, m: Weibull modulus, $\sigma_{0}$ : Characteristic strength, ${ }^{*}$ Calculated

enables to sinter materials having high vapor pressure, phase transformation and/or high decomposition rate at sintering temperatures. The driving force of HRS is primarily an exothermic chemical reaction between metal particles and water as well as applied external pressure which increases contact area relative to the cross-sectional area of the metal particles. The liquid phase used for the production of the bulk material is used as a reactant for the oxidation of metal instead of only a mass transport media [53]. As a result of HRS the obtained sintered bodies have fine grained uniform microstructure, high purity and density. On the other hand, in some cases metal-hydride or oxide film formation may retard the sintering, besides it necessitates a specific instrument which clearly casts limitation on the sample size [69]. Moreover, there are uncertainties arising from lack of suffice information related with the purity, size and shape of raw materials, the ratio of metal to water, and other processing conditions (temperature, pressure, time, etc.) [263]. It is also important to note that chemical reactions occurring in HRS are exothermic processes: e.g. oxidation of metal, and thus the actual process temperatures could be much higher than those of the ones measured.

Broadly speaking, HHP is a more practical method to densify ceramics compared to HRS since the application parameters $\left(\mathrm{T}<350{ }^{\circ} \mathrm{C}\right.$,
$\mathrm{P}<25 \mathrm{MPa}, \mathrm{t}<2 \mathrm{~h}$ ) are milder. A suspension of powder is uniaxially consolidated in a heated pressing apparatus while the powder re-crystallizes hydrothermally. Normally, the products have relative densities $(<80 \%)$ [115], however, if the applied pressure is increased, e.g. ( $>80 \mathrm{MPa}$ ), highly dense (98.3\%) materials can be obtained [158]. For HHP, water is used as a transport media for species obtained by dissolving the raw powder. Successive re-crystallization in pore surfaces proceeds concurrent consolidation under the applied pressure. In this way, HHP is similar to pressure assisted techniques since they all require externally applied pressure and heat [201]. However similar to HRS, it necessitates a specialized equipment to ensure hydrothermal reaction conditions, limiting the sample size as well [61]. It should be noted that not only the monolithic ceramics, glasses and ceramic-metal composites were produced but also organic materials were processed by HHP [264-267]. Besides, the efforts to address environmental problems such as to recycling toxic and hazardous wastes or immobilization of heavy metals and low/high-level radioactive materials [268,269]. While for HHP and HRS a special reaction chamber is needed, for other low temperature densification methods, ordinary presses with heating elements can be used.

As name implies, RTD was conducted only at RT, this imposed
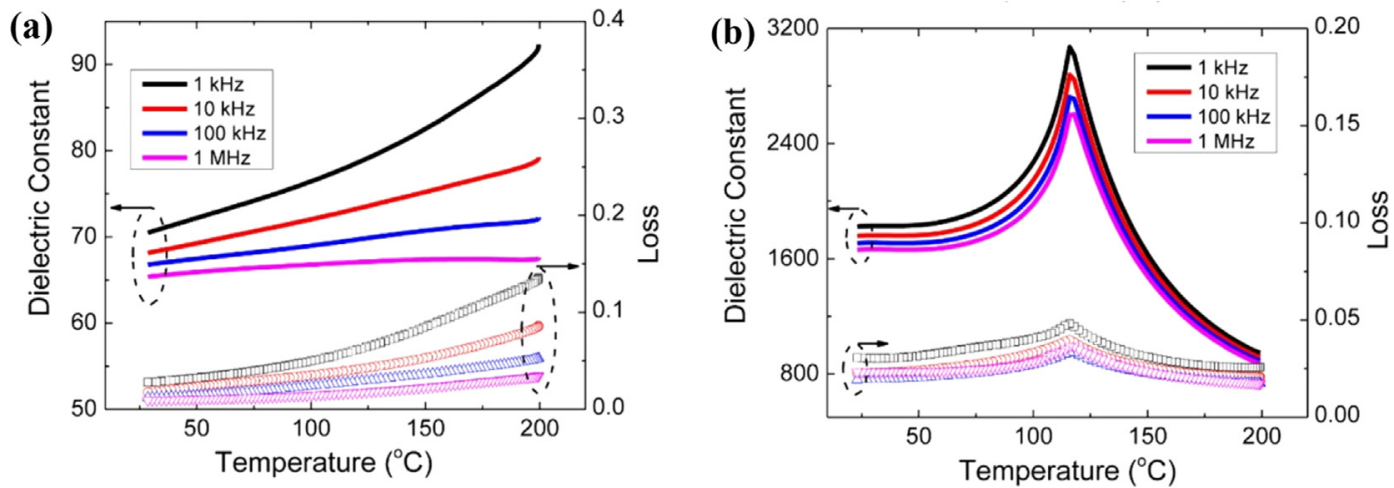

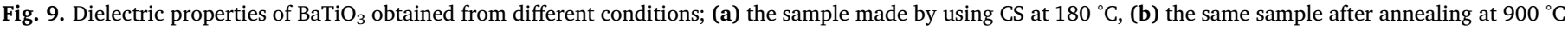
(Reprinted with permission from [203,208]. Copyright (2016) American Chemical Society). 


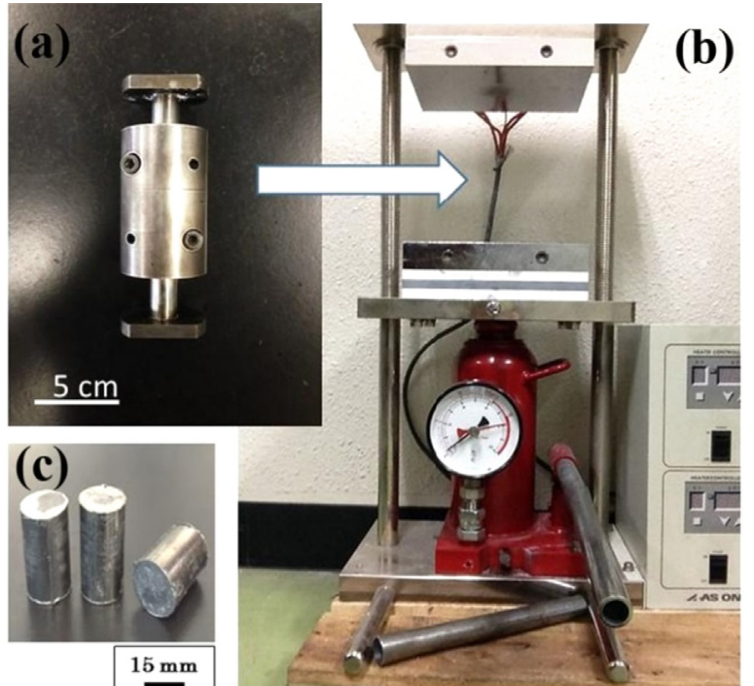

Fig. 10. Warm press equipment; (a) die, (b) press device, and (c) hardened bodies. (Reproduced from [259]).

higher pressure levels than CS and WP when the selected composition has low solubility. In fact, for all RTD, CS and WP processes at least a moderate solubility of the raw powder or high pressure levels to consolidate the green-body is needed.

In CS resistance jacket surrounding the reaction chamber was used for heating, and compared to WP, similar temperature ranges but higher pressure levels $(<1 \mathrm{GPa})$ were followed [201].

There are very limited published works in which a throughout comparison of CS and Hydrothermal sintering/HHP is given [270], and thus further studies are certainly required. Instrumental differences should be stated first since as known the device used for CS is basically as an 'open reactor' while HHP apparatus can be thought as a closed system to ensure the hydrothermal reaction conditions which affect densification rate and crystal growth. While both processes give similar densification trends and relative density values, suggesting analogous mechanical-chemical contributions, in the study to compare Hydrothermal sintering and CS of $\mathrm{ZnO}$ monoliths, the authors showed that these two processes differ in their chemical activities [270]. In fact under the same processing parameters (temperature, pressure, etc.), the outcome from those two processes might be different. Furthermore, highly congruent dissolution was found to be crucial for the high rate solution-precipitation process. Incongruent or limited dissolution was detrimental to obtain high density at low temperatures [215], and therefore such components should be additionally heat treated at elevated temperatures or similar strategy to rHLPD might be followed.

WP has great similarity with HHP and CS in terms of procedure
[260]. Usually, it is operated with the help of a solution (solutionprecipitation assisting medium) at temperatures $<300{ }^{\circ} \mathrm{C}$ under a constant uniaxial pressure (e.g. $<240 \mathrm{MPa}$ ) to densify the products. The heat is conducted axially through pressing plates similar to the direction of the applied pressure which is different for CS and HHP. Therefore, homogeneous heat distribution across the sample should be carefully regulated especially for thick components. While sample size is still a relevant concern, all these processes can be effectively used to produce porous ceramic and glass artifacts [246], or various composites (polymer/metal/ceramic) [256] extending the utilization of the techniques in wide range of application areas and industries.

The last method rHLPD is a reactive process in which the starting solid and liquid reacts to form a new, higher volume crystalline product. rHLPD enables densification in a hydrothermal reactor as a result of reaction and crystallization events, i.e. no pressure is applied during the process instead in all others there is an application of pressure throughout densification. By separating consolidation from the hydrothermal reaction step, a wide range of conventional forming technology can be used, allowing for great variety of shapes and sizes as well as being more amenable to mass production. Because no pressure is applied and densification occurs by reactive crystallization, the process does not induce shrinkage, so that large objects can be densified without probable distortion or cracking. The limitation of rHLPD system is based on the fact that there must be a net molar volume increase for densification to occur. Besides, unless the starting green body is made from a very fine or porous powder, it is hard to avoid composite formation even with extended sintering periods, indicating a limited application prospect when phase pure systems are considered.

It is worth mentioning that currently there are very few studies performed to produce a monolith having similar chemical composition by different low temperature densification approaches, and compare the observed properties, the economic and environmental impacts (e.g. carbon footprint) apart from a very recent works on comparison of CS with traditional techniques [271], and on theoretical analysis of the active mechanisms during cold sintering conducted both by isostatic or uniaxial pressure $[272,273]$. A very recent study reported the properties of zinc oxide $(\mathrm{ZnO})$ produced both by hydrothermal sintering and the cold sintering [270]. $\mathrm{CaCO}_{3}$ artifacts were produced via pressure assisted techniques by two different groups. Yamasaki et al. [56] used micron sized aragonite powder for HHP $\left(<300{ }^{\circ} \mathrm{C} \& \sim 65 \mathrm{MPa}\right.$ pressure) and demonstrated that the resulted tablets had $60 \mathrm{MPa}$ compressive strength. When chitosan was added to initial aragonite powder, the strength was improved to $\sim 160 \mathrm{MPa}$ at around $90 \%$ relative density [86]. Following these works, RTD was applied to consolidate nanosized vaterite under pressures below $800 \mathrm{MPa}$. Samples with $87 \%$ relative density and compressive strength of $225 \mathrm{MPa}$ were obtained. Although there are dissimilarities in the obtained properties, it is not easy to speculate on these results due to the discrepancies in the reported characterization data.

Table 4

Materials produced by warm press, the processing conditions, some of the extracted properties and application areas.

\begin{tabular}{|c|c|c|c|c|c|}
\hline Materials & Application & Processing conditions & Properties & Relative density (\%) & Ref. \\
\hline $\mathrm{CaCO}_{3}$ & General & $\begin{array}{l}150-280{ }^{\circ} \mathrm{C} \\
240 \mathrm{MPa} \\
10-180 \mathrm{~min}\end{array}$ & $\sigma_{\mathrm{c}} \sim<40 \mathrm{MPa}$ & $\sim 87$ & {$[260]$} \\
\hline $\mathrm{Ca}(\mathrm{OH})_{2}$ & General & $\begin{array}{l}100-250{ }^{\circ} \mathrm{C} \\
60-240 \mathrm{MPa} \\
10-180 \mathrm{~min}\end{array}$ & $\sigma_{\mathrm{c}} \sim 20-57 \mathrm{MPa}$ & $59-81$ & {$[258]$} \\
\hline Geopolymer & General & $\begin{array}{l}130-280{ }^{\circ} \mathrm{C} \\
200 \mathrm{MPa} \\
10-60 \mathrm{~min}\end{array}$ & $\sigma_{\mathrm{c}} \sim 20-150 \mathrm{MPa}$ & N.A. & {$[59,259]$} \\
\hline Geopolymer-SiC & General & $\begin{array}{l}130{ }^{\circ} \mathrm{C} \\
240 \mathrm{MPa} \\
30 \mathrm{~min}\end{array}$ & $\sigma_{\mathrm{c}} \sim 10-75 \mathrm{MPa}$ & $\sim 72-80$ & {$[261]$} \\
\hline
\end{tabular}

N.A.: Not available, $\boldsymbol{\sigma}_{\mathbf{c}}$ : Compressive strength. 


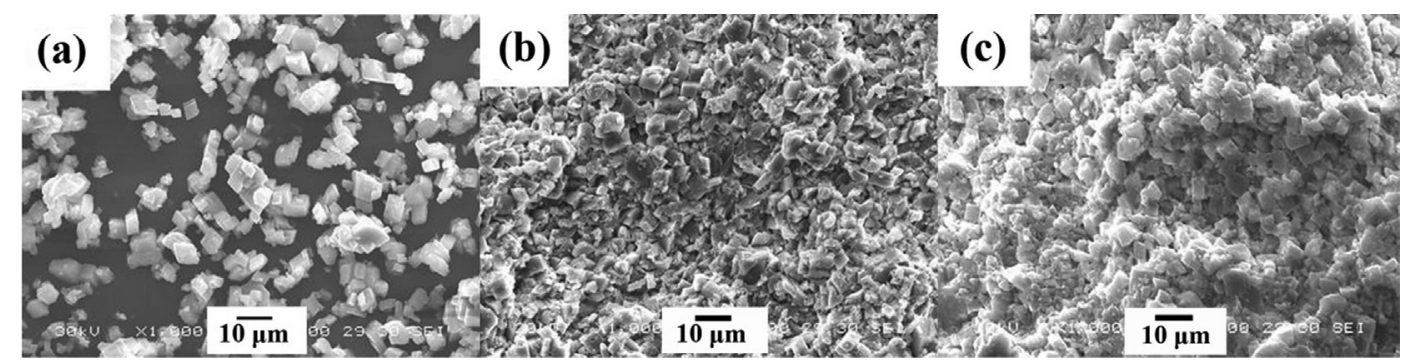

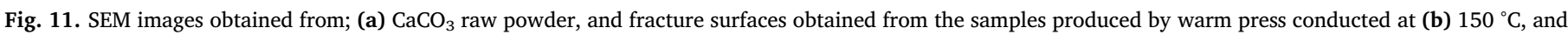
(c) at $280{ }^{\circ} \mathrm{C}$ (Reprinted from [260], Copyright (2017), with permission from Elsevier).

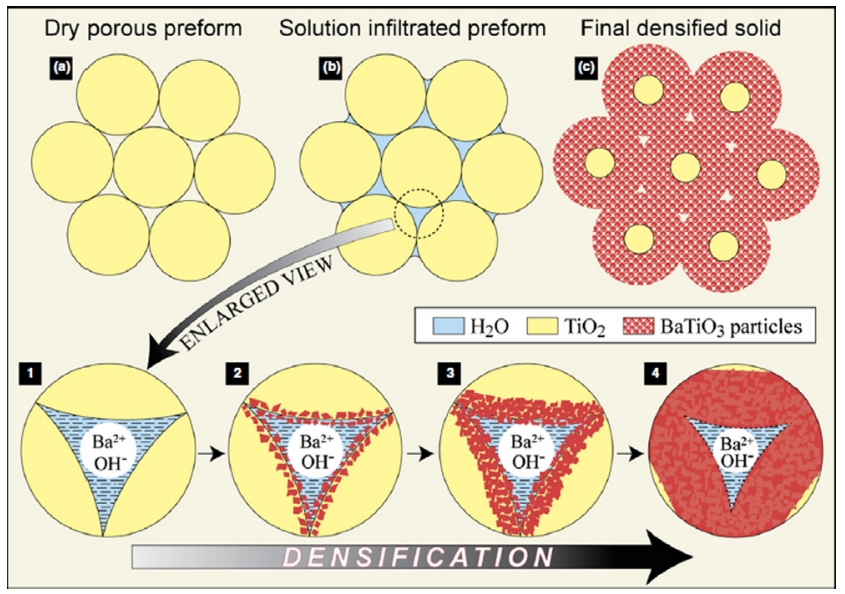

Fig. 12. Schematic representation of the reactive hydrothermal liquid phase densification process (Reproduced from [61], with permission from John Wiley and Sons, Copyright 2016).

\section{Concluding remarks}

Currently available low temperature densification (LTD) methods were classified into four main groups: (i) hydrothermal reaction sintering (HRS), (ii) hydrothermal hot pressing (HHP), (iii) pressure-assisted densification techniques: room-temperature densification (RTD), cold sintering (CS), warm press (WP), and finally (iv) reactive hydrothermal liquid phase densification (rHLPD). The densification mechanisms of these methods still have not been completely analyzed yet.
Aforementioned techniques are commonly assisted by an aqueous solution used as either reactant or transient liquid phase to assist densification. Another most notable similarity in HHP, RTD, CS, WP and rHLPD is that they all involve series of solution-precipitation events, throughout densification. All these methods take place at relatively lower temperatures and higher pressures compared to those for conventional sintering (excluding pressure assisted ones).

It should be recalled that currently there are very limited studies performed to compare the properties of a same-single component (preferably having similar relative density, grain size, etc.) produced by using all currently known low temperature densification approaches, yet. When the compositions given in the tables are analyzed, it can be seen that, in general, oxides (mostly to be used as electro-ceramics) were produced under such low temperature and mild/high pressure levels, and therefore further studies are still necessary to explore novel methods and/or compositions such as carbides. Furthermore, the implementation of these low temperature densification processes as industrial manufacturing technologies poses challenges to ceramic industry using conventional sintering since new instruments are needed to be installed.

\section{Declaration of Competing Interest}

The authors declare that they have no known competing financial interests or personal relationships that could have appeared to influence the work reported in this paper.

\section{Acknowledgement}

The authors gratefully acknowledge the support of TUBITAK (The

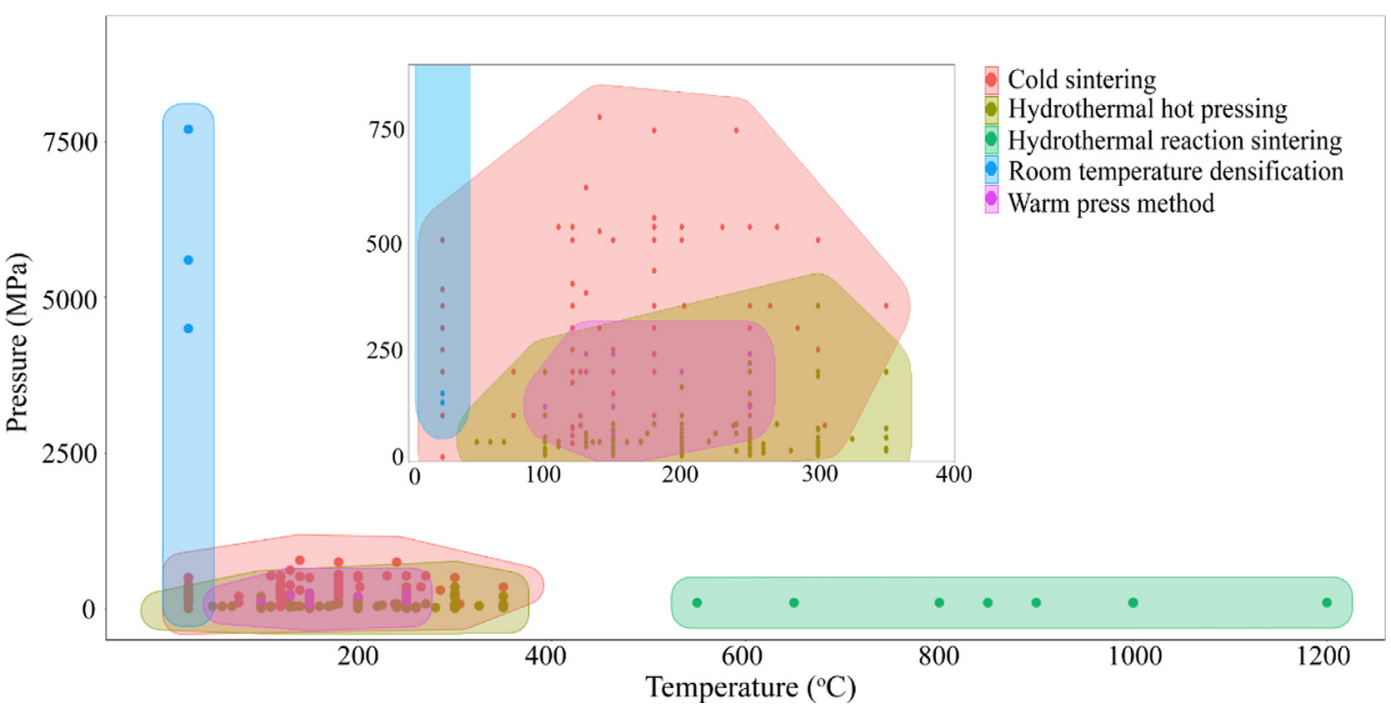

Fig. 13. Applied pressure $(\mathrm{P}=\mathrm{MPa})$ versus temperature $\left(\mathrm{T}={ }^{\circ} \mathrm{C}\right)$ chart which was made by using RStudio software's Ggforce module with the data collected from the published papers. In the top-right inset, magnified area of $\mathrm{T}<400{ }^{\circ} \mathrm{C}$ is given. 
Scientific and Technological Research Council of Turkey) under the project Grant No: 218M342. The authors would also like to thank Tugce Semerci, Ezgi Ogur, and Cerem Piskin (Department of Materials Science and Engineering, Izmir Institute of Technology) for their helps during the preparation of schematics.

\section{References}

[1] R.F. Walker, Mechanism of material transport during sintering, J. Am. Ceram. Soc. 38 (1955) 187-197, https://doi.org/10.1111/j.1151-2916.1955.tb14928.x.

[2] M.N. Rahaman, Sintering of Ceramics, CRC Press, 2007.

[3] R.M. German, Sintering Theory and Practice, Wiley, 1996.

[4] M.N. Rahaman, Sintering theory and fundamentals, in: P. Samal, J. Newkirk (Eds.), Powder Metall, ASM International, 2015.

[5] P.B. Vandiver, O. Soffer, B. Klima, J. Svoboda, The origins of ceramic technology at Dolní Věstonice, Czechoslovakia, Science 246 (1989) 1002-1008, https://doi. org/10.1126/science.246.4933.1002.

[6] R. German, History of sintering: empirical phase, Powder Metall. 56 (2013) 117-123, https://doi.org/10.1179/1743290112Y.0000000025.

[7] J.B. Ferguson, Note on the sintering of magnesia, J. Am. Ceram. Soc. 1 (1918) 439-440, https://doi.org/10.1111/j.1151-2916.1918.tb18608.x.

[8] R.K. Bordia, S.J.L. Kang, E.A. Olevsky, Current understanding and future research directions at the onset of the next century of sintering science and technology, J. Am. Ceram. Soc. 100 (2017) 2314-2352, https://doi.org/10.1111/jace.14919.

[9] F. Rhines, Seminar on the theory of sintering, Trans. AIME 166 (1946) 474.

[10] F. Lenel, Sintering in the presence of a liquid phase, Trans. AIME 175 (1948) 878-905.

[11] J. Frenkel, Viscous flow of crystalline bodies under the action of surface tension, J. phys. 9 (1945) 385.

[12] G.C. Kuczynski, Self-Diffusion in sintering of metallic particles, Met. Trans. 1 (1949) 169-178, https://doi.org/10.1007/978-94-009-0741-6_33.

[13] W.D. Kingery, M. Berg, Study of the initial stages of sintering solids by viscous flow, evaporation-condensation, and self-diffusion, J. Appl. Phys. 26 (1955) 1205-1212, https://doi.org/10.1063/1.1721874.

[14] R. Coble, Initial sintering of alumina and hematite, J. Am. Ceram. Soc. 41 (1958) 55-62, https://doi.org/10.1111/j.1151-2916.1958.tb13519.x.

[15] R.L. Coble, Sintering crystalline solids. I. Intermediate and final state diffusion models, J. Appl. Phys. 32 (1961) 787-792, https://doi.org/10.1063/1.1736107.

[16] R.L. Coble, Sintering crystalline solids. II. Experimental test of diffusion models in powder compacts, J. Appl. Phys. 32 (1961) 793-799, https://doi.org/10.1063/1. 1736108.

[17] M.N. Rahaman, Ceramic Processing and Sintering, CRC Press, 2003.

[18] R.M. German, P. Suri, S.J. Park, Liquid phase sintering, J. Mater. Sci. 44 (2009) 1-39, https://doi.org/10.1007/s10853-008-3008-0.

[19] S.-J.L. Kang, Sintering: Densification, Grain Growth and Microstructure, Elsevier, Amsterdam, 2004.

[20] W. Zhang, I. Gladwell, Performance of Mol for Surface Motion Driven by a Laplacian of Curvature, Springer Berlin Heidelberg, Berlin, Heidelberg, 2000, pp. 419-429.

[21] R. German, Sintering: From Empirical Observations to Scientific Principles, Butterworth-Heinemann, 2014.

[22] S. Somiya, Handbook of Advanced Ceramics: Materials, Applications, Processing, and Properties, Academic Press, 2013.

[23] S. Hampshire, Silicon nitride ceramics-review of structure, processing and properties, J. Achiev. Mater. Manuf. Eng. 24 (2007) 43-50.

[24] W. Kingery, Densification during sintering in the presence of a liquid phase, I. Theory, J. Appl. Phys. 30 (1959) 301-306, https://doi.org/10.1063/1.1735155.

[25] W. Kingery, M. Narasimhan, Densification during sintering in the presence of a liquid phase. II. Experimental, J. Appl. Phys. 30 (1959) 307-310, https://doi.org/ 10.1063/1.1735156.

[26] W.A. Kaysser, G. Petzow, Liquid phase sintering of ceramics, in: R.F. Davis, H. Palmour, R.L. Porter (Eds.), Emergent Process Methods for High-Technology Ceramics, Springer US, Boston, MA, 1984, pp. 225-231.

[27] W.D. Kingery, H.K. Bowen, D.R. Uhlmann, Introduction to Ceramics, Wiley, New York, 1976.

[28] P.C. Panda, W.M. Mobley, R. Raj, Effect of the heating rate on the relative rates of sintering and crystallization in glass, J. Am. Ceram. Soc. 72 (1989) 2361-2364, https://doi.org/10.1111/j.1151-2916.1989.tb06090.x.

[29] M. Biesuz, V.M. Sglavo, Flash sintering of ceramics, J. Eur. Ceram. Soc. 39 (2019) 115-143, https://doi.org/10.1016/j.jeurceramsoc.2018.08.048.

[30] B. Dzepina, D. Balint, D. Dini, A phase field model of pressure-assisted sintering, J. Eur. Ceram. Soc. 39 (2019) 173-182, https://doi.org/10.1016/j.jeurceramsoc. 2018.09.014

[31] R. Coble, Mechanisms of densification during hot pressing, in: G.C. Kuczynski, N.A. Hooton, C.F. Gibbon (Eds.), Sintering and Related Phenomena, Gordon and Breach, New York, 1967, pp. 329-350.

[32] R.L. Coble, Diffusion models for hot pressing with surface energy and pressure effects as driving forces, J. Appl. Phys. 41 (1970) 4798-4807, https://doi.org/10. $1063 / 1.1658543$

[33] R. Coble, A model for boundary diffusion controlled creep in polycrystalline materials, J. Appl. Phys. 34 (1963) 1679-1682, https://doi.org/10.1063/1.1702656.

[34] G. Pharr, M. Ashby, On creep enhanced by a liquid phase, Acta Metall. 31 (1983) 129-138, https://doi.org/10.1016/0001-6160(83)90072-X.
[35] F. Bouville, A.R. Studart, Geologically-inspired strong bulk ceramics made with water at room temperature, Nat. Commun. 8 (2017) 14655, https://doi.org/10. 1038/ncomms14655.

[36] J.-P. Gratier, D.K. Dysthe, F. Renard, The role of pressure solution creep in the ductility of the Earth's upper crust, Advances in Geophysics, Elsevier, 2013, pp. 47-179.

[37] C. Herring, Diffusional viscosity of a polycrystalline solid, J. Appl. Phys. 21 (1950) 437-445, https://doi.org/10.1063/1.1699681.

[38] D.S. Wilkinson, M. Ashby, Pressure sintering by power law creep, Acta Metall. 23 (1975) 1277-1285, https://doi.org/10.1016/0001-6160(75)90136-4.

[39] Z. Munir, U. Anselmi-Tamburini, M. Ohyanagi, The effect of electric field and pressure on the synthesis and consolidation of materials: a review of the spark plasma sintering method, J. Mater. Sci. 41 (2006) 763-777, https://doi.org/10 1007/s10853-006-6555-2.

[40] J. Garay, Current-activated, pressure-assisted densification of materials, Annu. Rev. Mater. Res. 40 (2010) 445-468, https://doi.org/10.1146/annurev-matsci070909-104433.

[41] E.A. Olevsky, E.V. Aleksandrova, A.M. Ilyina, D.V. Dudina, A.N. Novoselov, K.Y. Pelve, E.G. Grigoryev, Outside mainstream electronic databases: review of studies conducted in the USSR and post-soviet countries on electric current-assisted consolidation of powder materials, Materials 6 (2013) 4375-4440, https:// doi.org/10.3390/ma6104375.

[42] W.H. Sutton, Microwave processing of ceramics-an overview, Mater. Res. Soc. Symp. Proc. 269 (1992), https://doi.org/10.1557/PROC-269-3.

[43] J.D. Katz, Microwave sintering of ceramics, Annu. Rev. Mater. Sci. 22 (1992) 153-170, https://doi.org/10.1146/annurev.ms.22.080192.001101.

[44] M. Oghbaei, O. Mirzaee, Microwave versus conventional sintering: a review of fundamentals, advantages and applications, J. Alloys Compd. 494 (2010) 175-189, https://doi.org/10.1016/j.jallcom.2010.01.068.

[45] M. Yu, S. Grasso, R. Mckinnon, T. Saunders, M.J. Reece, Review of flash sintering materials, mechanisms and modelling, Adv. Appl. Ceram. 116 (2017) 24-60, https://doi.org/10.1080/17436753.2016.1251051.

[46] P. Bertrand, F. Bayle, C. Combe, P. Gœuriot, I. Smurov, Ceramic components manufacturing by selective laser sintering, Appl. Surf. Sci. 254 (2007) 989-992, https://doi.org/10.1016/j.apsusc.2007.08.085.

[47] D. Wilkinson, A pressure-sintering model for the densification of polar firn and glacier ice, J. Glaciol. 34 (1988) 40-45, https://doi.org/10.1017/ S0022143000009047.

[48] J.R. Blackford, Sintering and microstructure of ice: a review, J. Phys. D. 40 (2007) R355-R385, https://doi.org/10.1088/0022-3727/40/21/R02.

[49] W. Kingery, Regelation, surface diffusion, and ice sintering, J. Appl. Phys. 31 (1960) 833-838, https://doi.org/10.1063/1.1735704.

[50] J.G. Spray, Lithification mechanisms for planetary regoliths: The glue that binds, Annu. Rev. Earth Pl. Sc. 44 (2016) 139-174, https://doi.org/10.1146/annurevearth-060115-012203.

[51] D.M. Roy, G. Gouda, A. Bobrowsky, Very high strength cement pastes prepared by hot pressing and other high pressure techniques, Cem. Concr. Res. 2 (1972) 349-366, https://doi.org/10.1016/0008-8846(72)90075-0.

[52] D.M. Roy, G. Gouda, High strength generation in cement pastes, Cem. Concr. Res. 3 (1973) 807-820, https://doi.org/10.1016/0008-8846(73)90013-6.

[53] S. Sõmiya, Hydrothermal Reactions for Materials Science and Engineering: An Overview of Research in Japan, Springer Science \& Business Media, 2012.

[54] E. Gutmanas, A. Rabinkin, M. Roitberg, Cold sintering under high pressure, Scr. Mater. 13 (1979) 11-15, https://doi.org/10.1016/0036-9748(79)90380-6.

[55] E. Gutmanas, High-pressure compaction and cold sintering of stainless steel powders, Powder Metall. Int. 12 (1980) 178-183.

[56] N. Yamasaki, T. Weiping, Hydrothermal hot-pressing of calcium carbonate with sea water, J. Mater. Sci. Lett. 12 (1993) 516-519, https://doi.org/10.1007/ BF00452814.

[57] P. De Silva, L. Bucea, V. Sirivivatnanon, D.R. Moorehead, Carbonate binders by "cold sintering" of calcium carbonate, J. Mater. Sci. 42 (2007) 6792-6797, https://doi.org/10.1007/s10853-006-1428-2.

[58] H. Kähäri, M. Teirikangas, J. Juuti, H. Jantunen, Dielectric properties of lithium molybdate ceramic fabricated at room temperature, J. Am. Ceram. Soc. 97 (2014) 3378-3379, https://doi.org/10.1111/jace.13277.

[59] H. Takeda, S. Hashimoto, H. Matsui, S. Honda, Y. Iwamoto, Rapid fabrication of highly dense geopolymers using a warm press method and their ability to absorb neutron irradiation, Constr. Build. Mater. 50 (2014) 82-86, https://doi.org/10. 1016/j.conbuildmat.2013.09.014.

[60] H. Guo, A. Baker, J. Guo, C.A. Randall, Cold sintering process: a novel technique for low-temperature ceramic processing of ferroelectrics, J. Am. Ceram. Soc. 99 (2016) 3489-3507, https://doi.org/10.1111/jace.14554.

[61] C. Vakifahmetoglu, J.F. Anger, V. Atakan, S. Quinn, S. Gupta, Q. Li, L. Tang, R.E. Riman, Reactive hydrothermal liquid-phase densification (rHLPD) of ceramics-a study of the $\mathrm{BaTiO}_{3}\left[\mathrm{TiO}_{2}\right]$ composite system, J. Am. Ceram. Soc. 99 (2016) 3893-3901, https://doi.org/10.1111/jace.14468.

[62] S.I. Hirano, S. Somiya, Hydrothermal reaction sintering of pure $\mathrm{Cr}_{2} \mathrm{O}_{3}$, J. Am. Ceram. Soc. 59 (1976) 534, https://doi.org/10.1111/j.1151-2916.1976. tb09432.x.

[63] C. Curtis, L. Doney, J. Johnson, Some properties of hafnium oxide, hafnium silicate, calcium hafnate, and hafnium carbide, J. Am. Ceram. Soc. 37 (1954) 458-465, https://doi.org/10.1111/j.1151-2916.1954.tb13977.x.

[64] H. Toraya, M. Yoshimura, S. Somiya, Hydrothermal reaction-sintering of monoclinic $\mathrm{HfO}_{2}$, J. Am. Ceram. Soc. 65 (1982) c159-c160, https://doi.org/10.1111/j. 1151-2916.1982.tb10527.x.

[65] S.-I. Hirano, S. Somiya, Hydrothermal crystal growth of magnetite in the presence 
of hydrogen, J. Cryst. Growth 35 (1976) 273-278, https://doi.org/10.1016/00220248(76)90184-6.

[66] P. Ownby, G.E. Jungquist, Final sintering of $\mathrm{Cr}_{2} \mathrm{O}_{3}$, J. Am. Ceram. Soc. 55 (1972) 433-436, https://doi.org/10.1111/j.1151-2916.1972.tb11334.x.

[67] M. Yoshimura, S. Sōmiya, Fabrication of dense, nonstabilized $\mathrm{ZrO}_{2}$ ceramics by hydrothermal reaction sintering, Hydrothermal Reactions for Materials Science and Engineering, Springer, 1989, p. 15.

[68] M. Yoshimura, S. Sōmiya, Hydrothermal reaction sintering of monoclinic zirconia, Hydrothermal Reactions for Materials Science and Engineering, Springer, 1989, pp. 16-23.

[69] S. Sōmiya, Reactions for hydrothermal reaction sintering, Sintering Key Papers, Springer, 1990, pp. 679-685.

[70] K. Yanagisawa, Q. Feng, N. Yamasaki, Preparation of ceramics by hydrothermal hot-pressing, High Press. Res. 20 (2001) 343-349, https://doi.org/10.1080/ 08957950108206182.

[71] G. Goglio, A. Ndayishimiye, A. Largeteau, C. Elissalde, View point on hydrothermal sintering: main features, today's recent advances and tomorrow's promises, Scripta Mater. 158 (2019) 146-152, https://doi.org/10.1016/j.scriptamat. 2018.08.038.

[72] N. Yamasaki, K. Yanagisawa, M. Nishioka, S. Kanahara, A hydrothermal hotpressing method: apparatus and application, J. Mater. Sci. Lett. 5 (1986) 355-356, https://doi.org/10.1007/978-94-009-0743-0_70.

[73] Z. Matamoros-Veloza, J. Rendón-Angeles, K. Yanagisawa, E. Mejia-Martínez, J. Parga, Low temperature preparation of porous materials from TV panel glass compacted via hydrothermal hot pressing, Ceram. Int. 41 (2015) 12700-12709, https://doi.org/10.1016/j.ceramint.2015.06.102.

[74] N. Yamasaki, W. Tang, J. Ke, Low-temperature sintering of calcium carbonate by a hydrothermal hot-pressing technique, J. Mater. Sci. Lett. 11 (1992) 934-936, https://doi.org/10.1007/bf00729099.

[75] K. Yanagisawa, M. Sasaki, M. Nishioka, K. Ioku, N. Yamasaki, Preparation of sintered compacts of anatase by hydrothermal hot-pressing, J. Mater. Sci. Lett. 13 (1994) 765-766, https://doi.org/10.1007/bf00461398.

[76] A. Ndayishimiye, A. Largeteau, M. Prakasam, S. Pechev, M.-A. Dourges, G. Goglio, Low temperature hydrothermal sintering process for the quasi-complete densification of nanometric $\alpha$-quartz, Scripta Mater. 145 (2018) 118-121, https://doi. org/10.1016/j.scriptamat.2017.10.023.

[77] A. Ndayishimiye, A. Largeteau, S. Mornet, M. Duttine, M.-A. Dourges, D. Denux, M. Verdier, M. Gouné, T.H. de Beauvoir, C. Elissalde, Hydrothermal sintering for densification of silica. Evidence for the role of water, J. Eur. Ceram. Soc. 38 (2018) 1860-1870, https://doi.org/10.1016/j.jeurceramsoc.2017.10.011.

[78] A. Nakahira, H. Nishimoto, Y. Hamada, Y. Yamasaki, Synthesis and Characterization of Dense Mesoporous Alumina, Key Eng. Mater., Trans Tech Publ, 2014, pp. 252-257.

[79] H. Onoda, R. Sakai, A. Nakahira, I. Tanaka, Synthesis of porous aluminum phosphate bulks by hydrothermal hot pressing process and their analytical characterizations, Inorg. Mater. 45 (2009) 1048-1052, https://doi.org/10.1134/ s0020168509090180.

[80] T. Onoki, X. Wang, S. Zhu, Y. Hoshikawa, N. Sugiyama, M. Akao, E. Yasuda, M. Yoshimura, A. Inoue, Bioactivity of titanium-based bulk metallic glass surfaces via hydrothermal hot-pressing treatment, J. Ceram. Soc. Jpn. 116 (2008) 115-117, https://doi.org/10.2109/jcersj2.116.115.

[81] T. Onoki, X.M. Wang, S.L. Zhu, Y. Hoshikawa, N. Sugiyama, M. Akao, E. Yasuda, M. Yoshimura, A. Inoue, Apatite Forming Ability of Bulk Metallic Glass Surface via Hydrothermal Treatment, Key Eng. Mater., Trans Tech Publ, 2008, pp. 249-252.

[82] M. Li, H.-Y. Sun, X.-L. Liu, H.-Y. Xu, Y. Ren, D.-L. Cui, X. Tao, Preparation of porous boehmite nanosolid and its composite fluorescent materials by a novel hydrothermal hot-press method, Mater. Lett. 60 (2006) 2738-2742, https://doi. org/10.1016/j.matlet.2006.01.081.

[83] K. Sato, T. Hashida, H. Takahashi, N. Yamasaki, Development of high strength calcium aluminate-phosphate cement by hydrothermal hot-pressing, J. Mater. Sci. Lett. 16 (1997) 1464-1468, https://doi.org/10.1023/a:1018546318785.

[84] S. Katsuyama, M. Ito, Synthesis of $\mathrm{Ca}_{3} \mathrm{Co}_{4} \mathrm{O}_{9}$ ceramics by citric acid complex and hydrothermal hot-pressing processes and its thermoelectric properties, 25th International Conference on Thermoelectrics, 2006. ICT'06, IEEE, 2006, pp. 543-547.

[85] S. Katsuyama, Y. Takiguchi, M. Ito, Synthesis of $\mathrm{Ca}_{3} \mathrm{Co}_{4} \mathrm{O}_{9}$ ceramics by polymerized complex and hydrothermal hot-pressing processes and the investigation of its thermoelectric properties, J. Mater. Sci. 43 (2008) 3553-3559, https://doi. org /10.1007/s10853-008-2561-x.

[86] N. Yamasaki, T. Weiping, H. Lei, K. Hosoi, Solidification of aragonite-type $\mathrm{CaCO}_{3}$ powder containing chitosan with acetic acid by hydrothermal hot pressing, J. Mater. Sci. Lett. 14 (1995) 1751-1753, https://doi.org/10.1007/bf00270997.

[87] K. Hosoi, T. Hashida, H. Takahashi, N. Yamasaki, T. Korenaga, Low temperature solidification of calcium carbonate through vaterite-calcite wet transformation, J. Mater. Sci. Lett. 15 (1996) 812-814, https://doi.org/10.1007/bf00274614.

[88] K. Hosoi, T. Hashida, H. Takahashi, N. Yamasaki, T. Korenaga, Solidification behaviour of calcium carbonate via aragonite-calcite wet transformation with hydrothermal hot pressing, J. Mater. Sci. Lett. 16 (1997) 382-385, https://doi.org/ 10.1023/a:1018506714049.

[89] N. Yamasaki, L. Fei, S. Shimomto, Q. Chen, Fabrication of colored $\mathrm{CaCO}_{3}$ compacts by hydrothermal hot-pressing method, Mater. Res. Innovations 2 (1998) 45-48, https://doi.org/10.1007/s100190050060.

[90] N. Yamasaki, T. Weiping, K. Jiajun, K. Hosoi, Low-temperature sintering of calcium and magnesium carbonate by the hydrothermal hot-pressing technique, J. Mater. Sci. Lett. 14 (1995) 1268-1270, https://doi.org/10.1007/bf01262263.

[91] N. Yamasaki, T. Weiping, K. Yanagisawa, Solidification of $\mathrm{CaCO}_{3}$ containing $\mathrm{SrCO}_{3}$ by hydrothermal hot-pressing, J. Mater. Res. 8 (1993) 1972-1976, https://doi. org/10.1557/JMR.1993.1972.

[92] C. Udawatte, K. Yanagisawa, T. Kamakura, Y. Matsumoto, N. Yamasaki, Hardening of hydrothermal hot pressed calcium silicate compacts with rice husk as fiber reinforcement, Mater. Res. Innovations 3 (2000) 297-301, https://doi.org/10. 1007/s100190000048.

[93] T. Kamakura, Y. Matsumoto, T. Kuroki, N. Yamasaki, M. Uragami, G. Bignall, Development of continuous hydrothermal hot-pressing apparatus, High Press. Res. 20 (2001) 421-428, https://doi.org/10.1080/08957950108206190.

[94] H. Onoda, Y. Inagaki, A. Kuwabara, N. Kitamura, K. Amezawa, A. Nakahira, I. Tanaka, Synthesis and electrical conductivity of tetra-valent cerium polyphosphate bulks, Phosphorus Res. Bull. 23 (2009) 20-24, https://doi.org/10.3363/ prb.23.20.

[95] H. Onoda, Y. Inagaki, A. Kuwabara, N. Kitamura, K. Amezawa, A. Nakahira, I. Tanaka, Synthesis and electrical conductivity of bulk tetra-valent cerium pyr ophosphate, J. Ceram. Process Res. 11 (2010) 344-347.

[96] H. Onoda, K.-I. Okumoto, A. Nakahira, I. Tanaka, Mechanochemical effects on the synthesis of copper orthophosphate and cyclo-tetraphosphate bulks by the hydrothermal hot pressing method, Materials 2 (2009) 1-9, https://doi.org/10. 3390/ma2010001.

[97] H. Song, L. Wei, Y. Ji, L. Cao, F. Cheng, Heavy metal fixing and heat resistance abilities of coal fly ash-waste glass based geopolymers by hydrothermal hot pressing, Adv. Powder Technol. 29 (2018) 1487-1492, https://doi.org/10.1016/j. apt.2018.03.013.

[98] K. Hosoi, S. Kawai, K. Yanagisawa, N. Yamasaki, Densification process for spherical glass powders with the same particle size by hydrothermal hot pressing, J. Mater. Sci. 26 (1991) 6448-6452, https://doi.org/10.1007/bf00551895.

[99] T. Yoshikawa, S. Sato, T. Tanaka, Fabrication of low temperature foaming glass materials using hydrothermal treatment, ISIJ Int. 48 (2008) 130-133, https://doi org/10.2355/isijinternational.48.130.

[100] K. Ioku, T. Kai, M. Nishioka, K. Yanagisawa, N. Yamasaki, Bioactive glass-ceramics prepared by hydrothermal hot-pressing, J. Chem. Soc. Jpn. 1991 (1991) 1408-1412, https://doi.org/10.1246/nikkashi.1991.1408.

[101] N. Yamasaki, T. Kai, M. Nishioka, K. Yanagisawa, K. Ioku, Preparation of biologically active glass ceramics with rod-shaped crystals dispersion by hydrothermal hot-pressing, J. Mater. Sci. Lett. 11 (1992) 233-234, https://doi.org/10.1007/ bf00741430.

[102] M. Nishioka, K. Yanagisawa, N. Yamasaki, Solidification of glass powder by a hydrothermal hot-pressing technique, Hydrothermal Reactions for Materials Science and Engineering, Springer, 1989, pp. 417-422.

[103] K. Yanagisawa, M. Nishioka, N. Yamasaki, Densification process of borosilicate glass powders under hydrothermal hot-pressing conditions, J. Mater. Sci. 24 (1989) 4052-4056, https://doi.org/10.1007/bf01168973.

[104] Z.M. Veloza, K. Yanagizawa, N. Yamasaki, Recycling waste glasses by means of the hydrothermal hot pressing method, J. Mater. Sci. Lett. 18 (1999) 1811-1813, https://doi.org/10.1023/a:1006622616850.

[105] Z.M. Veloza, K. Yanagisawa, N. Yamasaki, Hydrothermal hot pressing for recycling of waste glass, High Press. Res. 20 (2001) 351-359, https://doi.org/10.1080/ 08957950108206183.

[106] N. Yamasaki, A. Shirakawa, N. Hirano, T. Hashida, Examination of solidified waste glass powder after hydrothermal hot pressing, J. Mater. Sci. Lett. 21 (2002) 711-713, https://doi.org/10.1023/A:1015785021932.

[107] Z. Matamoros-Veloza, K. Yanangisawa, J. Rendon-Angeles, S. Oishi, M. CisnerosGuerrero, Preparation of porous glass-ceramics under different hydrothermal hot pressing conditions, Solid State Ion. 172 (2004) 597-600, https://doi.org/10. 1016/j.ssi.2004.04.034.

[108] Z. Matamoros-Veloza, J. Rendón-Angeles, K. Yanagisawa, M. Cisneros-Guerrero, M. Cisneros-Guerrero, L. Aguirre, Preparation of foamed glasses from CRT TV glass by means of hydrothermal hot-pressing technique, J. Eur. Ceram. Soc. 28 (2008) 739-745, https://doi.org/10.1016/j.jeurceramsoc.2007.09.014.

[109] T. Yoshikawa, S. Sato, T. Tanaka, Fabrication of low temperature foaming glass materials using hydrothermal treatment, Mater. Sci. Forum 561-565 (2007) 1673-1675, https://doi.org/10.4028/www.scientific.net/MSF.561-565.1673.

[110] Z. Matamoros-Veloza, K. Yanagisawa, J. Rendon-Angeles, S. Oishi, The effect of hydrothermal hot-pressing parameters on the fabrication of porous ceramics using waste glass, J. Phys.: Condens. Matter 16 (S1361) (2004), https://doi.org/10. 1088/0953-8984/16/14/049.

[111] N. Yamasaki, T. Kai, M. Nishioka, K. Yanagisawa, K. Ioku, Porous hydroxyapatite ceramics prepared by hydrothermal hot-pressing, J. Mater. Sci. Lett. 9 (1990) 1150-1151, https://doi.org/10.1007/BF00721872.

[112] K. Ioku, K. Yamamoto, K. Yanagisawa, N. Yamasaki, Low temperature sintering of hydroxyapatite by hydrothermal hot-pressing, Phosphorus Res. Bull. 4 (1994) 65-70, https://doi.org/10.3363/prb1992.4.0_65.

[113] K. Hosoi, T. Hashida, H. Takahashi, N. Yamasaki, T. Korenaga, New processing technique for hydroxyapatite ceramics by the hydrothermal hot-pressing method, J. Am. Ceram. Soc. 79 (1996) 2771-2774, https://doi.org/10.1111/j.1151-2916. 1996.tb09048.x.

[114] K. Hosoi, T. Korenaga, T. Hashida, H. Takahashi, N. Yamasaki, New synthesis technique for making hydroxyapatite ceramics using hydrothermal hot-pressing, Rev. High Pres. Sci. Tech. 7 (1998) 1405-1407, https://doi.org/10.4131/ jshpreview.7.1405.

[115] K. Yanagisawa, T. Fujino, K. Zhu, K. Ioku, A. Onda, K. Kajiyoshi, C.-W. Chen, R.E. Riman, Development of low temperature sintering of hydroxyapatite ceramics using hydrothermal hot-pressing method, Phosphorus Res. Bull. 17 (2004) 231-234, https://doi.org/10.3363/prb1992.17.0_231.

[116] A. Nakahira, T. Murakami, T. Onoki, T. Hashida, K. Hosoi, Fabrication of porous 
hydroxyapatite using hydrothermal hot pressing and post-sintering, J. Am. Ceram. Soc. 88 (2005) 1334-1336, https://doi.org/10.1111/j.1551-2916.2005.00238.x.

[117] J.G. Li, T. Hashida, In situ formation of hydroxyapatite-whisker ceramics by hydrothermal hot-pressing method, J. Am. Ceram. Soc. 89 (2006) 3544-3546, https://doi.org/10.1111/j.1551-2916.2006.01149.x.

[118] H. Song, S.R. Kim, H.J. Kim, J.H. Hwang, W.T. Kwon, Y. Kim, Preparation and Characterization of Porous Hydroxyapatite Block Using a HHP Method, Key Eng. Mater., Trans Tech Publ, 2006, pp. 1067-1070.

[119] K. Yanagisawa, K. Zhu, T. Fujino, A. Onda, K. Kajiyoshi, K. Ioku, Preparation of Hydroxyapatite Ceramics by Hydrothermal Hot-pressing Technique, Key Eng. Mater., Trans Tech Publ, 2006, pp. 57-60.

[120] J. Li, T. Hashida, Preparation of hydroxyapatite ceramics by hydrothermal hotpressing method at 300 C, J. Mater. Sci. 42 (2007) 5013-5019, https://doi.org/10. 1007/s10853-006-0613-7.

[121] K. Yanagisawa, J.-H. Kim, C. Sakata, A. Onda, E. Sasabe, T. Yamamoto, Z. Matamoros-Veloza, J.C. Rendón-Angeles, Hydrothermal sintering under mild temperature conditions: preparation of calcium-deficient hydroxyapatite compacts, Z. Naturforsch., B: Chem. Sci. 65 (2010) 1038-1044, https://doi.org/10. 1515/znb-2010-0810.

[122] J.-H. Kim, K. Yanagisawa, A. Onda, E. Sasabe, T. Yamamoto, Densification behavior of hydroxyapatite green pellets prepared by different methods, J. Ceram. Soc. Jpn. 123 (2015) 1097-1101, https://doi.org/10.2109/jcersj2.123.1097.

[123] K. Montoya-Cisneros, J. Rendón-Angeles, Z. Matamoros-Veloza, A. MatamorosVeloza, K. Yanagisawa, Low-temperature densification of Mg-doped hydroxyapatite fine powders under hydrothermal hot processing conditions, Ceram. Int. 43 (2017) 11907-11919, https://doi.org/10.1016/j.ceramint.2017.06.039.

[124] E. Erydani Mejia-Martinez, Z. Matamoros-Veloza, K. Yanagisawa, J. Carlos Rendon-Angeles, B. Moreno-Perez, Influence of temperature on hydrothermal hotpressing of magnesium hydroxyapatite powder, Bol. Soc. Esp. Ceram. 57 (2018) 45-54, https://doi.org/10.1016/j.bsecv.2017.06.003.

[125] T. Onoki, A. Nakahira, T. Tago, Y. Hasegawa, T. Kuno, Novel low temperature processing techniques for apatite ceramics and chitosan polymer composite bulk materials and its mechanical properties, Appl. Surf. Sci. 262 (2012) 263-266, https://doi.org/10.1016/j.apsusc.2012.09.031.

[126] N. Yamasaki, K. Yanagisawa, N. Kakiuchi, Production of hydroxyapatite-glass compacts by hydrothermal hot-pressing technique, J. Mater. Res. 5 (1990) 647-653, https://doi.org/10.1557/JMR.1990.0647.

[127] Y. Kim, S.R. Kim, H. Song, H. Yoon, Preparation of Porous Hydroxyapatite/TCP Composite Block Using a Hydrothermal Hot Pressing Method, Mater. Sci. Forum, Trans Tech Publ, 2005, pp. 117-120.

[128] H. Song, S.R. Kim, J.H. Hwang, Y. Kim, Preparation of Porous Hydroxyapatite/ tricalcium Phosphate Composite Block Using a HHP Method, Key Eng. Mater. Trans Tech Publ, 2006, pp. 1071-1074.

[129] T. Onoki, S.-Y. Yamamoto, Hydroxyapatite ceramics coating on magnesium alloy via a double layered capsule hydrothermal hot-pressing, J. Ceram. Soc. Jpn. 118 (2010) 749-752, https://doi.org/10.2109/jcersj2.118.749.

[130] T. Onoki, S.y. Yamamoto, H. Onodera, A. Nakahira,, New technique for bonding hydroxyapatite ceramics and magnesium alloy by hydrothermal hot-pressing method, Mater. Sci. Eng,: C 31 (2) (2011) 499-502, https://doi.org/10.1016/j. msec.2010.09.002.

[131] T. Onoki, K. Hosoi, T. Hashida, Joining Hydroxyapatite Ceramics and Titanium Alloys by Hydrothermal Method, Key Eng. Mater., Trans Tech Publ, 2003, pp. 571-574.

[132] T. Onoki, K. Hosoi, T. Hashida, New technique for bonding hydroxyapatite ceramics and titanium by the hydrothermal hot-pressing method, Scripta Mater. 52 (2005) 767-770, https://doi.org/10.1016/j.scriptamat.2004.12.011.

[133] T. Onoki, T. Hashida, New method for hydroxyapatite coating of titanium by the hydrothermal hot isostatic pressing technique, Surf. Coat. Technol. 200 (2006) 6801-6807, https://doi.org/10.1016/j.surfcoat.2005.10.016.

[134] T. Onoki, T. Hashida, Novel Method for Hydroxyapatite Coating by Hydrothermal Hot-pressing via Double Layered Capsule, Key Eng. Mater., Trans Tech Publ, 2006, pp. 647-650.

[135] T. Onoki, K. Hosoi, T. Hashida, Effects of water location in starting materials on bonding behavior of hydroxyapatite and titanium via hydrothermal hot-pressing, AIP Conference Proceedings, AIP (2006) 112-115.

[136] M.A. Tanaka, T. Onoki, K. Hosoi, T. Hashida, Effects of pressure and reaction time on bonding of hydroxyapatite ceramics and titanium by hydrothermal hot-pressing, AIP Conference Proceedings, AIP, 2006, pp. 82-84.

[137] T. Onoki, K. Hosoi, T. Hashida, Y. Tanabe, T. Watanabe, E. Yasuda, M. Yoshimura, Effects of titanium surface modifications on bonding behavior of hydroxyapatite ceramics and titanium by hydrothermal hot-pressing, Mater. Sci. Eng., C 28 (2008) 207-212, https://doi.org/10.1016/j.msec.2006.12.002.

[138] T. Onoki, T. Higashi, X. Wang, S. Zhu, N. Sugiyama, Y. Hoshikawa, M. Akao, N. Matsushita, A. Nakahira, E. Yasuda, Interface structure between Ti-based bulk metallic glasses and hydroxyapatite ceramics jointed by hydrothermal techniques, Mater. Trans. 50 (2009) 1308-1312, https://doi.org/10.2320/matertrans. ME200815.

[139] T. Onoki, X. Wang, S. Zhu, N. Sugiyama, Y. Hoshikawa, M. Akao, N. Matsushita, A. Nakahira, E. Yasuda, M. Yoshimura, Effects of growing integrated layer [GIL] formation on bonding behavior between hydroxyapatite ceramics and Ti-based bulk metallic glasses via hydrothermal hot-pressing, Mater. Sci. Eng., B 161 (2009) 27-30, https://doi.org/10.1016/j.mseb.2008.11.011.

[140] H. Onoda, A. Yoshida, Synthesis and properties of bulk lanthanum phosphates obtained by hydrothermal hot pressing, J. Ceram. Process Res. 13 (2012) 622-626.

[141] H. Onoda, T. Yamasaki, Synthesis of bulk lanthanum polyphosphate and other rare earth phosphates through hydrothermal hot-pressing, J. Adv. Ceram. 2 (2013) 301-307, https://doi.org/10.1007/s40145-013-0074-9.

[142] A. Ndayishimiye, S. Buffière, M.-A. Dourges, A. Largeteau, M. Prakasam, S. Mornet, O. Kaman, J. Zdeněk, J. Hejtmánek, G. Goglio, Design of 0-3 type nanocomposites using hydrothermal sintering, Scripta Mater. 148 (2018) 15-19, https://doi.org/10.1016/j.scriptamat.2018.01.013.

[143] O. Kaman, Z. Jirák, J. Hejtmánek, A. Ndayishimiye, M. Prakasam, G. Goglio, Tunneling magnetoresistance of hydrothermally sintered $\mathrm{La}_{1-\mathrm{x}} \mathrm{Sr}_{\mathrm{x}} \mathrm{MnO}_{3}$-silica nanocomposites, J. Magn. Magn. Mater. 479 (2019) 135-143, https://doi.org/10. 1016/j.jmmm.2019.01.114.

[144] S. Katsuyama, A. Kishida, M. Ito, Synthesis of $\mathrm{Na}_{\mathrm{x}} \mathrm{Co}_{2} \mathrm{O}_{4}$ by the hydrothermal hotpressing and its thermoelectric properties, J. Alloys Compd. 414 (2006) 215-220, https://doi.org/10.1016/j.jallcom.2005.05.050.

[145] S. Ishihara, T. Matsumoto, T. Onoki, T. Sohmura, A. Nakahira, New concept bioceramics composed of octacalcium phosphate (OCP) and dicarboxylic acid-intercalated OCP via hydrothermal hot-pressing, Mater. Sci. Eng.: C 29 (6) (2009) 1885-1888, https://doi.org/10.1016/j.msec.2009.02.023.

[146] K. Satoh, T. Hashida, H. Takahashi, N. Yamasaki, Solidification method for phosphate bonded alumina cement by hydrothermal hot-pressing, J. Ceram. Soc. Jpn. 105 (1997) 424-427, https://doi.org/10.2109/jcersj.105.424.

[147] K. Yanagisawa, M. Nishioka, K. Ioku, N. Yamasaki, Neck formation of spherical silica particles by hydrothermal hot pressing, J. Mater. Sci. Lett. 10 (1991) 7-8, https://doi.org/10.1007/bf00724415.

[148] K. Yanagisawa, M. Nishioka, K. Ioku, N. Yamasaki, Low temperature sintering of spherical silica powder by hydrothermal hot-pressing, J. Ceram. Soc. Jpn. 99 (1991) 59-62, https://doi.org/10.2109/jcersj.99.59.

[149] K. Yanagisawa, M. Nishioka, K. Ioku, N. Yamasaki, Densification of silica gels by hydrothermal hot-pressing, J. Mater. Sci. Lett. 12 (1993) 1073-1075, https://doi. org/10.1007/BF00420525.

[150] K. Yanagisawa, K. Ioku, N. Yamasaki, Pore size control of porous silica ceramics by hydrothermal hot-pressing, J. Ceram. Soc. Jpn. 102 (1994) 966-971, https://doi. org/10.2109/jcersj.102.966.

[151] H. Nagata, M. Takimura, Y. Yamasaki, A. Nakahira, Syntheses and characterization of bulky mesoporous silica MCM-41 by hydrothermal hot-pressing method, Mater. Trans. 47 (2006) 2103-2105, https://doi.org/10.2320/matertrans.47. 2103.

[152] M. Takimura, H. Nagata, Y. Yamasaki, T. Suzuki, Y. Ikuhara, A. Nakahira, Synthesis and characterization of bulky FSM with interconnected mesopore-networks using an HHP method, J. Ceram. Soc. Jpn. 114 (2006) 554-557, https:// doi.org/10.2109/jcersj.114.554.

[153] A. Nakahira, M. Takimura, Y. Yamasaki, Synthesis of bulky mesoporous silica (FSM) by hydrothermal hot-pressing method, J. Non-Cryst. Solids 353 (2007) 4203-4207, https://doi.org/10.1016/j.jnoncrysol.2007.07.017.

[154] M. Takimura, H. Nagata, Y. Yamasaki, A. Nakahira, Synthesis of Dense Mesoporous Silica with High Surface Area by Hydrothermal Hot-pressing (HHP) Method, Solid State Phenomena, Trans Tech Publ, 2007, pp. 1833-1836.

[155] A. Nakahira, H. Nagata, T. Onoki, Y. Yamasaki, Evaluation of microstructures and properties of bulk mesoporous silica, Res. Chem. Intermed. 34 (2008) 347-352, https://doi.org/10.1163/156856708784040696.

[156] A. Nakahira, T. Hamada, Y. Yamauchi, Synthesis and properties of dense bulks for mesoporous silica SBA-15 by a modified hydrothermal method, Mater. Lett. 64 (2010) 2053-2055, https://doi.org/10.1016/j.matlet.2010.06.035.

[157] N. Suzuki, Y.-T. Huang, Y. Nemoto, A. Nakahira, Y. Yamauchi, Highly densified mesoporous bulk silica prepared with colloidal mesoporous silica nanoparticles toward a new low-k material, Chem. Lett. 41 (2012) 1518-1519, https://doi.org/ 10.1246/cl.2012.1518.

[158] Y. Xie, S. Yin, H. Yamane, T. Hashimoto, T. Sato, Low temperature sintering and color of a new compound $\mathrm{Sn}_{1.24} \mathrm{Ti}_{1.94} \mathrm{O}_{3.66}(\mathrm{OH})_{1.50} \mathrm{~F}_{1.42}$, Solid State Sciences 11 (9) (2009) 1703-1708, https://doi.org/10.1016/j.solidstatesciences.2009.05.025.

[159] K. Yanagisawa, K. Ioku, N. Yamasaki, Crystallization of amorphous hydrous titania under hydrothermal hot-pressing conditions, J. Ceram. Soc. Jpn. 102 (1994) 1091-1093, https://doi.org/10.2109/jcersj.102.1091.

[160] K. Yanagisawa, K. Ioku, N. Yamasaki, Post-sintering of anatase compact prepared by hydrothermal hot-pressing, J. Mater. Sci. Lett. 14 (1995) 161-163, https://doi. org/10.1007/BF00318242.

[161] K. Yanagisawa, K. Ioku, N. Yamasaki, Formation of anatase porous ceramics by hydrothermal hot-pressing of amorphous titania spheres, J. Am. Ceram. Soc. 80 (1997) 1303-1306, https://doi.org/10.1111/j.1151-2916.1997.tb02982.x.

[162] T. Kubo, A. Nakahira, Y. Yamasaki, Fabrication of mesoporous bulk composed of titanate nanotubes by hydrothermal hot-pressing technique, J. Mater. Res. 22 (2007) 1286-1291, https://doi.org/10.1557/jmr.2007.0160.

[163] T. Kubo, M. Takeuchi, M. Matsuoka, M. Anpo, A. Nakahira, Morphologic control of Pt supported titanate nanotubes and their photocatalytic property, Catal. Lett. 130 (2009) 28-36, https://doi.org/10.1007/s10562-009-9851-z.

[164] A. Nakahira, T. Kubo, Y. Yamasaki, Microstructural control of mesoporous bulk composed of $\mathrm{TiO}_{2}$-derived titanate nanotubes, ACS Appl. Mater. Interfaces. 2 (2010) 1136-1140, https://doi.org/10.1021/am900931v.

[165] C. Udawatte, K. Yanagisawa, T. Kamakura, Y. Matsumoto, N. Yamasaki, Solidification of xonotlite fibers with chitosan by hydrothermal hot pressing, Mater. Lett. 45 (2000) 298-301, https://doi.org/10.1016/S0167-577X(00) 00121-X.

[166] A. Nakahira, S. Takezoe, Y. Yamasaki, Synthesis of dense Y-zeolite bulks with large surface area using a hydrothermal hot-pressing (HHP) process, Chem. Lett. 33 (2004) 1400-1401, https://doi.org/10.1246/cl.2004.1400.

[167] S. Takezoe, K. Hosoi, M. Tajika, Y. Yamasaki, A. Nakahira, Syntheses of Bulky Y. zeolite by Hydrothermal Hot-pressing (HHP) Technique, Key Eng. Mater., Trans 
Tech Publ, 2006, pp. 97-100.

[168] A. Nakahira, S. Takezoe, Y. Yamasaki, Y. Sasaki, Y. Ikuhara, Synthesis and evaluation of bulky Y-Zeolites by hydrothermal hot-pressing method, J. Am. Ceram. Soc. 90 (2007) 2322-2326, https://doi.org/10.1111/j.1551-2916.2007.01721.x.

[169] T. Onoki, Zeolite Y deposition on aluminum substrate without structure directing agents (SDAs), Mater. Lett. 71 (2012) 25-27, https://doi.org/10.1016/j.matlet. 2011.11.095.

[170] F.-S. Xiao, G. Pang, T. Ji, X. Meng, W. Pang, R. Xu, Catalytic cracking activity and physicochemical properties of rey zeolite mixed with kaolin clay treated by hydrothermal hot pressing method, Appl. Catal., A 133 (1995) 305-320, https://doi. org/10.1016/0926-860X(95)00176-X.

[171] H. Nishizawa, H. Tebika, N. Yamasaki, Fabrication of stabilized zirconia compressed body under hydrothermal conditions and its sintering, J. Ceram. Soc. Jpn. 92 (1984) 420

[172] T. Yoshikawa, M. Hosokawa, T. Tanaka, MgO effect on hydrothermal solidification of blast furnace slag, ISIJ Int. 48 (2008) 557-562, https://doi.org/10.2355/ isijinternational.48.557.

[173] S.-J. Tae, T. Tanaka, K. Morita, Effect of microwave irradiation on hydrothermal treatment of blast furnace slag, ISIJ Int. 49 (2009) 1259-1264, https://doi.org/10. 2355/isijinternational.49.1259.

[174] Y. Nakane, K. Sato, H. Takahashi, N. Yamasaki, T. Hashida, Development of solidification technique for recycle of concrete wastes by hydrothermal hot-pressing and its mechanical property, J. Ceram. Soc. Jpn. 102 (1994) 405-407, https://doi. org/10.2109/jcersj.102.405.

[175] K. Sato, T. Hashida, H. Takahashi, N. Yamasaki, Strengthening of hydrothermal hot-pressed concrete waste by the addition of slag, J. Ceram. Soc. Jpn. 105 (1997) 262-264, https://doi.org/10.2109/jcersj.105.262.

[176] Y. Nakane, T. Hashida, H. Takahashi, N. Yamasaki, Strengthening of hydrothermal hot-pressed concrete wastes by the addition of fresh cement, J. Ceram. Soc. Jpn. 103 (1995) 511-514, https://doi.org/10.2109/jcersj.103.511.

[177] P. Sun, H.-C. Wu, Transition from brittle to ductile behavior of fly ash using PVA fibers, Cem. Concr. Compos. 30 (2008) 29-36, https://doi.org/10.1016/j. cemconcomp.2007.05.008.

[178] P. Sun, H.-C. Wu, Splitting tensile strength of fly ash activated by hydrothermal hot-pressing process, J. Mater. Civ. Eng. 21 (2009) 356-361, https://doi.org/10 1061/(ASCE)0899-1561(2009) 21:8(356).

[179] F. Xue, H. Song, Y. Ji, L. Cao, F. Cheng, Hydrothermal hot-pressing solidification of coal fly ash and its ability of fixing heavy metal, J. Residuals Sci. Tech. 12 (2015), https://doi.org/10.12783/issn.1544-8053/12/3/4.

[180] M. Nishioka, S. Hirai, K. Yanagisawa, N. Yamasaki, Solidification of glass powder with simulated high-level radioactive waste during hydrothermal hot-pressing, J. Am. Ceram. Soc. 73 (1990) 317-322, https://doi.org/10.1111/j.1151-2916.1990. tb06512.x.

[181] K. Yanagisawa, M. Nishioka, N. Yamasaki, Immobilization of cesium into pollucite structure by hydrothermal hot-pressing, J. Nucl. Sci. Technol. 24 (1987) 51-60, https://doi.org/10.3327/jnst.24.51.

[182] N. Yamasaki, M. Nishioka, K. Yanagisawa, Immobilization of simulated hlw by hydrothermal hot-pressing of glass powder, J. At. Energy Soc. Jpn. 30 (1988) 815-820.

[183] N. Yamasaki, K. Yanagisawa, K. Kinoshita, T. Kashiwai, Solidification of waste containing sodium borate by hydrothermal hot-pressing, J. At. Energy Soc. Jpn. 30 (1988) 714-724, https://doi.org/10.3327/jaesj.30.714.

[184] K. Yanagisawa, M. Nishioka, N. Yamasaki, Immobilization of low-level radioactive waste containing sodium sulfate by hydro-thermal hot-pressing, J. Nucl. Sci. Technol. 26 (1989) 395-397, https://doi.org/10.1080/18811248.1989.9734322.

[185] K. Yanagisawa, N. Yamasaki, N. Kozai, S. Muraoka, Leachability of waste form containing cesium produced by hydrothermal hot-pressing, J. Nucl. Sci. Technol. 27 (1990) 1072-1074, https://doi.org/10.1080/18811248.1990.9731294.

[186] M. Nishioka, K. Yanagisawa, N. Yamasaki, Solidification of sludge ash by hydrothermal hot-pressing, J. Water Pollut. Control Fed. (1990) 926-932.

[187] K. Yanagisawa, Z. Matamoros-Veloza, J. Rendon-Angeles, J. López-Cuevas, Novel route for recycling of steelmaking slag by means of the hydrothermal hot-pressing method, J. Mater. Sci. Lett. 21 (2002) 693-695, https://doi.org/10.1023/ A:1015724803277.

[188] O. Khelifi, Y. Kozuki, H. Murakami, K. Kurata, M. Nishioka, Nutrients adsorption from seawater by new porous carrier made from zeolitized fly ash and slag, Mar. Pollut. Bull. 45 (2002) 311-315, https://doi.org/10.1016/S0025-326X(02) 00107-8.

[189] T. Onoki, T. Kuno, A. Nakahira, T. Hashida, Effects of titanium surface treatment on adhesive properties of hydroxyapatite ceramics coating to titanium substrates by double layered capsule hydrothermal hot-pressing, J. Ceram. Soc. Jpn. 118 (2010) 530-534, https://doi.org/10.2109/jcersj2.118.530.

[190] M. Gallas, A. Rosa, T. Costa, J. Da Jornada, High pressure compaction of nanosize ceramic powders, J. Mater. Res. 12 (1997) 764-768, https://doi.org/10.1557/ JMR.1997.0111.

[191] T. Costa, M. Gallas, E. Benvenutti, J. Da Jornada, Infrared and thermogravimetric study of high pressure consolidation in alkoxide silica gel powders, J. Non-Cryst. Solids 220 (1997) 195-201, https://doi.org/10.1016/S0022-3093(97)00236-6.

[192] J.B. Brito, T.M.H. Costa, F.S. Rodembusch, N.M. Balzaretti, Photoluminescence of silica monoliths prepared from cold sintering of nanometric aerosil precursors under high pressure, J. Lumin. 187 (2017) 154-159, https://doi.org/10.1016/j. jlumin.2017.03.013.

[193] H. Kähäri, M. Teirikangas, J. Juuti, H. Jantunen, Improvements and modifications to room-temperature fabrication method for dielectric $\mathrm{Li}_{2} \mathrm{MoO}_{4}$ ceramics, J. Am. Ceram. Soc. 98 (2015) 687-689, https://doi.org/10.1111/jace.13471.

[194] M. Väätäjä, H. Kähäri, J. Juuti, H. Jantunen, $\mathrm{Li}_{2} \mathrm{MoO}_{4}$-based composite ceramics fabricated from temperature-and atmosphere-sensitive MnZn ferrite at room temperature, J. Am. Ceram. Soc. 100 (2017) 3626-3635, https://doi.org/10. 1111/jace.14914.

[195] H. Kähäri, M. Teirikangas, J. Juuti, H. Jantunen, Room-temperature fabrication of microwave dielectric $\mathrm{Li}_{2} \mathrm{MoO}_{4}-\mathrm{TiO}_{2}$ composite ceramics, Ceram. Int. 42 (2016) 11442-11446, https://doi.org/10.1016/j.ceramint.2016.04.081.

[196] H. Kähäri, P. Ramachandran, J. Juuti, H. Jantunen, Room-temperature-densified $\mathrm{Li}_{2} \mathrm{MoO}_{4}$ ceramic patch antenna and the effect of humidity, Int. J. Appl. Ceram. Tec. 14 (2017) 50-55, https://doi.org/10.1111/ijac.12615.

[197] P. Ramachandran, H. Kähäri, J. Juuti, H. Jantunen, Room temperature densified ceramics for weight optimized circular polarized gps antenna design, Microw. Opt. Techn. Let. 60 (2018) 1061-1066, https://doi.org/10.1002/mop.31105.

[198] A. Jiang, D. Ke, L. Xu, Q. Xu, J. Li, J. Wei, C. Hu, S. Grasso, Cold hydrostatic sintering: from shaping to 3D printing, J. Materiomics (2019), https://doi.org/10. 1016/j.jmat.2019.02.009.

[199] M. Nelo, J. Peräntie, T. Siponkoski, J. Juuti, H. Jantunen, Upside-down composites: electroceramics without sintering, Appl. Mater. Today 15 (2019) 83-86, https://doi.org/10.1016/j.apmt.2018.12.021.

[200] M. Nelo, T. Siponkoski, H. Kähäri, K. Kordas, J. Juuti, H. Jantunen, Upside-down composites: fabricating piezoceramics at room temperature, J. Eur. Ceram. Soc. 39 (2019) 3301-3306, https://doi.org/10.1016/j.jeurceramsoc.2019.04.052.

[201] J.-P. Maria, X. Kang, R.D. Floyd, E.C. Dickey, H. Guo, J. Guo, A. Baker, S. Funihashi, C.A. Randall, Cold sintering: current status and prospects, J. Mater Res. 32 (2017) 3205-3218, https://doi.org/10.1557/jmr.2017.262.

[202] W.B. Hong, L. Li, M. Cao, X.M. Chen, Plastic deformation and effects of water in room-temperature cold sintering of $\mathrm{NaCl}$ microwave dielectric ceramics, J. Am. Ceram. Soc. 101 (2018) 4038-4043, https://doi.org/10.1111/jace.15572.

[203] H. Guo, J. Guo, A. Baker, C.A. Randall, Hydrothermal-assisted cold sintering process: a new guidance for low-temperature ceramic sintering, ACS Appl. Mater. Interfaces 8 (2016) 20909-20915, https://doi.org/10.1021/acsami.6b07481.

[204] J. Guo, H. Guo, A.L. Baker, M.T. Lanagan, E.R. Kupp, G.L. Messing, C.A. Randall, Cold sintering: a paradigm shift for processing and integration of ceramics, Angew. Chem. Int. Ed. 55 (2016) 11457-11461, https://doi.org/10.1002/anie. 201605443.

[205] S. Funahashi, J. Guo, H. Guo, K. Wang, A.L. Baker, K. Shiratsuyu, C.A. Randall, Demonstration of the cold sintering process study for the densification and grain growth of ZnO ceramics, J. Am. Ceram. Soc. 100 (2017) 546-553, https://doi.org/ 10.1111/jace.14617.

[206] E. Shotton, J. Rees, The compaction properties of sodium chloride in the presence of moisture, J. Pharm. Pharmacol. 18 (1966) 160S-167S, https://doi.org/10. 1111/j.2042-7158.1966.tb07979.x.

[207] X. Kang, R. Floyd, S. Lowum, D. Long, E. Dickey, J.-P. Maria, Cold sintering with dimethyl sulfoxide solutions for metal oxides, J. Mater. Sci. 54 (2019) 7438-7446, https://doi.org/10.1007/s10853-019-03410-1.

[208] H. Guo, A. Baker, J. Guo, C.A. Randall, Protocol for ultralow-temperature ceramic sintering: an integration of nanotechnology and the cold sintering process, ACS Nano 10 (2016) 10606-10614, https://doi.org/10.1021/acsnano.6b03800.

[209] H. Guo, J. Guo, A. Baker, C.A. Randall, Cold sintering process for $\mathrm{ZrO}_{2}$-based ceramics: significantly enhanced densification evolution in yttria-doped $\mathrm{ZrO}_{2}$, J. Am. Ceram. Soc. 100 (2017) 491-495, https://doi.org/10.1111/jace.14593.

[210] H. Guo, T.J. Bayer, J. Guo, A. Baker, C.A. Randall, Current progress and perspectives of applying cold sintering process to $\mathrm{ZrO}_{2}$-based ceramics, Scripta Mater. 136 (2017) 141-148, https://doi.org/10.1016/j.scriptamat.2017.02.004.

[211] H. Guo, T.J. Bayer, J. Guo, A. Baker, C.A. Randall, Cold sintering process for $8 \mathrm{mo}$ $\% \mathrm{Y}_{2} \mathrm{O}_{3}$-stabilized $\mathrm{ZrO}_{2}$ ceramics, J. Eur. Ceram. Soc. 37 (2017) 2303-2308, https://doi.org/10.1016/j.jeurceramsoc.2017.01.011.

[212] D.S.B. Heidary, M. Lanagan, C.A. Randall, Contrasting energy efficiency in various ceramic sintering processes, J. Eur. Ceram. Soc. 38 (2018) 1018-1029, https:// doi.org/10.1016/j.jeurceramsoc.2017.10.015.

[213] J.-P. Ma, X.-M. Chen, W.-Q. Ouyang, J. Wang, H. Li, J.-L. Fang, Microstructure, dielectric, and energy storage properties of $\mathrm{BaTiO}_{3}$ ceramics prepared via cold sintering, Ceram. Int. 44 (2018) 4436-4441, https://doi.org/10.1016/j.ceramint. 2017.12.044.

[214] D. Wang, H. Guo, C.S. Morandi, C.A. Randall, S. Trolier-McKinstry, Cold sintering and electrical characterization of lead zirconate titanate piezoelectric ceramics, APL Mater. 6 (2018) 016101, https://doi.org/10.1063/1.5004420.

[215] R. Boston, J. Guo, S. Funahashi, A. Baker, I. Reaney, C. Randall, Reactive intermediate phase cold sintering in strontium titanate, RSC Adv. 8 (2018) 20372-20378, https://doi.org/10.1039/C8RA03072C.

[216] A. Baker, H. Guo, J. Guo, C. Randall, Utilizing the cold sintering process for flexible-printable electroceramic device fabrication, J. Am. Ceram. Soc. 99 (2016) 3202-3204, https://doi.org/10.1111/jace.14467.

[217] S.S. Berbano, J. Guo, H. Guo, M.T. Lanagan, C.A. Randall, Cold sintering process of $\mathrm{Li}_{1.5} \mathrm{Al}_{0.5} \mathrm{Ge}_{1.5}\left(\mathrm{PO}_{4}\right)_{3}$ solid electrolyte, J. Am. Ceram. Soc. 100 (5) (2017) 2123-2135, https://doi.org/10.1111/jace:2017.100.issue-510.1111/jace:14727.

[218] S. Funahashi, H. Guo, J. Guo, A.L. Baker, K. Wang, K. Shiratsuyu, C.A. Randall, Cold sintering and co-firing of a multilayer device with thermoelectric materials, J. Am. Ceram. Soc. 100 (2017) 3488-3496, https://doi.org/10.1111/jace.14852.

[219] J.-H. Seo, J. Guo, H. Guo, K. Verlinde, D.S.B. Heidary, R. Rajagopalan, C.A. Randall, Cold sintering of a Li-ion cathode: $\mathrm{LiFePO}_{4}$-composite with high volumetric capacity, Ceram. Int. 43 (2017) 15370-15374, https://doi.org/10. 1016/j.ceramint.2017.08.077.

[220] J.-H. Seo, K. Verlinde, J. Guo, D.S.B. Heidary, R. Rajagopalan, T.E. Mallouk, C.A. Randall, Cold sintering approach to fabrication of high rate performance binderless $\mathrm{LiFePO}_{4}$ cathode with high volumetric capacity, Scripta Mater. 146 (2018) 267-271, https://doi.org/10.1016/j.scriptamat.2017.12.005. 
[221] Y. Liu, Q. Sun, D. Wang, K. Adair, J. Liang, X. Sun, Development of the cold sintering process and its application in solid-state lithium batteries, J. Power Sources 393 (2018) 193-203, https://doi.org/10.1016/j.jpowsour.2018.05.015.

[222] I. Induja, M. Sebastian, Microwave dielectric properties of cold sintered $\mathrm{Al}_{2} \mathrm{O}_{3}$ $\mathrm{NaCl}$ composite, Mater. Lett. 211 (2018) 55-57, https://doi.org/10.1016/j.matlet. 2017.09.083.

[223] I. Induja, M. Sebastian, Microwave dielectric properties of mineral sillimanite obtained by conventional and cold sintering process, J. Eur. Ceram. Soc. 37 (2017) 2143-2147, https://doi.org/10.1016/j.jeurceramsoc.2017.01.007.

[224] D. Wang, S. Zhang, D. Zhou, K. Song, A. Feteira, Y. Vardaxoglou, W. Whittow, D. Cadman, I.M. Reaney, Temperature stable cold sintered $\left(\mathrm{Bi}_{0.95} \mathrm{Li}_{0.05}\right)\left(\mathrm{V}_{0.9} \mathrm{Mo}_{0.1}\right)$ $\mathrm{O}_{4}-\mathrm{Na}_{2} \mathrm{Mo}_{2} \mathrm{O}_{7}$ microwave dielectric composites, Materials 12 (9) (2019) 1370 , https://doi.org/10.3390/ma12091370.

[225] S. Venkatesan, M. ul Hassan, H.J. Ryu, Adsorption and immobilization of radioactive ionic-corrosion-products using magnetic hydroxyapatite and cold-sintering for nuclear waste management applications, J. Nucl. Mater. 514 (2019) 40-49, https://doi.org/10.1016/j.jnucmat.2018.11.026.

[226] M. ul Hassan, S. Iqbal, J.-I. Yun, H.J. Ryu, Immobilization of radioactive corrosion products by cold sintering of pure hydroxyapatite, J. Hazard. Mater. 374 (2019) 228-237, https://doi.org/10.1016/j.jhazmat.2019.04.038.

[227] M. ul Hassan, H.J. Ryu, Cold sintering and durability of iodate-substituted calcium hydroxyapatite (IO-HAp) for the immobilization of radioiodine, J. Nucl. Mater. 514 (2019) 84-89, https://doi.org/10.1016/j.jnucmat.2018.11.024.

[228] T. Charoonsuk, U. Sukkha, T. Kolodiazhnyi, N. Vittayakorn, Enhancing the densification of ceria ceramic at low temperature via the cold sintering assisted twostep sintering process, Ceram. Int. 44 (2018) S54-S57, https://doi.org/10.1016/j. ceramint.2018.08.253.

[229] H. Nakaya, M. Iwasaki, T.H. de Beauvoir, C.A. Randall, Applying cold sintering process to a proton electrolyte material: $\mathrm{CsH}_{2} \mathrm{PO}_{4}$, J. Eur. Ceram. Soc. 39 (2019) 396-401, https://doi.org/10.1016/j.jeurceramsoc.2018.09.001.

[230] J.-A. Liu, C.-H. Li, J.-J. Shan, J.-M. Wu, R.-F. Gui, Y.-S. Shi, Preparation of highdensity $\mathrm{InGaZnO}_{4}$ target by the assistance of cold sintering, Mater. Sci. Semicond. Process. 84 (2018) 17-23, https://doi.org/10.1016/j.mssp.2018.04.030.

[231] J. Guo, A.L. Baker, H. Guo, M. Lanagan, C.A. Randall, Cold sintering process: a new era for ceramic packaging and microwave device development, J. Am. Ceram. Soc. 100 (2017) 669-677, https://doi.org/10.1111/jace.14603.

[232] J. Ma, H. Li, H. Wang, C. Lin, X. Wu, T. Lin, X. Zheng, X. Yu, Composition, microstructure and electrical properties of $\mathrm{K}_{0.5} \mathrm{Na}_{0.5} \mathrm{NbO}_{3}$ ceramics fabricated by cold sintering assisted sintering, J. Eur. Ceram. Soc. 39 (2019) 986-993, https://doi. org/10.1016/j.jeurceramsoc.2018.11.044.

[233] W. Lee, C.K. Lyon, J.H. Seo, R. Lopez-Hallman, Y. Leng, C.Y. Wang, M.A. Hickner, C.A. Randall, E.D. Gomez, Ceramic-salt composite electrolytes from cold sintering, Adv. Funct. Mater. 29 (2019) 1807872, https://doi.org/10.1002/adfm. 201807872.

[234] Y. Liu, P. Liu, C. Hu, Low-temperature preparation and microwave dielectric properties of cold sintered $\mathrm{Li}_{2} \mathrm{Mg}_{3} \mathrm{TiO}_{6}$ nanocrystalline ceramics, Ceram. Int. 44 (2018) 21047-21052, https://doi.org/10.1016/j.ceramint.2018.08.141.

[235] S.S. Faouri, A. Mostaed, J.S. Dean, D. Wang, D.C. Sinclair, S. Zhang, W.G. Whittow, Y. Vardaxoglou, I.M. Reaney, High quality factor cold sintered $\mathrm{Li}_{2} \mathrm{MoO}_{4}-\mathrm{BaFe}_{12} \mathrm{O}_{19}$ composites for microwave applications, Acta Mater. 166 (2019) 202-207, https://doi.org/10.1016/j.actamat.2018.12.057.

[236] D. Zhou, L.-X. Pang, D.-W. Wang, I.M. Reaney, Novel water-assisting low firing $\mathrm{MoO}_{3}$ microwave dielectric ceramics, J. Eur. Ceram. Soc. 39 (2019) 2374-2378, https://doi.org/10.1016/j.jeurceramsoc.2019.01.052.

[237] S. Nayir, D.R. Waryoba, R. Rajagopalan, C. Arslan, C.A. Randall, Cold sintering of a covalently bonded $\mathrm{MoS}_{2}$ /graphite composite as a high capacity Li-Ion electrode, ChemNanoMat 4 (2018) 1088-1094, https://doi.org/10.1002/cnma.201800342.

[238] D. Wang, D. Zhou, S. Zhang, Y. Vardaxoglou, W.G. Whittow, D. Cadman, I.M. Reaney, Cold-sintered temperature stable $\mathrm{Na}_{0 .}{ }_{5} \mathrm{Bi}_{0 .}{ }_{5} \mathrm{MoO}_{4}-\mathrm{Li}_{2} \mathrm{MoO}_{4}$ microwave composite ceramics, ACS Sustain. Chem. Eng. 6 (2018) 2438-2444, https:// doi.org/10.1021/acssuschemeng.7b03889.

[239] H. Huang, J. Tang, J. Liu, Preparation of $\mathrm{Na}_{0}{ }_{5} \mathrm{Bi}_{0 .}{ }_{5} \mathrm{TiO}_{3}$ ceramics by hydrothermal-assisted cold sintering, Ceram. Int. 45 (2019) 6753-6758, https://doi org/10.1016/j.ceramint.2018.12.166.

[240] L. Li, W.B. Hong, S. Yang, H. Yan, X.M. Chen, Effects of water content during cold sintering process of $\mathrm{NaCl}$ ceramics, J. Alloys Compd. 787 (2019) 352-357, https:// doi.org/10.1016/j.jallcom.2019.02.112.

[241] H. Leng, J. Huang, J. Nie, J. Luo, Cold sintering and ionic conductivities of $\mathrm{Na}_{3.256} \mathrm{Mg}_{0.128} \mathrm{Zr}_{1.872} \mathrm{Si}_{2} \mathrm{PO}_{12}$ solid electrolytes, J. Power Sources 391 (2018) 170-179, https://doi.org/10.1016/j.jpowsour.2018.04.067.

[242] J.G.P. da Silva, M. Bram, A.M. Laptev, J. Gonzalez-Julian, Q. Ma, F. Tietz, O. Guillon, Sintering of a sodium-based NASICON electrolyte: a comparative study between cold, field assisted and conventional sintering methods, J. Eur. Ceram. Soc. 39 (2019) 2697-2702, https://doi.org/10.1016/j.jeurceramsoc.2019.03.023.

[243] D.S. Gyan, A. Dwivedi, Structural and electrical characterization of $\mathrm{NaNbO}_{3}-\mathrm{PVDF}$ nanocomposites fabricated using cold sintering synthesis route, J. Appl. Phys. 125 (2019) 024103, https://doi.org/10.1063/1.5046458.

[244] Q. Yu, Z. Jiang, L. Cong, T. Lu, B. Suleiman, G. Leng, Z. Wu, Y. Ding, Y. Li, A novel low-temperature fabrication approach of composite phase change materials for high temperature thermal energy storage, Appl. Energy. 237 (2019) 367-377, https://doi.org/10.1016/j.apenergy.2018.12.072.

[245] S.H. Bang, T.H. De Beauvoir, C.A. Randall, Densification of thermodynamically unstable tin monoxide using cold sintering process, J. Eur. Ceram. Soc. 39 (2019) 1230-1236, https://doi.org/10.1016/j.jeurceramsoc.2018.11.026.

[246] V. Medri, F. Servadei, R. Bendoni, A.N. Murri, A. Vaccari, E. Landi, Nano-tomacroporous $\mathrm{TiO}_{2}$ (anatase) by cold sintering process, J. Eur. Ceram. Soc. 39
(2019) 2453-2462, https://doi.org/10.1016/j.jeurceramsoc.2019.02.047.

[247] J. Guo, H. Guo, D.S.B. Heidary, S. Funahashi, C.A. Randall, Semiconducting properties of cold sintered $\mathrm{V}_{2} \mathrm{O}_{5}$ ceramics and co-sintered $\mathrm{V}_{2} \mathrm{O}_{5}$-PEDOT:PSS composites, J. Eur. Ceram. Soc. 37 (2017) 1529-1534, https://doi.org/10.1016/j. jeurceramsoc.2016.11.021.

[248] D.S.B. Heidary, J. Guo, J.-H. Seo, H. Guo, R. Rajagopalan, C.A. Randall, Microstructures and electrical properties of $\mathrm{V}_{2} \mathrm{O}_{5}$ and carbon-nanofiber composites fabricated by cold sintering process, Jpn. J. Appl. Phys. 57 (2018) 025702, , https://doi.org/10.7567/JJAP.57.025702.

[249] Y. Zhao, S.S. Berbano, L. Gao, K. Wang, J. Guo, K. Tsuji, J. Wang, C.A. Randall, Cold-sintered $\mathrm{V}_{2} \mathrm{O}_{5}$-PEDOT: PSS nanocomposites for negative temperature coefficient materials, J. Eur. Ceram. Soc. 39 (2019) 1257-1262, https://doi.org/10. 1016/j.jeurceramsoc.2018.10.018.

[250] J. Gonzalez-Julian, K. Neuhaus, M. Bernemann, J.P. da Silva, A. Laptev, M. Bram, O. Guillon, Unveiling the mechanisms of cold sintering of $\mathrm{ZnO}$ at $250^{\circ} \mathrm{C}$ by varying applied stress and characterizing grain boundaries by kelvin probe force microscopy, Acta Mater. 144 (2018) 116-128, https://doi.org/10.1016/j.actamat. 2017.10.055.

[251] X. Kang, R. Floyd, S. Lowum, M. Cabral, E. Dickey, J.P. Maria, Mechanism studies of hydrothermal cold sintering of zinc oxide at near room temperature, J. Am. Ceram. Soc. 102 (2019) 4459-4469, https://doi.org/10.1111/jace.16340.

[252] Y. Jing, N. Luo, S. Wu, K. Han, X. Wang, L. Miao, Y. Wei, Remarkably improved electrical conductivity of $\mathrm{ZnO}$ ceramics by cold sintering and post-heat-treatment, Ceram. Int. 44 (2018) 20570-20574, https://doi.org/10.1016/j.ceramint.2018. 07.192.

[253] S. Lowum, R. Floyd, R. Bermejo, J.-P. Maria, Mechanical strength of cold-sintered zinc oxide under biaxial bending, J. Mater. Sci. 54 (2019) 4518-4522, https://doi. org/10.1007/s10853-018-3173-8.

[254] J. Guo, B. Legum, B. Anasori, K. Wang, P. Lelyukh, Y. Gogotsi, C.A. Randall, Cold sintered ceramic nanocomposites of 2D MXene and zinc oxide, Adv. Mater. 30 (2018) 1801846, https://doi.org/10.1002/adma.201801846.

[255] X. Zhao, J. Guo, K. Wang, T. Herisson De Beauvoir, B. Li, C.A. Randall, Introducing a ZnO-PTFE (polymer) nanocomposite varistor via the cold sintering process, Adv. Eng. Mater. (2018) 1700902, https://doi.org/10.1002/adem.201700902.

[256] J. Guo, X. Zhao, T. Herisson De Beauvoir, J.H. Seo, S.S. Berbano, A.L. Baker, C. Azina, C.A. Randall, Recent progress in applications of the cold sintering process for ceramic-polymer composites, Adv. Funct. Mater. (2018) 1801724 https://doi.org/10.1002/adfm.201801724.

[257] W.T. Chen, A.E. Gurdal, S. Tuncdemir, J. Guo, H. Guo, C.A. Randall, Considering the possibility of bonding utilizing cold sintering for ceramic adhesives, J. Am. Ceram. Soc. 100 (2017) 5421-5432, https://doi.org/10.1111/jace.15098.

[258] S. Hashimoto, W. Shimoda, H. Takeda, Y. Daiko, S. Honda, Y. Iwamoto, Fabrication of slaked lime compacts (plasters) with high compressive strength using a warm press method, Constr. Build. Mater. 110 (2016) 65-69, https://doi. org/10.1016/j.conbuildmat.2016.02.009.

[259] S. Hashimoto, K. Kubota, K. Ando, Y. Diko, S. Honda, Y. Iwamoto, Effect of grinding treatment of fly ash on compressive strength of hardened geopolymers using warm press method, MATEC Web of Conferences, EDP Sciences, 2017, p. 01120 .

[260] S. Hashimoto, S. Kusawake, Y. Daiko, S. Honda, Y. Iwamoto, Fabrication of pure phase calcium carbonate hardened bodies as a means of creating novel geomimetic ceramics, Constr. Build. Mater. 135 (2017) 405-410, https://doi.org/10.1016/j. conbuildmat.2016.12.211.

[261] S. Hashimoto, K. Kubota, K. Ando, M. Tsutani, Y. Diko, S. Honda, Y. Iwamoto, Fabrication of $\mathrm{SiC}$ hardened bodies with geopolymer binders using a warm press method, AIP Conference Proceedings, AIP Publishing, 2017, p. 020011.

[262] R.E. Riman, V. Atakan, Method of hydrothermal liquid phase sintering of ceramic materials and products derived therefrom, US Patent \#8,313,802 B2, November 20, 2012; US Patent No. US 8,709,960 B2, April 29, 2014.

[263] K. Byrappa, M. Yoshimura, 10 - Hydrothermal Processing of Materials, in: K. Byrappa, M. Yoshimura (Eds.), Handbook of Hydrothermal Technology, William Andrew Publishing, Norwich, NY, 2001, p. 754-II.

[264] M. Kaneko, Solidification of ion-exchange resins by hydrothermal hot-pressing, J. Mater. Sci. Lett. 12 (1993) 591-593, https://doi.org/10.1007/BF00278334.

[265] A. Irie, J. Ohno, T. Hayakawa, H. Kido, T. Fukushima, Transparent film formation of DNA/cationic polymer complexes by hydrothermal hot pressing: observation of cell culture on films and biodegradation of films in vivo, J. Hard Tissue Biol. 22 (2013) 105-114, https://doi.org/10.2485/jhtb.22.105.

[266] Y. Inoue, M. Kawaguchi, I. Masui, H. Horibe, T. Rikimaru, M. Kuroki, Y. Katsumata, N. Mori, T. Hayakawa, T. Fukushima, Biological and chemical assessment of DNA/chitosan complex film, J. Hard Tissue Biol. 23 (2014) 399-406, https://doi.org/10.2485/jhtb.23.399.

[267] Z. Di, F. Yang, Y. Cao, F. Cheng, K. Zhang, Properties of binderless coal slime briquette via hydrothermal hot pressing dewatering, Energ. Source Part A 39 (2017) 1222-1227, https://doi.org/10.1080/15567036.2017.1318190.

[268] N. Yamasaki, Development of recycling technologies, and functional material formation by hydrothermal processes, J. Ceram. Soc. Jpn. 111 (2003) 709-715, https://doi.org/10.2109/jcersj.111.709.

[269] N. Yamasaki, Y. Yamasaki, K. Tohji, N. Tsuchiya, T. Hashida, K. Ioku, Hydrothermal dynamics on environmental problems using the aspect of earth science, J. Mater. Sci. 41 (2006) 1599-1604, https://doi.org/10.1007/s10853006-4654-8.

[270] A. Ndayishimiye, M.Y. Sengul, S.H. Bang, K. Tsuji, K. Takashima, T.H. de Beauvoir, D. Denux, J.-M. Thibaud, A.C.T. van Duin, C. Elissalde, G. Goglio, C.A. Randall, Comparing hydrothermal sintering and cold sintering process: mechanisms, microstructure, kinetics and chemistry, J. Eur. Ceram. Soc. (2019), 
https://doi.org/10.1016/j.jeurceramsoc.2019.11.049.

[271] T. Ibn-Mohammed, C.A. Randall, K. Mustapha, J. Guo, J. Walker, S. Berbano, S. Koh, D. Wang, D. Sinclair, I. Reaney, Decarbonising ceramic manufacturing: techno-economic analysis of energy efficient sintering technologies in the functional materials sector, J. Eur. Ceram. Soc. 39 (2019) 5213-5235, https://doi.org/

10.1016/j.jeurceramsoc.2019.08.011.
[272] M. Biesuz, G. Taveri, A.I. Duff, E. Olevsky, D. Zhu, C. Hu, S. Grasso, A theoretical analysis of cold sintering, Adv. Appl. Ceram. (2019) 1-15, https://doi.org/10. 1080/17436753.2019.1692173.

[273] S. Grasso, M. Biesuz, L. Zoli, G. Taveri, A.I. Duff, D. Ke, A. Jiang, M.J. Reece, A review of cold sintering processes, Adv. Appl. Ceram. (2020) 1-29, https://doi. org/10.1080/17436753.2019.1706825. 